Prepared in cooperation with the National Park Service, Yellowstone National Park, and Earthscope Plate Boundary Observatory

\title{
Geologic and Geochemical Results from Boreholes Drilled in Yellowstone National Park, Wyoming, 2007 and 2008
}

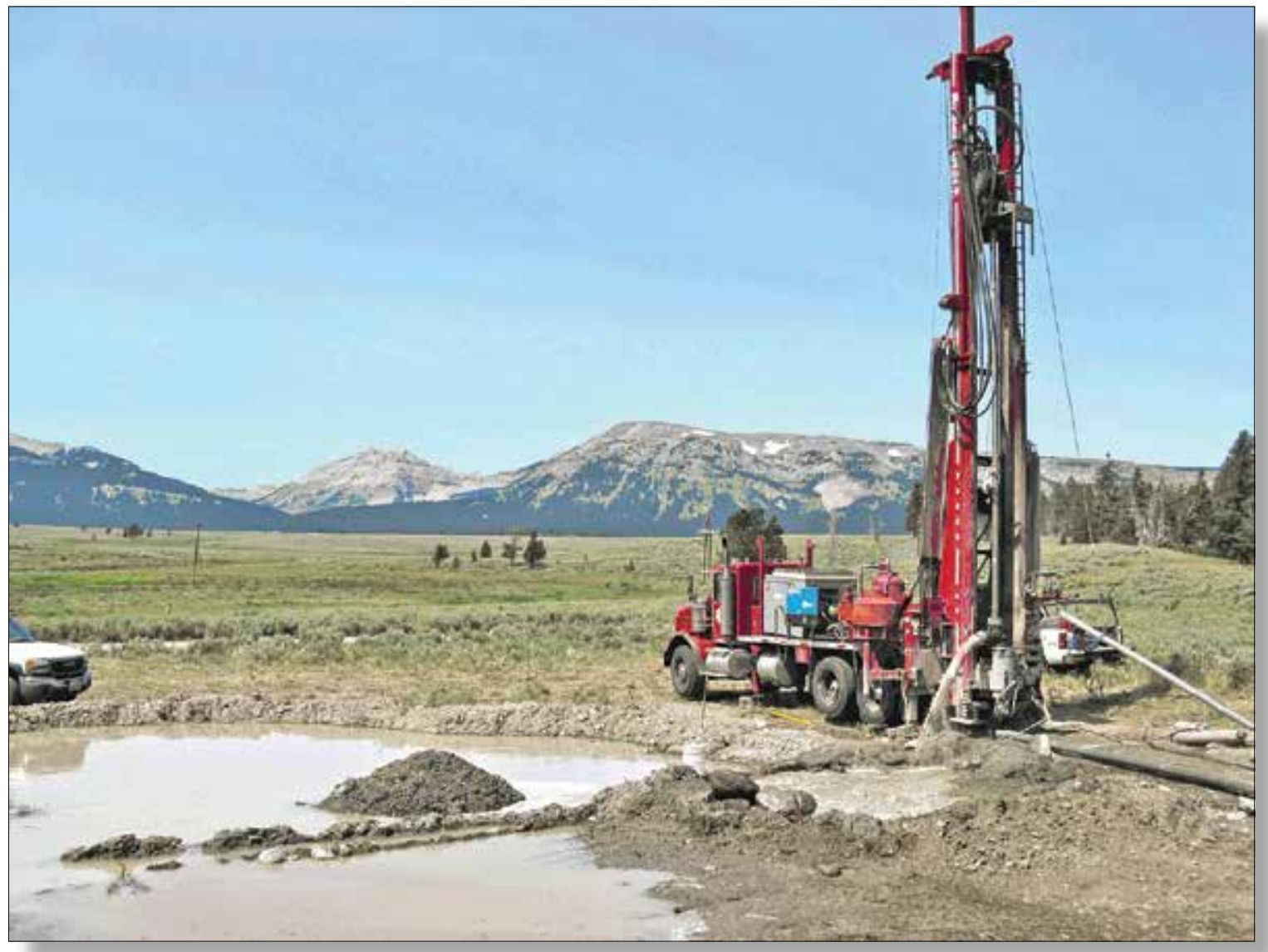

Open-File Report 2016-1028 
Cover photograph: The B945 Panther Creek borehole, located south of Mammoth Hot Springs in Yellowstone National Park, was one of seven Earthscope Plate Boundary Observatory boreholes drilled during 2007 and 2008 for the purpose of installing volcano monitoring instrumentation. View looking west toward the Gallatin Mountains. Photograph taken by Henry Heasler, August 11, 2008. 


\section{Geologic and Geochemical Results from Boreholes Drilled in Yellowstone National Park, Wyoming, 2007 and 2008}

By Cheryl Jaworowski, David Susong, Henry Heasler, David Mencin, Wade Johnson, Rick Conrey, and Jennipher Von Stauffenberg

Prepared in cooperation with the National Park Service, Yellowstone National Park, and Earthscope Plate Boundary Observatory

Open-File Report 2016-1028 


\title{
U.S. Department of the Interior SALLY JEWELL, Secretary
}

\section{U.S. Geological Survey Suzette M. Kimball, Director}

\author{
U.S. Geological Survey, Reston, Virginia: 2016
}

For more information on the USGS - the Federal source for science about the Earth, its natural and living resources, natural hazards, and the environment-visit http://www.usgs.gov or call 1-888-ASK-USGS.

For an overview of USGS information products, including maps, imagery, and publications, visit http://store.usgs.gov.

Any use of trade, firm, or product names is for descriptive purposes only and does not imply endorsement by the U.S. Government.

Although this information product, for the most part, is in the public domain, it also may contain copyrighted materials as noted in the text. Permission to reproduce copyrighted items must be secured from the copyright owner.

Suggested citation:

Jaworowski, C., Susong, D., Heasler, H., Mencin, D., Johnson, W., Conrey, R., and Von Stauffenberg, J., 2016,

Geologic and geochemical results from boreholes drilled in Yellowstone National Park, Wyoming, 2007 and 2008:

U.S. Geological Survey Open-File Report 2016-1028, 39 p. http://dx.doi.org/10.3133/ofr20161028

ISSN 2331-1258 (online) 


\section{Contents}

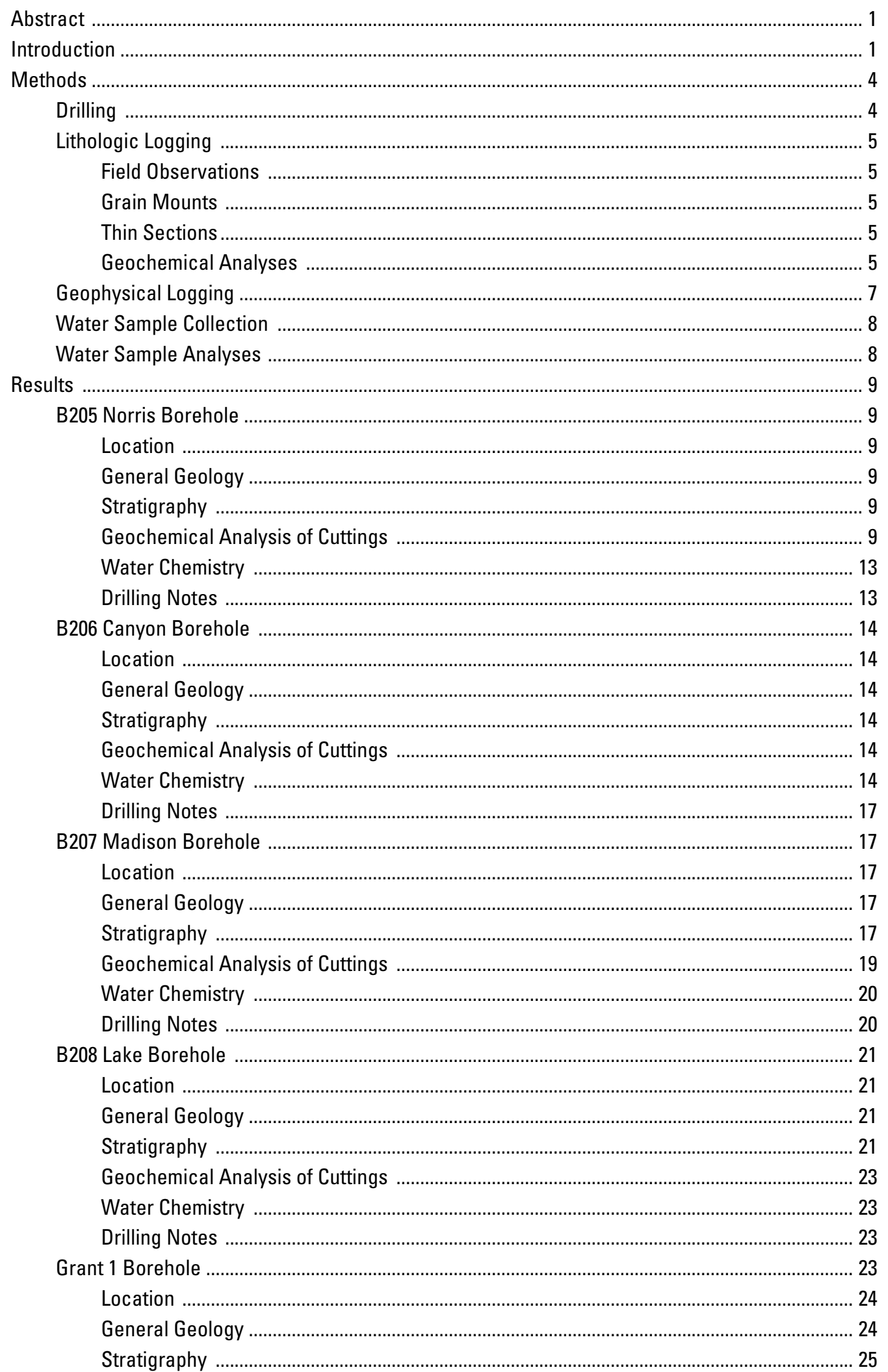




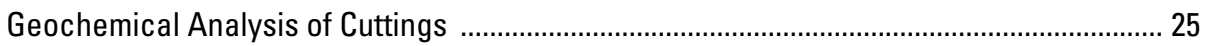

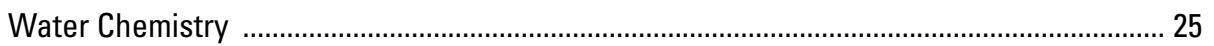

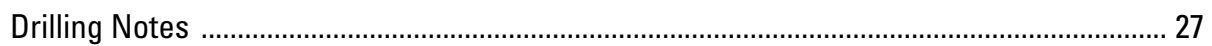

B944 Grant Borehole .............................................................................................................. 28

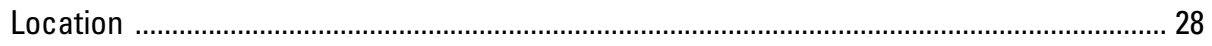

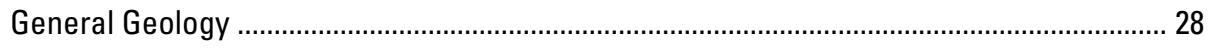

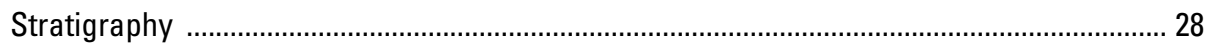

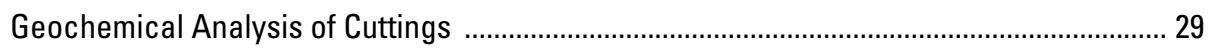

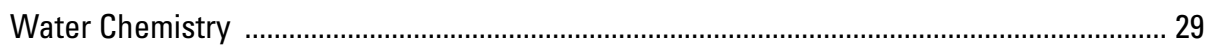

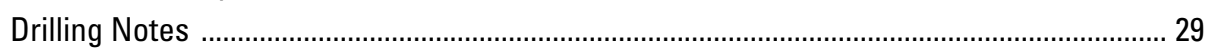

B945 Panther Creek Borehole ................................................................................................ 30

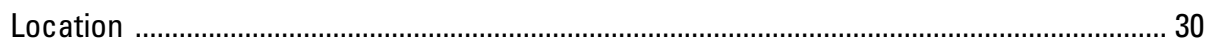

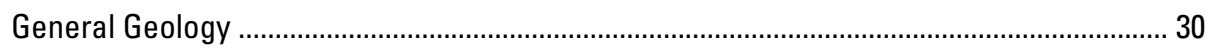

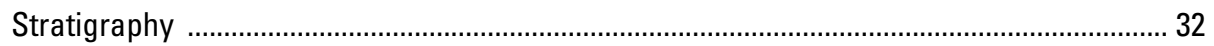

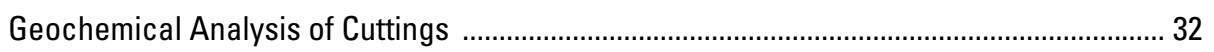

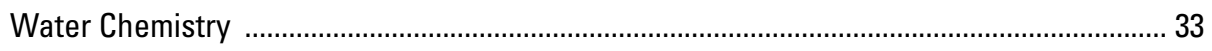

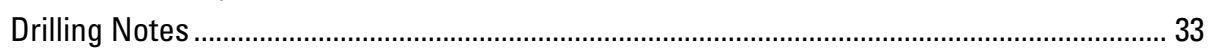

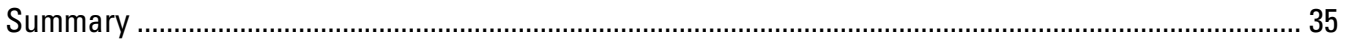

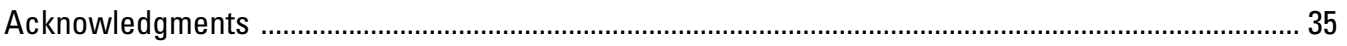

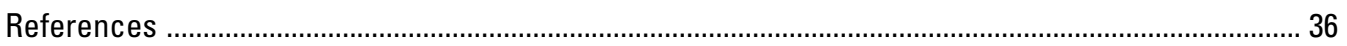

Appendix 1. Major and rare earth element analyses fPSselected samples of cuttings from boreholes drilled in 2007 and 2008 and fPSreference samples from selected volcanic units in Yellowstone National Park, Wyoming ............................................. 39

Appendix 2. Water-quality analyses for samples collected during the drilling of boreholes in 2007 and 2008 in Yellowstone National Park, Wyoming ............................................... 39

\section{Figures}

1. Map showing location of boreholes drilled for installation of strainmeters in 2007 and 2008, and the boundary of the Yellowstone caldera, Yellowstone National Park, Wyoming ............... 2

2. Schematic diagram showing typical borehole strainmeter installation ....................................... 3

3. Photomicrographs of cuttings from a glassy rhyolite flow showing quartz and feldspar phenocrysts at 30-foot depth in the B205 Norris borehole, a welded tuff showing quartz and feldspar phenocrysts at 495-foot depth in the B205 Norris borehole, a rhyolite showing perlitic texture and flow banding at 100-foot depth in the B206 Canyon borehole, a tuffaceous sediment at 800-foot depth in the B208 Lake borehole, a vitrophyric zone at 105 -foot depth in the B944 Grant borehole, and a sanidine phenocryst showing simple twinning within a chaotic zone at 260-foot depth in the B944 borehole.

4. Photomicrographs of cuttings recovered during drilling of the B205 Norris borehole at 300-foot depth, and B945 Panther Creek borehole at 450-foot depth

5. Map showing bedrock geology in the vicinity of the B205 Norris borehole, Yellowstone National Park, Wyoming

6. Graph showing rare earth element chemistry for selected depths in the upper part of the B205 Norris borehole, and for a reference sample from the Gibbon River flow

7. Graph showing rare earth element chemistry for selected depths in the lower part of the B205 Norris borehole and for a reference sample from the Lava Creek Tuff 
8. Graph showing concentrations of zirconium versus niobium for B205 Norris borehole samples, reference samples of the Lava Creek Tuff from this study, a sample from Bindeman and Valley (2001), a sample from Christiansen (2001), and for samples from Von Stauffenberg (2015)

9. Map showing bedrock geology in the vicinity of the B206 Canyon borehole, Yellowstone National Park, Wyoming

10. Graph showing rare earth element chemistry for selected depths in the B206 Canyon borehole and for reference samples from the Hayden Valley flow and the Canyon flow

11. Map showing bedrock geology in the vicinity of the B207 Madison borehole, Yellowstone National Park, Wyoming

12. Graph showing rare earth element chemistry for selected depths in the upper part of the B207 Madison borehole and for a reference sample from the Nez Perce Creek flow

13. Graph showing rare earth element chemistry for selected depths in the lower part of the B207 Madison borehole and for a reference sample from the Lava Creek Tuff in Gibbon Canyon

14. Graph showing concentrations of zirconium versus niobium for lower B207 Madison borehole samples, reference samples of the Lava Creek Tuff from this study, a sample from Christiansen (2001), a sample from Bindeman and Valley (2001), and for samples from Von Stauffenberg (2015)

15. Map showing bedrock geology in the vicinity of the B208 Lake borehole, Yellowstone National Park, Wyoming

16. Graph showing rare earth element chemistry for selected depths in the upper part of the B208 Lake borehole and for reference samples from the West Thumb flow and Tuff of Bluff Point

17. Graph showing rare earth element chemistry for selected depths in the lower part of the B208 Lake borehole and for reference samples from the West Thumb flow and Tuff of Bluff Point

18. Map showing bedrock geology in the vicinity of the Grant 1 and B944 Grant boreholes, Yellowstone National Park, Wyoming

19. Graph showing rare earth element chemistry for selected depths in the Grant 1 borehole and for reference samples from the Tuff of Bluff Point (this study), and the Tuff of Bluff Point from Pritchard (2011)

20. Graph showing rare earth element chemistry for selected depths in the upper part of the B944 Grant borehole and for a reference sample from the Tuff of Bluff Point 28

21. Graph showing rare earth element chemistry for selected depths in the lower part of the B944 Grant borehole and for reference samples from the Tuff of Bluff Point and Dry Creek flow

22. Map showing bedrock geology in the vicinity of the B945 Panther Creek borehole, Yellowstone National Park, Wyoming

23. Graph showing rare earth element chemistry for selected depths in the B945 Panther Creek borehole and for selected reference samples from the Panther Creek vent, the Swan Lake Flat Basalt, and the Gardner River and Grizzly Lake rhyolite flows

24. Graph showing concentrations, in weight percent, of iron oxide versus silicon dioxide for B945 Panther Creek borehole samples and samples from the Panther Creek vent, and reference samples from Pritchard (2011) for Gardner River rhyolites, Gardner River basalts, Grizzly Lake rhyolites, Grizzly Lake basalts, and Swan Lake Flat basalts 


\section{Tables}

1. Borehole location, drilling dates, and depth of boreholes drilled in 2007 and 2008 in Yellowstone National Park, Wyoming

2. Location of reference samples collected from Yellowstone volcanic units for rare earth element analysis, Yellowstone National Park, Wyoming

3. General stratigraphy and lithology for the B205 Norris borehole, Yellowstone National Park, Wyoming 11

4. Major water production zones and temperature in the B205 Norris borehole, Yellowstone National Park, Wyoming ....................................................................................................... 13

5. General stratigraphy and lithology for the B206 Canyon borehole, Yellowstone National Park, Wyoming

6. Major water production zone in the B206 Canyon borehole, Yellowstone National Park, Wyoming

7. General stratigraphy and lithology for the B207 Madison borehole, Yellowstone National Park, Wyoming

8. Major water production zones and temperature in the B207 Madison borehole, Yellowstone National Park, Wyoming

9. General stratigraphy and lithology for the B208 Lake borehole, Yellowstone National Park, Wyoming

10. Major water production zones and temperature in the B208 Lake borehole, Yellowstone National Park, Wyoming

11. General stratigraphy and lithology for the Grant 1 borehole, Yellowstone National Park, Wyoming

12. General stratigraphy and lithology for the B944 Grant borehole, Yellowstone National Park, Wyoming

13. Major water production zones and temperature in the B944 Grant borehole, Yellowstone National Park, Wyoming

14. General stratigraphy and lithology for the B945 Panther Creek borehole, Yellowstone National Park, Wyoming

15. Major water production zones and temperature in the B945 Panther Creek borehole, Yellowstone National Park, Wyoming

A1-1. Rare earth element chemistry for cuttings samples from Earthscope Plate Boundary Observatory boreholes, Yellowstone National Park, Wyoming

A1-2. Rare earth element chemistry for reference samples from mapped geologic units, Yellowstone National Park, Wyoming

A1-3. Major- and trace-element chemistry for cuttings samples from Earthscope Plate Boundary Observatory boreholes, Yellowstone National Park, Wyoming

A1-4. Major- and trace-element chemistry for reference samples from mapped geologic units, Yellowstone National Park, Wyoming

A2-1. Field measurements and results of chemical analysis for major ions, trace elements, stable isotopes, and tritium for water samples collected from boreholes and selected other sites, 2007 and 2008, Yellowstone National Park, Wyoming 


\section{Conversion Factors}

Inch/Pound to SI

\begin{tabular}{|c|c|c|}
\hline Multiply & By & To obtain \\
\hline \multicolumn{3}{|c|}{ Length } \\
\hline inch (in.) & 2.54 & centimeter $(\mathrm{cm})$ \\
\hline inch (in.) & 25.4 & millimeter (mm) \\
\hline foot $(\mathrm{ft})$ & 0.3048 & meter $(\mathrm{m})$ \\
\hline mile (mi) & 1.609 & kilometer $(\mathrm{km})$ \\
\hline \multicolumn{3}{|c|}{ Volume } \\
\hline gallon (gal) & 3.785 & liter $(\mathrm{L})$ \\
\hline \multicolumn{3}{|c|}{ Flow rate } \\
\hline gallon per minute (gal/min) & 0.06309 & liter per second $(\mathrm{L} / \mathrm{s})$ \\
\hline
\end{tabular}

Temperature in degrees Celsius $\left({ }^{\circ} \mathrm{C}\right)$ can be converted to degrees Fahrenheit $\left({ }^{\circ} \mathrm{F}\right)$ as follows:

$$
{ }^{\circ} \mathrm{F}=\left(1.8 \times{ }^{\circ} \mathrm{C}\right)+32
$$

Temperature in degrees Fahrenheit $\left({ }^{\circ} \mathrm{F}\right) \mathrm{can}$ be converted to degrees Celsius $\left({ }^{\circ} \mathrm{C}\right)$ as follows:

$$
{ }^{\circ} \mathrm{C}=\left({ }^{\circ} \mathrm{F}-32\right) / 1.8 \text {. }
$$

\section{Datums}

Vertical coordinate information is referenced to the North American Vertical Datum of 1988 (NAVD 88).

Horizontal coordinate information is referenced to the North American Datum of 1983 (NAD 83).

Altitude, as used in this report, refers to distance above the vertical datum.

\section{Water-Quality Units}

Specific conductance is given in microsiemens per centimeter at 25 degrees Celsius $\left(\mu \mathrm{S} / \mathrm{cm}\right.$ at $\left.25^{\circ} \mathrm{C}\right)$.

Concentrations of chemical constituents in water are given in either milligrams per liter $(\mathrm{mg} / \mathrm{L})$ or micrograms per liter $(\mu \mathrm{g} / \mathrm{L})$.

Concentrations of chemical constituents in drill cuttings samples are given in parts per million (ppm).

Concentrations of stable isotopes in water are expressed in permil (per thousand, \%o) notation. 


\title{
Geologic and Geochemical Results from Boreholes Drilled in Yellowstone National Park, Wyoming, 2007 and 2008
}

\author{
By Cheryl Jaworowski', David Susong ${ }^{2}$, Henry Heasler ${ }^{1}$, David Mencin ${ }^{3}$, Wade Johnson ${ }^{3}$, Rick Conrey ${ }^{4}$, and \\ Jennipher Von Stauffenberg ${ }^{4}$
}

\section{Abstract}

Between 2007 and 2008, seven Earthscope Plate Boundary Observatory (PBO) boreholes ranging in depth from about 200 to 800 feet deep were drilled in and adjacent to the Yellowstone caldera in Yellowstone National Park, for the purpose of installing volcano monitoring instrumentation. Five of the seven boreholes were equipped with strainmeters, downhole seismometers, and tiltmeters. Data collected during drilling included field observations of drill cuttings, stratigraphy within the boreholes, water temperature, and water and drill cuttings samples from selected depths.

Six of the seven boreholes encountered rhyolite lavas and tuffs. The rhyolite lavas compose the Canyon flow, the Gardner River flow, the Gibbon River flow, the Hayden Valley flow, the Nez Perce Creek flow, and the West Thumb flow. Boreholes also penetrated a vertical sequence through the Lava Creek Tuff and the Tuff of Bluff Point. In addition, one borehole Z DVldrilled through a Swan Lake Flat Basalt sequence and terminated in a rhyolite lava flow.

After drilling the seven PBO boreholes, cuttings were examined and selected for preparation of grain mounts, thin sections, and geochemical analysis. Major ions and trace elements (including rare earth elements) of selected cuttings were determined by $\mathrm{x}$-ray fluorescence (XRF) and inductively coupled plasma-mass spectrometry (ICP-MS); the ICP-MS provided more precise trace-element analysis than XRF. A preliminary interpretation of the results of geochemical analyses generally shows a correlation between borehole cuttings and previously mapped geology. The geochemical data and borehole stratigraphy presented in this report provide a foundation for future petrologic, geochemical, and geophysical studies.

${ }^{1}$ Yellowstone National Park, Wyoming, ${ }^{2}$ U.S. Geological Survey, Salt Lake City, Utah, ${ }^{3}$ Plate Boundary Observatory, Boulder, Colorado, ${ }^{4}$ Washington State University GeoAnalytical Laboratory, Pullman, Washington.

\section{Introduction}

Yellowstone National Park (YNP) was created in 1872 in a remote region of the country before Montana, Idaho, or Wyoming were states and prior to any permanent human settlement in the park. This decision protected the area in its natural condition with limited infrastructure development. As a result of this early protection effort, very limited information exists about the geology and water resources in the shallow subsurface (1,000 feet (ft) below land surface) because there have been few wells and boreholes drilled in the park. In 1929 and 1930, Fenner (1936) drilled the first research boreholes in Yellowstone's Upper and Norris Geyser Basins. The U.S. Geological Survey (USGS) in 1967 and 1968 drilled 13 research boreholes within and near hydrothermal areas in the park (White and others, 1975). The depths of the holes ranged from 215 to $1,088 \mathrm{ft}$. These research holes were critical in the development of conceptual models of fluid flow and geochemistry for the Yellowstone hydrothermal system (White and others, 1975). Cox (1973) drilled other shallow wells in the park as part of a water resources study that investigated alluvial aquifers for water supplies within the Park's developed areas.

In 2007 and 2008, seven boreholes were drilled in YNP (fig. 1) as part of the National Science Foundation funded Earthscope Plate Boundary Observatory (PBO) that investigates deformation across the boundary between the Pacific and North American plates in the western United States (http://www.earthscope.org/observatories, accessed on February 20,2014). The observatory consists of networks of Global Positioning System (GPS) receivers and strainmeters. GPS instruments measure millimeter-scale ground movement on time scales of days to decades. Borehole strainmeters measure strain by sensing changes in the shape of an instrument cemented into rock. These instruments monitor deformation associated with earthquakes and volcanic eruptions and are installed in Yellowstone to measure ground deformation in and adjacent to the 639,000-year old Yellowstone caldera (fig. 1). Five of the seven boreholes drilled in Yellowstone were equipped with strainmeters, downhole seismometers and tiltmeters. A typical completion and instrument installation in a borehole is shown in figure 2 (ftp://borehole.unavco.org/pub/ borehole/B207/, accessed on March 9, 2014). 


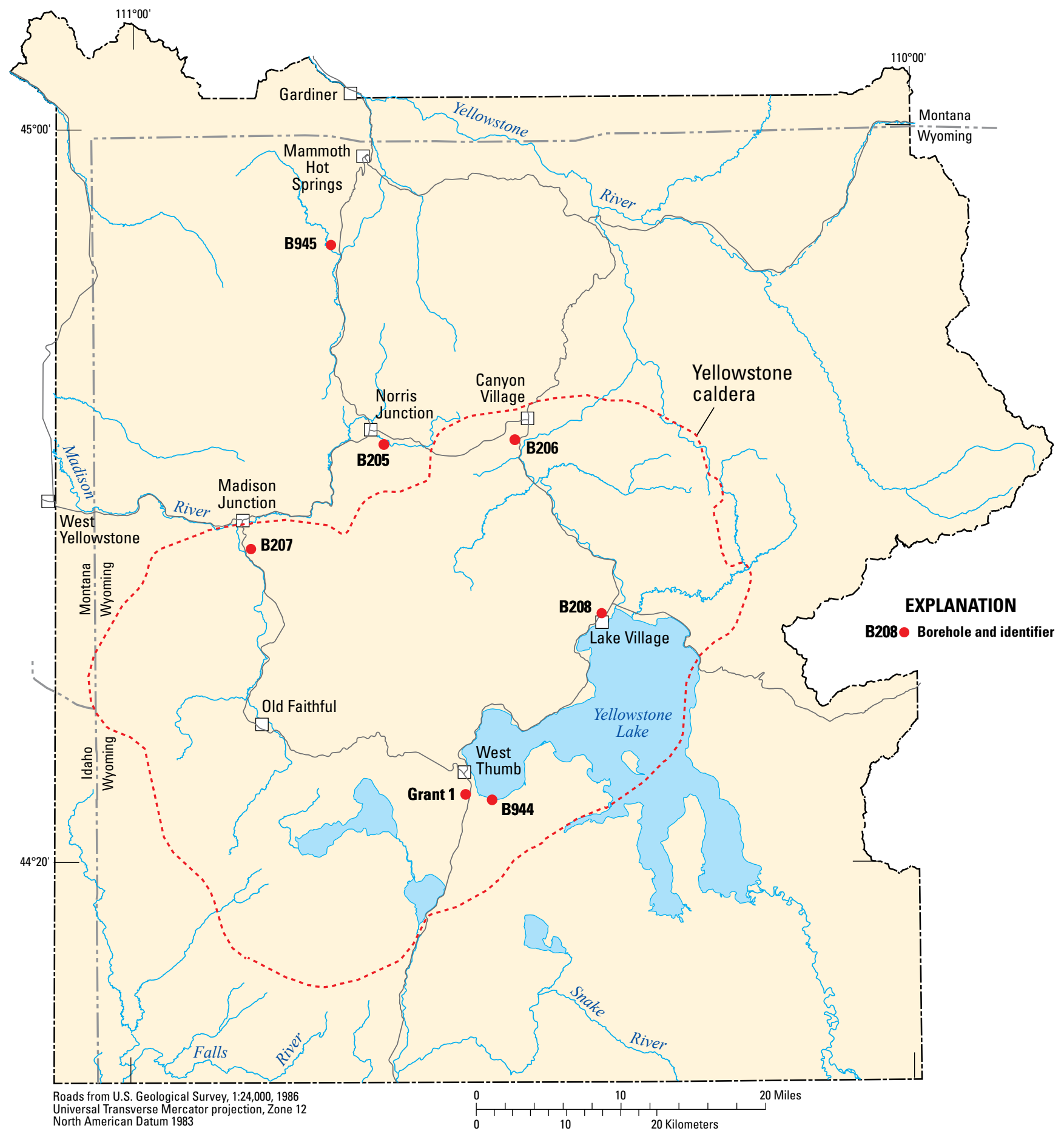

Figure 1. Location of boreholes drilled for installation of strainmeters in 2007 and 2008, and the boundary of the Yellowstone caldera, Yellowstone National Park, Wyoming. 


\section{B207 Madison borehole}

$44.619 / 110.8485$, latitude/longitude, in decimal degrees 7,160 feet, elevation

5 feet

fill

rhyolite flow

Not to scale

Cables not shown All depths relative to top of casing

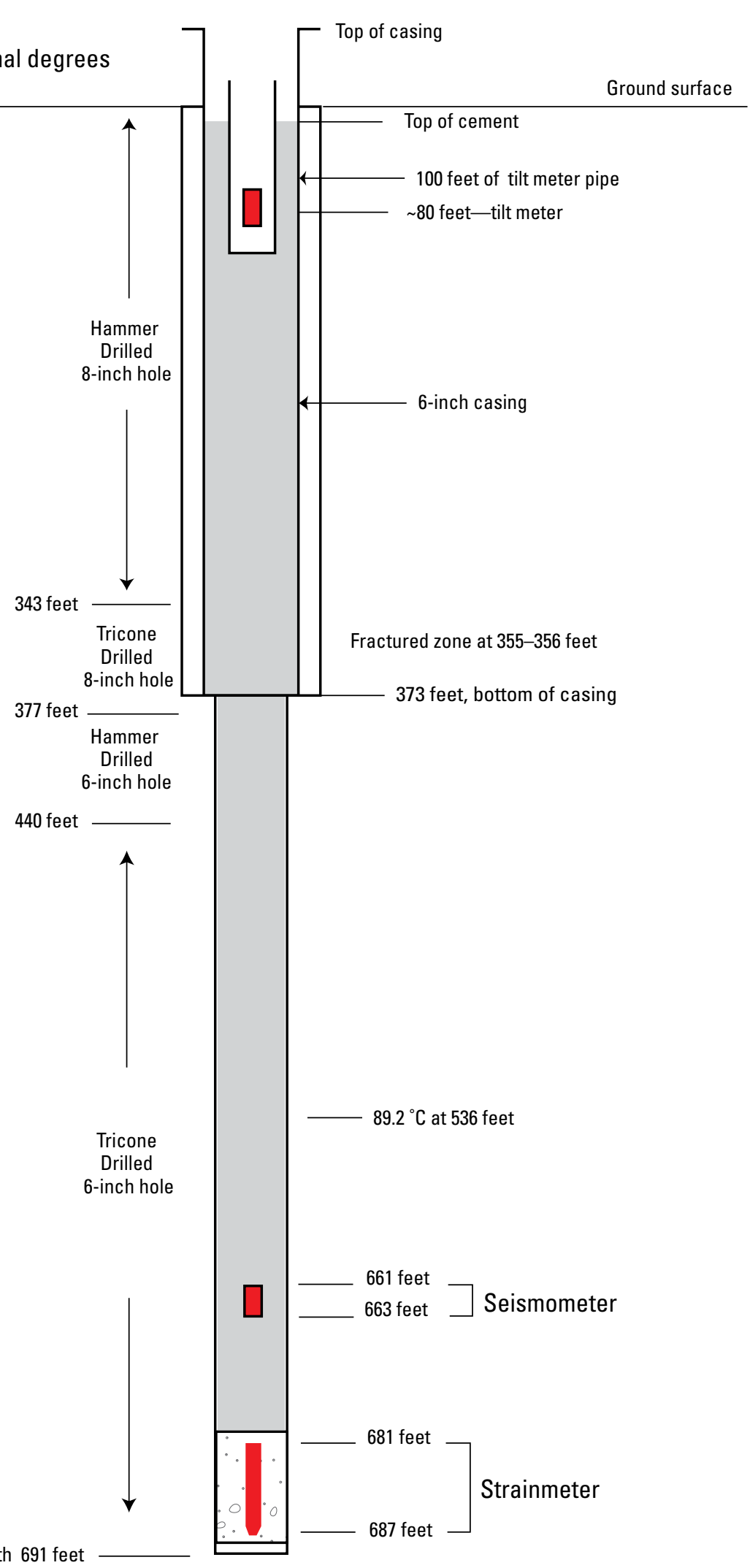

Total depth 691 feet

Figure 2. Typical borehole strainmeter installation in Yellowstone National Park, Wyoming. 
The purpose of this report is to present data collected during the drilling of the PBO boreholes including drilling observations, stratigraphy from field examination of cuttings, geochemical analyses of cuttings and preliminary interpretations of the data, and water-quality analyses from selected depths. The report focuses on data collected during the drilling or immediately following the drilling of the boreholes and provides examples of geochemical analyses for each borehole. As an initial investigation, this report does not present a detailed description of units nor an exhaustive geochemical or petrologic analysis. Instead, this report provides a foundation for future studies. The data from the boreholes drilled as part of the PBO network installation add to the library of information about the shallow subsurface stratigraphy, fluid flow, and chemistry.

The locations of PBO boreholes in Yellowstone (fig. 1), drilling dates, and depths are listed in table 1 . All the boreholes occur near existing park facilities where power was accessible and disturbance in the park could be minimized. During the drilling of each borehole, cuttings and water-quality samples were collected, and temperature and geophysical logs were run.

\section{Methods}

Various types of data were collected during the drilling of the seven boreholes for installation of the borehole strainmeters. Lithologic descriptions from field examination of cuttings, temperature logs, geophysical logs, and samples for geochemical analyses of cuttings and water-quality analyses from selected depths were obtained during the drilling or following the drilling of the boreholes. The following sections discuss the methods used to collect and analyze these data.

\section{Drilling}

The boreholes were drilled with an air rotary, water well drilling rig. Typically, an 8-inch (in.) hole was drilled to a depth of about $350 \mathrm{ft}$ and 6-in. casing was installed in the hole. Below this depth, the hole size was reduced to 6 in. and was not cased. Cuttings were collected during drilling. Water samples and temperature and geophysical logs were obtained periodically at increasing depths as drilling proceeded. When the final depth of the hole was reached, the downhole instrumentation was installed at selected depths and the holes were grouted with cement.

Drilling in YNP requires caution and additional monitoring for health and safety and for protection of Yellowstone's hydrothermal resources. For safety, a blow-out preventer was available for all boreholes and crews were trained in its use. For each hole, a plan for containment of high-pressure, high-temperature steam was in place. The plan specifically addressed how to vent steam away from the drilling platform so that the driller could safely inject, at a high rate, large quantities of cold water. Contingency plans for cementing and plugging a borehole also were created. For health and safety as well as protection of hydrothermal resources, it was necessary to determine if hydrothermal fluids were encountered during drilling. The following monitoring was required: (1) measurement of the temperature of the discharged drilling fluid every $10 \mathrm{ft}$ of drilling, and (2) collection of water samples for analysis of field parameters when there was a significant change in water production from the borehole. After collection of a water sample, temperature, specific conductance, and $\mathrm{pH}$ were measured and recorded. Every evening, the drill rods were removed from the well and the borehole was allowed to thermally equilibrate overnight. Before drilling began in the morning, a precision temperature profile of the borehole was obtained. The presence of geothermal gases, carbon dioxide, and hydrogen sulfide was checked occasionally both in the discharge line and through the top of the kelly bushing. These data along with fluid production (rate and characteristics), lithologic descriptions of cuttings (boundaries of lava flows and tuffs, rock properties), and well logs (fracture and other characteristics) were analyzed continuously during drilling to assess if hydrothermal fluids were present in the borehole.

Detailed notes of field observations during drilling were compiled including characterization of discharge from the rig (color, estimated volume, temperature), drilling characteristics (hardness/softness, loss of circulation, unusual cuttings), and casing installation and bit changes. These notes are available in electronic form on the PBO ftp site (ftp://borehole. unavco.org/pub/borehole/, accessed on March 9, 2014) where geophysical data for all logged borehole strainmeters are also available. In addition, paper copies of the drilling notes are archived in the YNP Heritage Research Center.

Table 1. Borehole location, drilling dates, and depth of boreholes drilled in 2007 and 2008 in Yellowstone National Park, Wyoming.

\begin{tabular}{lccccc}
\hline \multicolumn{1}{c}{ Site name } & $\begin{array}{c}\text { Latitude } \\
\text { (decimal degrees) }\end{array}$ & $\begin{array}{c}\text { Longitude } \\
\text { (decimal degrees) }\end{array}$ & $\begin{array}{c}\text { Begin drilling } \\
\text { date }\end{array}$ & $\begin{array}{c}\text { End drilling } \\
\text { date }\end{array}$ & $\begin{array}{c}\text { Total depth } \\
\text { (feet) }\end{array}$ \\
\hline B205 Norris & 44.713520 & -110.678227 & July 8, 2008 & July 12, 2008 & 515 \\
B206 Canyon & 44.717700 & -110.511700 & June 14, 2008 & June 19, 2008 \\
B207 Madison & 44.618949 & -110.848568 & October 3, 2007 & October 13, 2007 & 600 \\
B208 Lake & 44.560110 & -110.401500 & October 15, 2007 & October 20, 2007 \\
Grant 1 (abandoned) & 44.395383 & -110.576130 & June 24, 2008 & June 25, 2008 \\
B944 Grant & 44.389669 & -110.543722 & July 16, 2008 & July 26, 2008 \\
B945 Panther Creek & 44.893963 & -110.744201 & August 5, 2008 & August 12, 2008 \\
\hline
\end{tabular}




\section{Lithologic Logging}

Drill cuttings were collected for lithologic description and laboratory analysis. This report presents field descriptions and initial laboratory analytical results as well as interpretations. Generally, representative cuttings were collected every $5 \mathrm{ft}$ of depth with a few exceptions related to problems during drilling.

Cuttings were collected from the drill rig discharge line and placed in either cloth sample bags or plastic bags. The amount and size of the cuttings varied with hardness of the rock and the drill bit. For example, welded tuffs drilled with a tricone bit generally yielded small amounts of fine cuttings. Conversely, large amounts of coarse cuttings (up to 1-2 centimeters $(\mathrm{cm}))$ resulted from drilling fractured rock. Sometimes, the drilling ejected small rocks $(7 \mathrm{~cm}$ by $5 \mathrm{~cm}$ by $5 \mathrm{~cm}$ ) from fractured, weathered, or autobrecciated zones.

\section{Field Observations}

A 10- to 20-power hand lens and occasionally a binocular microscope were used to identify and examine cuttings in the field. Use of a binocular microscope for rock identification occurred at the B207 Madison and B208 Lake boreholes and resulted in preliminary descriptions of stratigraphic units. Previous geologic mapping by the USGS (Richmond, 1973, 1974, 1977; Blank, Jr. and others, 1974; Christiansen, 1974, 1975; Christiansen and Blank, Jr., 1974, 1975; Richmond and Waldrop, 1975; Waldrop and Pierce, 1975; Christiansen, 2001; Christiansen and others, 2007) provided published lithologic descriptions, estimated thickness of some units, and described transitions between geologic units.

\section{Grain Mounts}

Grain mounts for selected, wet-sieved coarse cuttings (mesh 10, 35, and 60) were prepared by Applied Petrographics. These mounts were examined by using a 10-power binocular microscope and reflected light to further define lithologic units and to select samples for geochemical analysis. The grain mounts and field cuttings descriptions confirmed the geologic unit boundaries observed during drilling.

\section{Thin Sections}

For key zones, selected grain mounts (for example, fig. 3) were used for the production of polished thin sections, the description of cuttings, and the selection of samples for geochemical analysis. Thin sections of cuttings were examined with a Zeiss monocular petrographic microscope to identify quartz, feldspars, mafic minerals, and volcanic textures, as well as hydrothermal alteration. Examples of selected thinsection photomicrographs taken with a Leica digital microscope are shown in figures 3 and 4. In general, thin sections of rhyolite exhibited rounded quartz, sanidine, plagioclase, pyroxenes, perlitic texture, and flow banding (fig. 4) with aligned, needle-like, black microlites. In addition, the thin sections showed mineral overgrowths, zoned minerals, aggregates of minerals, sieved minerals, and minerals with re-entrants.

\section{Geochemical Analyses}

Rare earth element (REE) geochemical analysis of selected cuttings was used to confirm field-observed stratigraphy and to further describe the volcanic stratigraphy of the boreholes. To produce graphs with smoothed REE profiles, REE concentrations (appendix 1) were normalized by using chondrite values of Boynton (1985). These graphs were compared to REE profiles from analyses of reference samples collected from outcrops of Yellowstone volcanic units (table 2).

Table 2. Location of reference samples collected from Yellowstone volcanic units for rare earth element analysis, Yellowstone National Park, Wyoming.

\begin{tabular}{|c|c|c|c|c|}
\hline Volcanic unit & Sample ID & $\begin{array}{c}\text { Latitude } \\
\text { (decimal degrees) }\end{array}$ & $\begin{array}{c}\text { Longitude } \\
\text { (decimal degrees) }\end{array}$ & Comments \\
\hline Aster Creek flow & Aster Creek & 44.3600 & -110.5812 & Road cut; flow banded \\
\hline Dry Creek flow & Dry Creek & 44.4220 & -110.5867 & Road cut \\
\hline Gibbon River flow & Gibbon River Flow & 44.6637 & -110.7442 & Road cut; Gibbon Canyon, spherulitic \\
\hline Hayden Valley flow & Hayden Flow & 44.7052 & -110.5039 & Road cut; glassy \\
\hline Nez Perce Creek flow & Nez Perce & 44.6914 & -110.7467 & Outcrop; glassy \\
\hline Lava Creek Tuff-A & LCT G & 44.6642 & -110.7443 & Road cut; Gibbon Canyon; LCT G \\
\hline Lava Creek Tuff-B & LCT B O & 44.8169 & -110.7292 & Road cut; Obsidian Cliff; Federal Highways core; LCT B O \\
\hline Swan Lake Flat Basalt & PCV SS1 & 44.8977 & -110.7400 & Outcrop; PCV1 \\
\hline Swan Lake Flat Basalt & PCV BS4 & 44.8990 & -110.7393 & Outcrop; PCV3 \\
\hline Swan Lake Flat Basalt & PCV SC2 & 44.8922 & -110.7295 & Outcrop; Sheepeater Cliff; PCV SC2 \\
\hline Tuff of Bluff Point & Tuff of Bluff & 44.4515 & -110.5640 & Road cut \\
\hline West Thumb flow & WT Pumice & 44.4590 & -110.5174 & Cliff along lake shore; pumice \\
\hline West Thumb flow & WT Flow & 44.4588 & -110.5170 & Cliff along lake shore; glassy, brecciated flow \\
\hline
\end{tabular}



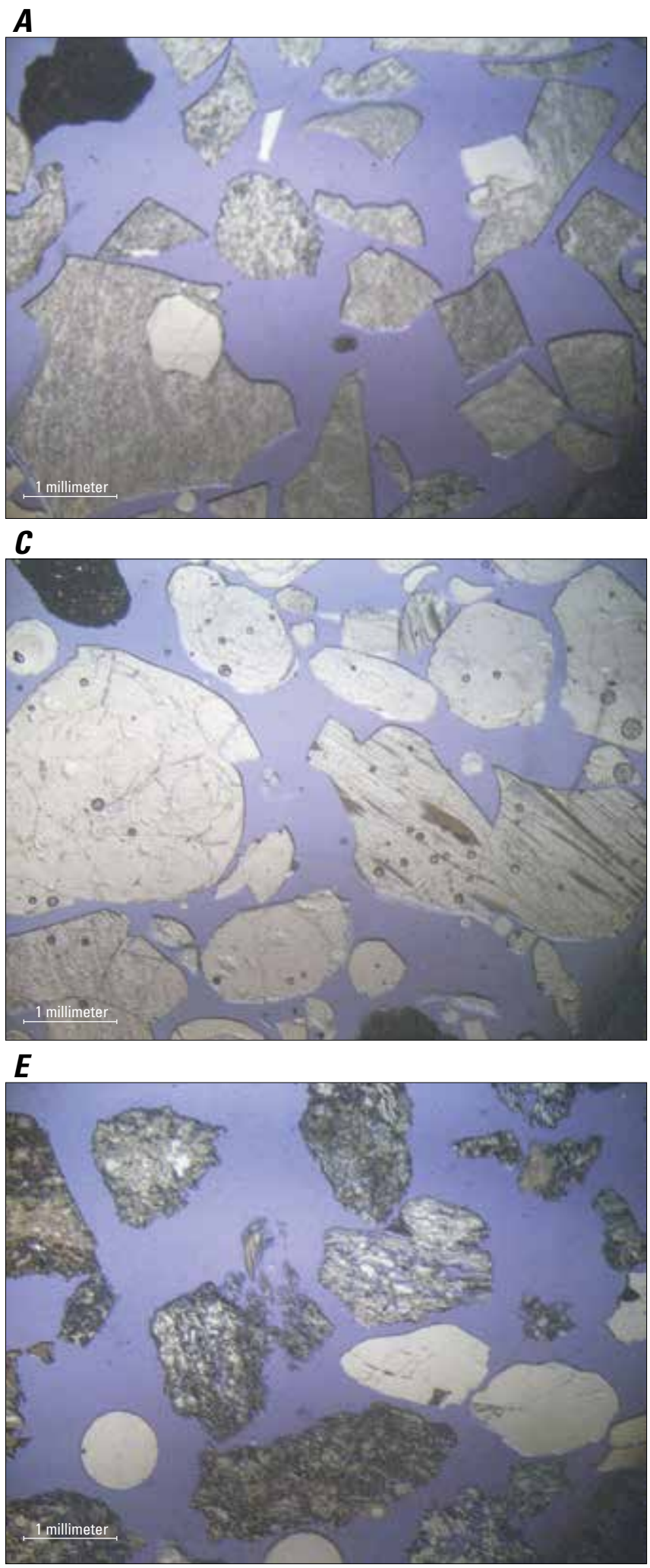
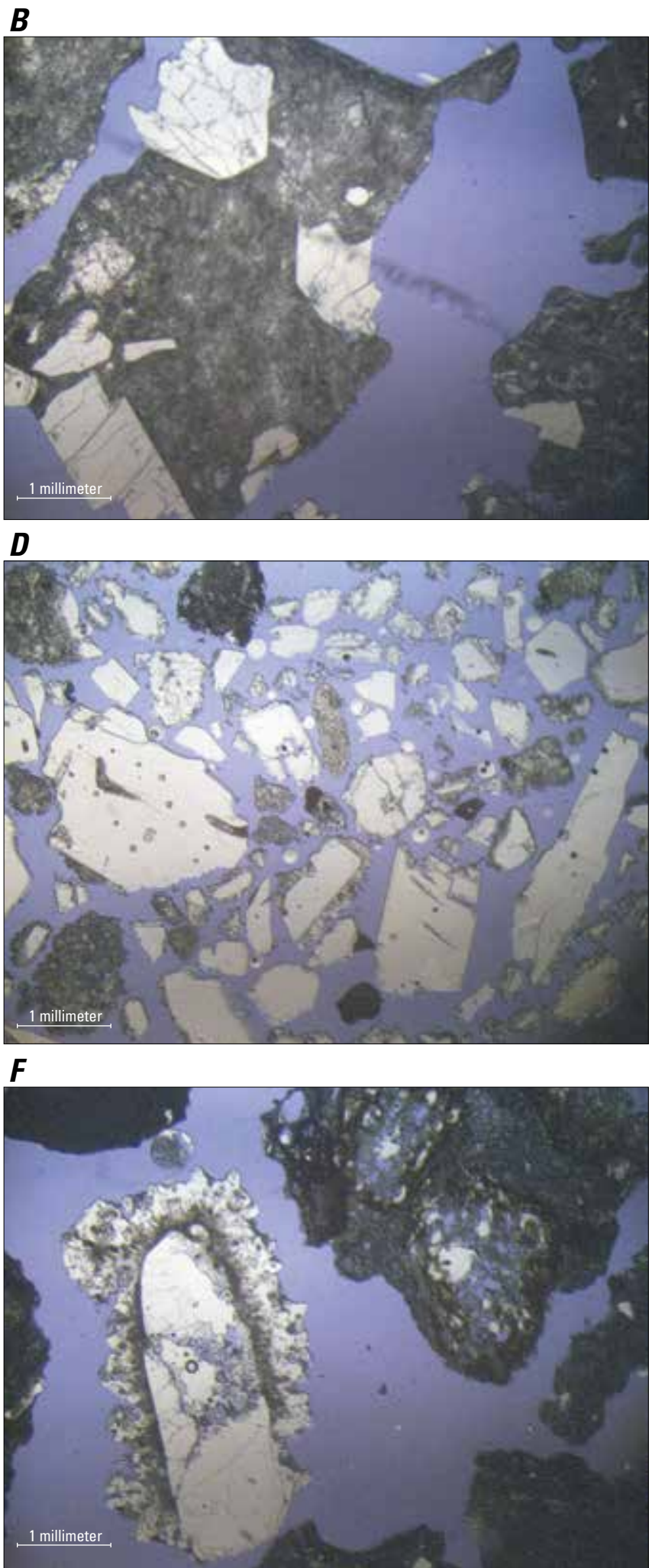

Light blue color represents epoxy and potassium feldspar stain

Figure 3. Photomicrographs of cuttings from $\boldsymbol{A}$, a glassy rhyolite flow showing quartz and feldspar phenocrysts at 30-foot depth in the B205 Norris borehole, $\boldsymbol{B}$, a welded tuff showing quartz and feldspar phenocrysts at 495-foot depth in the B205 Norris borehole, $\boldsymbol{C}$, a rhyolite showing perlitic texture and flow banding at 100-foot depth in the B206 Canyon borehole, $\boldsymbol{D}$, a tuffaceous sediment at 800-foot depth in the B208 Lake borehole, $\boldsymbol{E}$, a vitrophyric zone at 105-foot depth in the B944 Grant borehole, and $\boldsymbol{F}$, a sanidine phenocryst showing simple twinning within a chaotic zone at 260 -foot depth in the B944 borehole. 
A

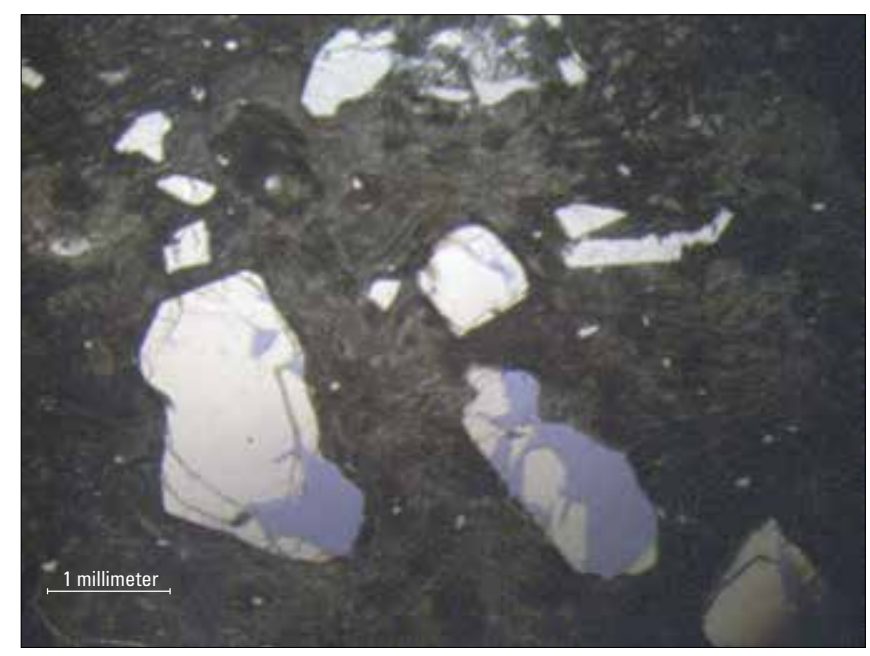

B

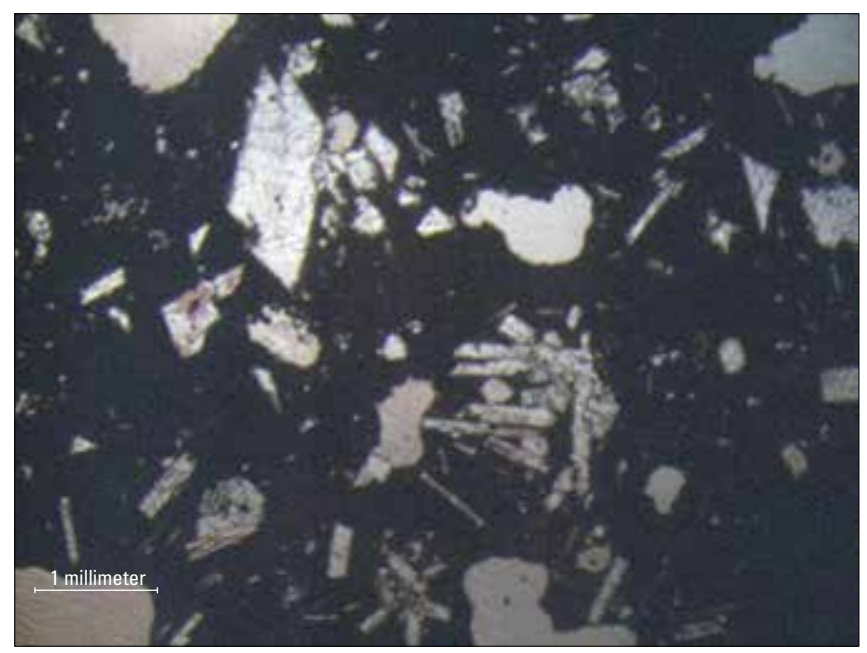

Notice the fiamme surrounding the phenocrysts in the B205 Norris borehole sample and the
cumulophyric texture shown in the B945 Panther Creek borehole sample. The irregular and non-euhedral shapes in the Panther Creek photomicrograph are voids within the scoria.

Figure 4. Photomicrographs of cuttings recovered during drilling of the $\boldsymbol{A}$, B205 Norris borehole at 300-foot depth, and $\boldsymbol{B}$, B945 Panther Creek borehole at 450-foot depth.

Washington State University GeoAnalytical Laboratory measured major- and trace-element concentrations in cuttings from the seven boreholes (appendix 1). Distinguishing between the various rhyolite flows, tuffs, and basalts required the analysis of major and trace elements. Because hydrothermal alteration affected some rock samples, an assessment of ignition loss (a measure of volatile element loss) at high temperature $\left(900^{\circ} \mathrm{C}\right)$ was necessary. Inductively coupled plasma-mass spectrometry (ICP-MS) was used to analyze samples for the following trace elements: scandium $(\mathrm{Sc})$, rubidium $(\mathrm{Rb})$, strontium $(\mathrm{Sr})$, yttrium $(\mathrm{Y})$, zirconium $(\mathrm{Zr})$, niobium $(\mathrm{Nb})$, cesium $(\mathrm{Cs})$, barium $(\mathrm{Ba})$, lanthanum $(\mathrm{La})$, cerium $(\mathrm{Ce})$, praseodymium $(\mathrm{Pr})$, neodymium $(\mathrm{Nd})$, samarium $(\mathrm{Sm})$, europium $(\mathrm{Eu})$, gadolinium $(\mathrm{Gd})$, terbium $(\mathrm{Tb})$, dysprosium (Dy), holmium (Ho), erbium (Er), thulium (Tm), ytterbium (Yb), lutetium (Lu), hafnium (Hf), tantalum (Ta), lead $(\mathrm{Pb})$, thorium $(\mathrm{Th})$, and uranium (U). The ICP-MS had detection limits at the parts per billion (ppb) level and typical precisions between 3 and 5 percent. X-ray fluorescence (XRF) was used to analyze the cuttings for the major elemental compounds silicon dioxide $\left(\mathrm{SiO}_{2}\right)$, titanium dioxide $\left(\mathrm{TiO}_{2}\right)$, aluminum oxide $\left(\mathrm{Al}_{2} \mathrm{O}_{3}\right)$, iron oxide $\left(\mathrm{FeO}_{2}\right)$, manganese oxide $(\mathrm{MnO})$, magnesium oxide $(\mathrm{MgO})$, calcium oxide $(\mathrm{CaO})$, sodium oxide $\left(\mathrm{Na}_{2} \mathrm{O}\right)$, potassium oxide $\left(\mathrm{K}_{2} \mathrm{O}\right)$, and phosphate $\left(\mathrm{P}_{2} \mathrm{O}_{5}\right)$, and the trace elements scandium $(\mathrm{Sc})$, vanadium $(\mathrm{V})$, chromium $(\mathrm{Cr})$, nickel $(\mathrm{Ni})$, copper $(\mathrm{Cu})$, zinc $(\mathrm{Zn})$, gallium (Ga), arsenic (As), Rb, Sr, Y, Zr, Nb, Cs, Ba, La, Ce, Nd, $\mathrm{Pb}, \mathrm{Th}$, and $\mathrm{U}$ with parts per million (ppm) detection limits. Although not as precise as the ICP-MS analyses at less than 200-300 ppm concentration, the XRF data have less uncertainty (less than 3 percent) at concentrations above that range; major elements analyzed by XRF typically have uncertainties less than 0.5 percent. Analytical methods are described in more detail in Johnson and others (1999), and online at http://environment.wsu.edu/facilities/geolab/technotes (accessed on March 19, 2014).

\section{Geophysical Logging}

After completion of the drilling at each site, geophysical parameters and temperature were measured in the boreholes. Incremental geophysical and temperature logs also were run during the drilling of the boreholes. Full depth logs run after completion of drilling are available from the PBO website at ftp://borehole.unavco.org/pub/borehole/ (accessed on March 9, 2014).

Geophysical logging was done with a Century Geophysical Corporation System VI logging system coupled with a Model VI 700M Drawworks and 700 meters of cable. The system consisted of four tools:

(1) 8074 Series Three Arm Caliper tool to measure the diameter of the boreholes.

(2) 8144 Series E Logging tool to record eight different properties: natural gamma, spontaneous potential, single-point resistance, 16-in. normal resistivity, 64-in. normal resistivity, 48-in. lateral resistivity, fluid resistivity, temperature, and change in temperature.

(3) 8344 Series Full Wave Sonic tool used a source and two receivers to record travel times, determine the density of the rock, and identify fractures. Measurements recorded were near and far travel times, borehole-compensated delta time, calculated sonic porosity, receiver gains, and near and far amplitudes. 
(4) 8804 Series Acoustic Televiewer "photographed" the borehole using sound waves and an internal magnetometer oriented the data. Using the picture and orientation information, the strike and dip of fractures and bedding planes can be calculated.

Commercially available software such as WellCad and a free reader can open the log files recorded in Century Geophysical format. The following websites provide access to the viewing software and logging data, respectively: (1) http://www.century-geo.com/cgc/Support/Downloads.aspx (accessed in April 2016), and (2) http://pboweb.unavco.org (accessed in April 2016). A precision logging tool measured borehole temperatures to assess thermal gradients in the holes and provide critical information for placing downhole instrumentation. Installation of downhole strainmeters and seismometers required borehole temperatures of less than $60^{\circ} \mathrm{C}$. A Fenwahle K212E thermistor probe based on a design by Sass and others (1971) and assembled by the University of Utah Thermal Research Group was used to measure temperatures. The probe and logging equipment attained a temperature precision of plus or minus ( \pm ) 2.5 millidegrees Celsius. Harris and Chapman (2007) described the complete specifications of the probe. Because temperature logs were run during the drilling of the boreholes and immediately following completion of the drilling, the measured temperatures may not be in equilibrium with the surrounding rocks.

\section{Water Sample Collection}

Water samples were collected and analyzed to document water-quality changes with depth and to provide data that could be assessed along with other lithologic and geophysical data to investigate groundwater and hydrothermal fluid flow in the near-surface volcanic rocks. Collecting water samples during the drilling of a well is less than ideal and involved a number of compromises to account for the expense of rig time, sediment, and drilling fluids.

The selection of depths from which water samples were collected was based on the water discharge rate from the drill rig and on changes in water-quality field parameters. Discharge from the drill rig was monitored during drilling. When changes in discharge were noted visually, drilling was stopped and discharge was estimated volumetrically with a 5-gallon bucket. Water temperature, $\mathrm{pH}$, and specific conductance were monitored in water discharged from the drill rig, and selected water samples were collected usually when discharge was greater than 10 gallons per minute $(\mathrm{gal} / \mathrm{min})$ or if there were significant changes in the field parameters. A few samples, however, were collected from zones that produced less than $10 \mathrm{gal} / \mathrm{min}$.

Water samples were collected at the discharge line from the drill rig. Prior to collecting a sample, water was purged from the borehole by air lifting for approximately 10 minutes. During purging, the clarity (turbidity) of the water was observed visually. Specific conductance and temperature were measured at approximately 2-minute intervals and recorded. Ideally, after 10 minutes, the purged water was less turbid and specific conductance and temperature had stabilized. If conductance and temperature did not stabilize within 10 minutes, purging continued. Once conductance and temperature had stabilized, a sample was collected; however, a sample was still collected if field parameters had not stabilized after 20 minutes.

Samples were collected in a new 1-gallon plastic bottle. The bottle was partially filled with water from the discharge line and rinsed twice before filling. Sediment in the bottle was allowed to settle before filtering with a 0.45 -micron cartridge filter, and sample bottles were either filled in the field or later in the laboratory. Allowing the sediment to settle and delaying filling sample bottles were necessary because of the abundant fine sediment and potential for clogging filters. Additional dissolution of some constituents under these conditions is possible and may have affected the final analytical results. Unfiltered sample bottles were filled by pumping water from the 1-gallon bottle with a peristaltic pump. Cation and trace-metal samples were filtered and acidified with ultrapure concentrated nitric acid, anion samples were filtered and not acidified, and samples for iron ( $\mathrm{Fe}$ ) and arsenic (As) redox speciation were filtered and acidified with 6 molar re-distilled hydrochloric acid.

Water temperature, $\mathrm{pH}$, and specific conductance were measured when each sample was collected. Specific conductance and $\mathrm{pH}$ meters were calibrated using standards and buffers that bracketed the sample values.

\section{Water Sample Analyses}

For dissolved and total recoverable samples, major cations were determined by inductively coupled plasma-atomic emission spectrometry (ICP-AES) using a Leeman Labs spectrometer. Trace-metal concentrations were determined by inductively coupled plasma-mass spectrometry (ICP-MS) using a Perkin Elmer Sciex Elan 6000 spectrometer and using a method similar to that described in Garbarino and Taylor (1979). Iron redox species were determined by using a modification of the FerroZine colorimetric method (Stookey, 1970) with a Hewlett Packard 8453 diode array UV/VIS spectrophotometer. Arsenic redox species were determined by using a Perkin Elmer hydride generation atomic absorption spectrometer system (Analyst 300 and FIAS 100), and using a method similar to that of McCleskey and others (2005). Concentrations of major anions were determined by ion chromatography (IC) using a Dionex 600 ion chromatograph (Brinton and others, 1995). Alkalinity (as bicarbonate) was determined by using an Orion 960 autotitrator and standardized sulfuric acid titrant (Barringer and Johnsson, 1996).

Double-distilled de-ionized water and re-distilled acids using a sub-boiling purification technique were used in all standard preparations. For ICP-MS and ICP-AES, external standards, blanks, sample dilutions, and spiking solutions were made with commercial trace analysis grade elemental standards. For IC determinations, standards were prepared from compounds of the highest commercially available purity. Many of the quality assurance-quality control methods described by McCleskey and others (2004), including use of 
USGS standard reference water samples (SRWS) as independent quality control standards, calculation of charge balance, and analyses of the samples by multiple methods (for example, ICP-AES and ICP-MS) were utilized.

For stable-isotope analysis, samples were collected in glass containers with polyseal caps, leaving no head space, and analyzed by the USGS Stable Isotope Laboratory in Reston, Virginia using methods described in Révész and Coplen (2008a, b). Tritium samples were collected in 1-liter polyethylene bottles with polyseal caps, and analyzed by the University of Utah Dissolved and Noble Gas Laboratory using the helium ingrowth method (Bayer and others, 1989).

\section{Results}

The physical and geochemical data from each of the boreholes are presented in the following sections. Information includes a brief description of the access to each site, a summary of the general geology and stratigraphy, geochemical analyses of the cuttings, a summary of drilling notes and water chemistry data, as well as internet references for detailed drilling notes, and temperature and geophysical logging data. Geochemical analyses of cuttings collected from the boreholes and for reference samples from Yellowstone volcanic units are compiled in appendix 1. Appendix 2 presents the water chemistry data for samples collected at selected depths during drilling of the boreholes. Strainmeter and seismometer installation information and data, as well as drilling notes and geophysical logging data for each of the boreholes are available at http://pbo.unavco.org/data/bsm/ (accessed on March 9, 2014).

\section{B205 Norris Borehole}

\section{Location}

The B205 Norris borehole is located to the south and east of Norris Junction (fig. 5). Access to the borehole is provided by a National Park Service (NPS) service road (closed to public travel) that provides access to the Norris sewage treatment plant and to telecommunications facilities.

\section{General Geology}

The B205 Norris borehole and the nearby Norris Geyser Basin occur outside the 639,000-year old Yellowstone caldera (fig. 5). Rhyolitic domes, such as the Geyser Hill dome and the Geyser Creek dome, also occur outside the caldera. Hydrothermal activity around the rhyolitic domes may be expressed as a hydrothermal basin with considerable spatial extent or as small hydrothermal seeps. Numerous faults and fractures provide permeable pathways for heat and fluids to hydrothermally alter bedrock and various Quaternary-age sediments.

On the basis of previous mapping and nearby outcrops, the B205 Norris borehole was expected to penetrate a rhyolite flow and a tuff (Fenner, 1936; Christiansen, 1975; White and others, 1975). A glassy rhyolite flow with fractures at the surface was mapped by Christiansen (1975) as the Gibbon River flow (fig. 5). Beneath the 118,000 $\pm 10,000$-year old Gibbon River flow (Abedini and others, 2007), lies the 110,000 $\pm 3,000$-year old Solfatara flow (Christiansen, 1975, 2001), and the 639,000 $\pm 2,000$-year old Lava Creek Tuff (LCT) members B (LCT-B) and A (LCT-A) (Lanphere and others, 2002), based on outcrops and the stratigraphy of nearby C-2, Y-9, and Y-12 boreholes in Norris Geyser Basin (fig. 5). In the C-2 borehole, $78 \mathrm{ft}$ of LCT-B were identified. In the nearby Y-9 and Y-12 boreholes, as much as $128 \mathrm{ft}$ of LCT-B were encountered (Christiansen, 1975). Approximately 1 mile (mi) east of the B205 Norris borehole, Christiansen (1975) described LCT-A as having a similar lithology to LCT-B, but noted that LCT-B generally weathers gray, brown, or pinkish-gray whereas LCT-A generally weathers brown and forms rounded outcrops beneath LCT-B at Virginia Cascades.

\section{Stratigraphy}

A preliminary interpretation of the B205 Norris borehole identified rhyolite flow(s) from 0-205 ft and ash-flow tuff from $205-515 \mathrm{ft}$ (table 3 ). The borehole penetrated pink to glassy black rhyolite flow(s) from near-surface to approximately $205 \mathrm{ft}$. Between 205 and $250 \mathrm{ft}$, the rock and associated cuttings changed, and widening of the borehole occurred, as indicated by caliper measurements; this interval is characterized primarily by tuff. From $250-255 \mathrm{ft}$, free bipyramidal quartz was observed in the cuttings. A caliper log indicated fractured rock from 265-280 ft. From 290-305 ft, a "soft" zone was encountered with mud and broken gray rocks. Paleorange mud, laminated gray-green mud, pale-brown, rounded and aerodynamically shaped glass fragments, and pale graygreen discharge water characterized this zone. The drill rig produced fragments of pink-gray to red-brown welded tuff below this soft zone to the bottom of the hole $(515 \mathrm{ft})$. Based on visual observations of LCT outcrops approximately $1 \mathrm{mi}$ east of the B205 Norris borehole, the estimated thickness of LCT-B, and the soft zone at a depth of about $300 \mathrm{ft}$, it is possible that the B205 Norris borehole penetrated the transition between LCT-B and the underlying LCT-A. In general, water flow occurred at major boundaries between lithologies and fractured zones within the LCT (table 3).

\section{Geochemical Analysis of Cuttings}

The normalized REE profiles indicate that at least three rhyolitic units were penetrated by the B205 Norris borehole. From the glassy surficial outcrops to approximately $135 \mathrm{ft}$, the REE profiles are similar to the reference sample from the Gibbon River flow (fig. 6). The change in REE geochemistry at 190-195 ft may reflect the basal portion of the Gibbon River flow. The Gibbon River flow reference sample was collected in Gibbon Canyon west of the borehole (table 2). From $250 \mathrm{ft}$ to the bottom of the borehole, the REE geochemistry is consistent with the LCT (fig. 7). The decrease in cerium 


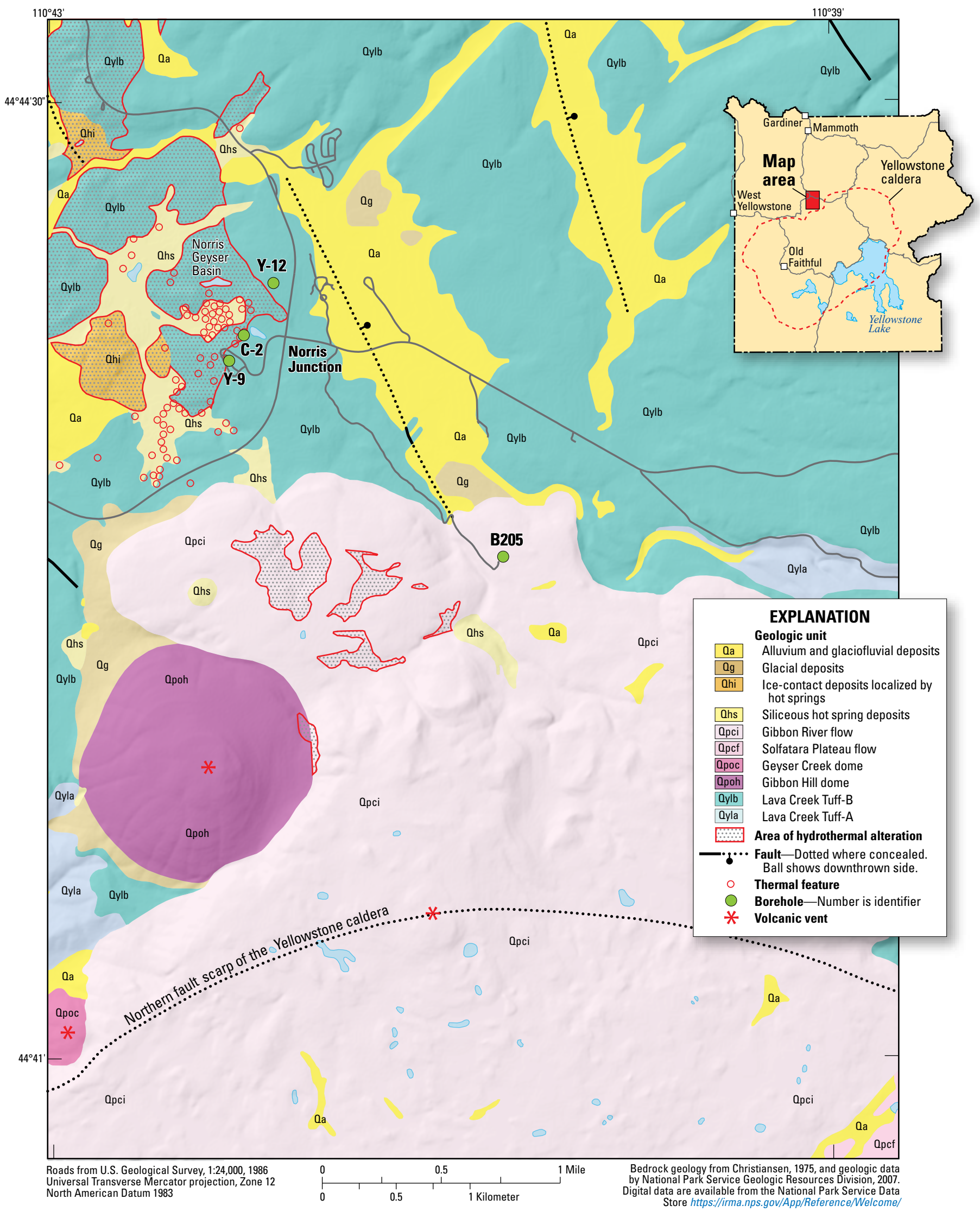

Figure 5. Bedrock geology in the vicinity of the B205 Norris borehole, Yellowstone National Park, Wyoming. 
Table 3. General stratigraphy and lithology for the B205 Norris borehole, Yellowstone National Park, Wyoming.

\begin{tabular}{|c|c|c|}
\hline Depth (feet) & Description & Comments \\
\hline $0-90$ & Rhyolite & Glassy at surface \\
\hline $90-205$ & Rhyolite & Altered at $185-190$ feet; glassy at 200 feet \\
\hline $290-310$ & Pale-orange to gray mud with gray rocks & Green-gray laminated muds \\
\hline $465-470$ & Red-brown tuff & Transition zone, rock harder to drill \\
\hline $470-515$ & Red-brown tuff & Red-brown tuff \\
\hline
\end{tabular}

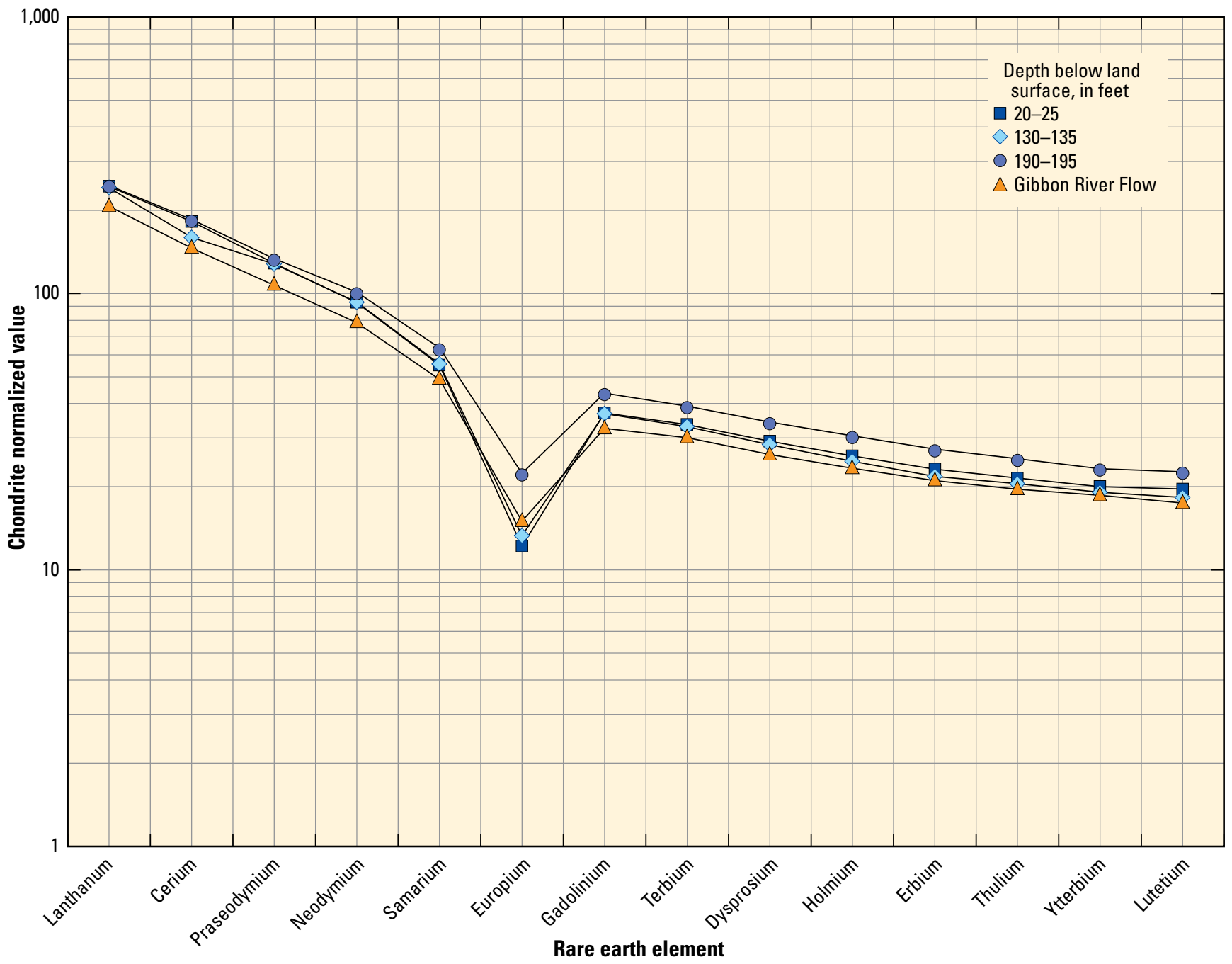

Figure 6. Rare earth element chemistry using chondrite normalized values of Boynton (1985) for selected depths in the upper part of the B205 Norris borehole, and for a reference sample from the Gibbon River flow (Gibbon River Flow), Yellowstone National Park, Wyoming. 


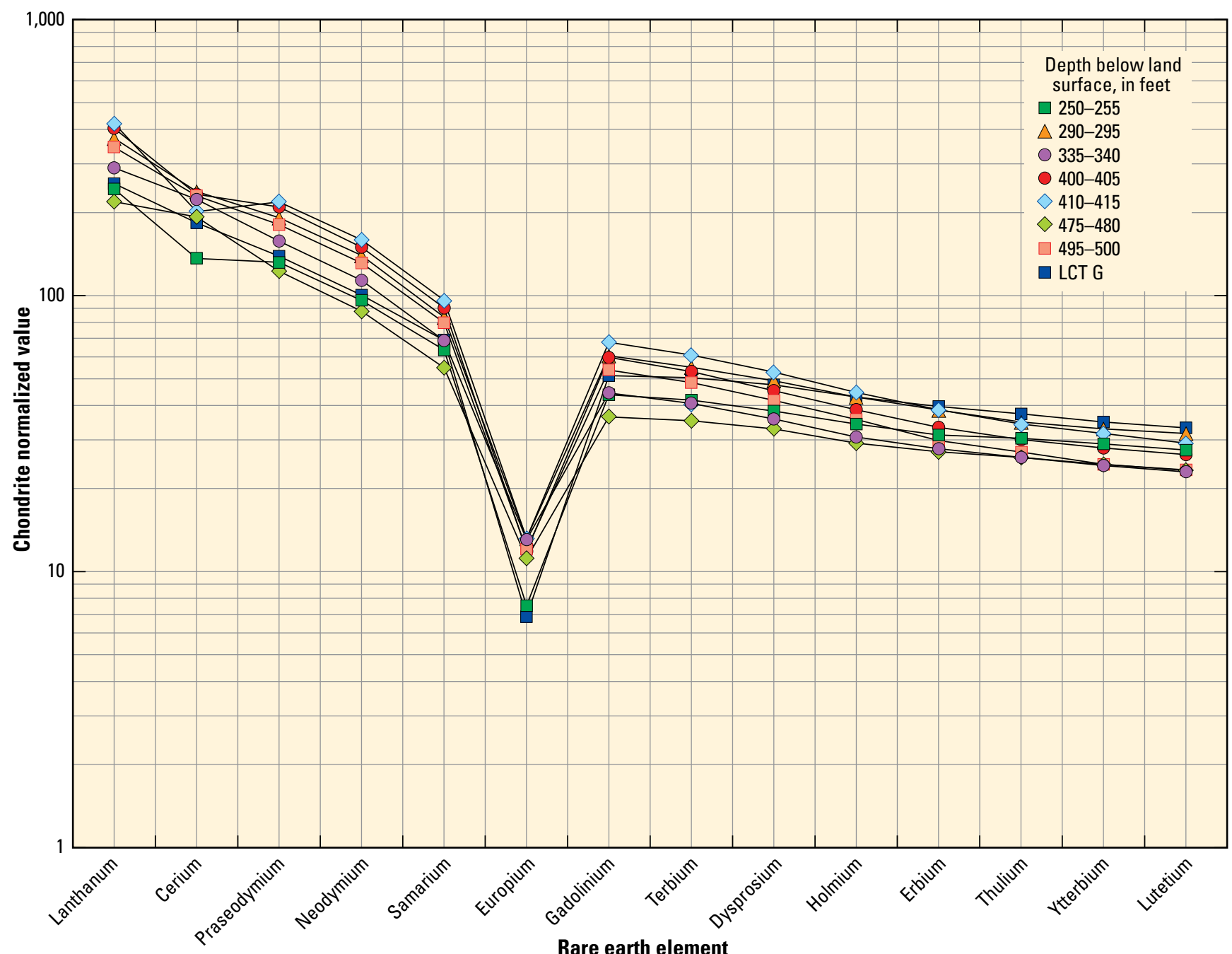

Figure 7. Rare earth element chemistry using chondrite normalized values of Boynton (1985) for selected depths in the lower part of the B205 Norris borehole and for a reference sample from the Lava Creek Tuff (LCT G), Yellowstone National Park, Wyoming.

concentration at depths of 250 and $410 \mathrm{ft}$ may reflect redox reactions and significant hydrothermal alteration at these depths (Piper and Bau, 2013). The decrease in cerium is consistent with the red, orange, and yellow hydrothermal alteration colors on cuttings and the gray-green or yellow water produced during drilling. Marfil and Maiza (2012) noted that variances in the concentration of cerium and other elements in altered rocks "probably are due to hydrothermal processes." The REE curves for the lower part of the B205 Norris borehole also may reflect problems with drilling through the interval between 210 and $250 \mathrm{ft}$. For comparison, figure 7 also shows REE geochemistry from an LCT-A outcrop sample (LCT G) collected in Gibbon Canyon (table 2).

Concentrations of zirconium and niobium may be used to identify the LCT within the B205 Norris borehole (fig. 8). Von Stauffenberg (2015) identified compositional trends that permit discrimination between LCT-A and LCT-B, as well as their subunits. For lower LCT-B, Von Stauffenberg (2015) identified a zirconium concentration between 170 and $190 \mathrm{ppm}$ and a niobium concentration between 67 and 74 ppm. For upper LCT-A, Von Stauffenberg (2015) identified a zirconium concentration between 185 and 300 ppm and a niobium concentration between 49 and $51 \mathrm{ppm}$. The results of geochemical analysis of rock from the 250-255-ft interval plot close to lower LCT-B values (fig. 8, LCT VC; Von Stauffenberg, 2015) at Virginia Cascades. Reference samples LCT-B O and LCT G from this study (table 2) also plot near Von Stauffenberg's (2015) LCT-B samples at Virginia Cascades. Published LCT-A geochemistry data (LCT-A Upper BV, Bindeman and Valley, 2001; LCT-A Upper RC, Christiansen, 2001; and LCT-A Upper JS, Von Stauffenberg, 2015) show that samples from the lower part (435-500-ft depth) of the B205 Norris borehole (fig. 8) generally plot between the Upper BV LCT-A at Tuff Cliffs and the Upper RC LCT-A vitrophyre on Mount Jackson (fig. 8). The B205 Norris borehole samples from 290-415 ft plot between the Upper RC LCT-A vitrophyre on Mount Jackson and the LCT-A Upper JS locality at Purple Mountain summit (fig. 8; Von Stauffenberg, 2015). However, the borehole 


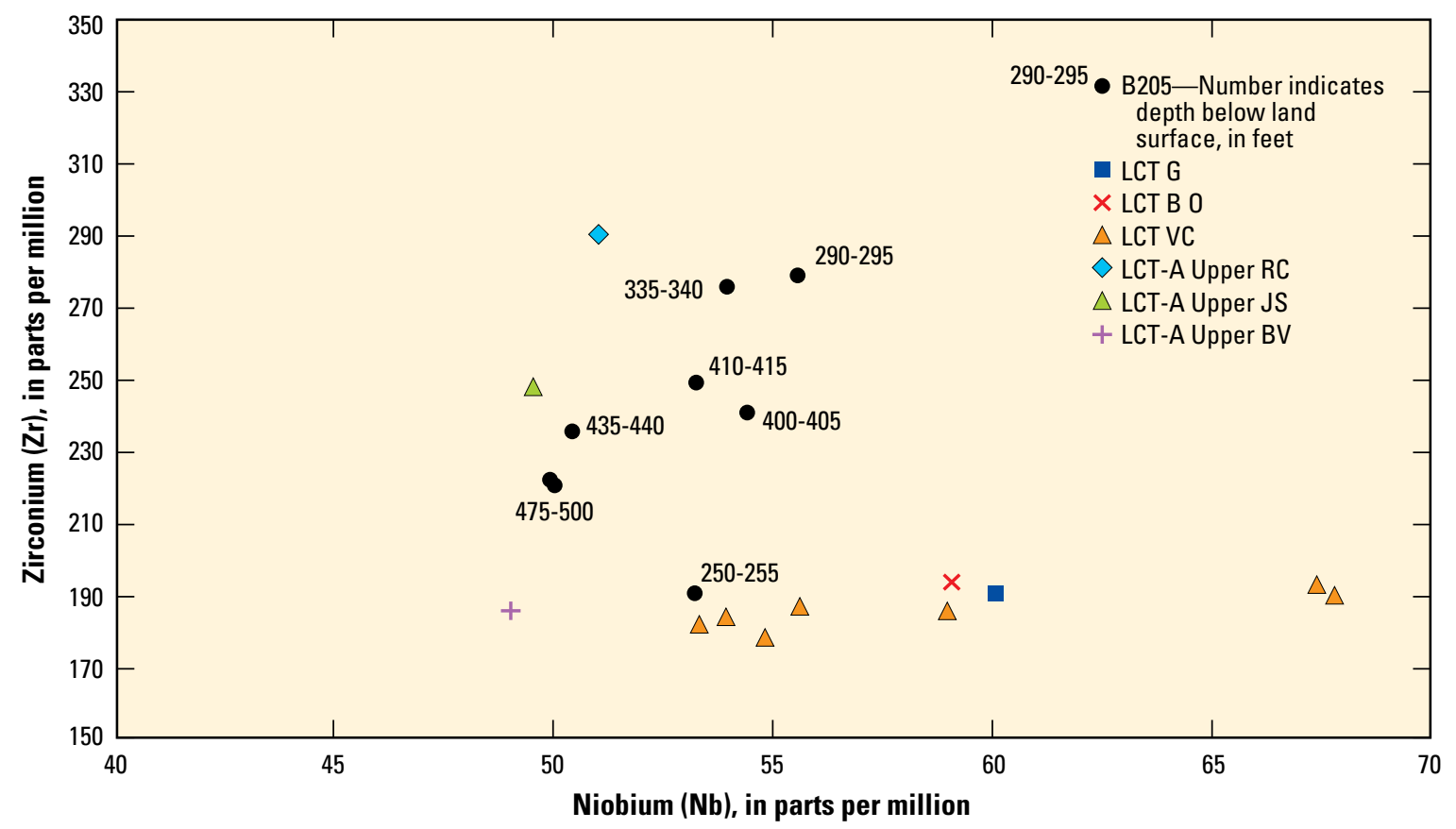

Figure 8. Concentrations of zirconium (Zr) versus niobium (Nb) for B205 Norris borehole samples, reference samples of the Lava Creek Tuff (LCT) from this study (LCT B 0 and LCT G), a sample (LCT-A Upper BV) from Bindeman and Valley (2001, sample LCT3-A), a sample (LCT-A Upper RC) from Christiansen (2001, sample 79Y-194A), and for samples from Von Stauffenberg (2015, LCT VC and LCT-A Upper JS).

samples do not fall within the range of zirconium and niobium concentrations identified by Von Stauffenberg (2015) for the upper LCT-A. Additional study may identify a reason for the shift in niobium concentrations between 290 and $405 \mathrm{ft}$. Thus, the geochemistry data indicate that the B205 Norris borehole probably penetrated the lower LCT-B and upper LCT-A.

\section{Water Chemistry}

Water samples were collected from 35, 105, 245, 445, and $515 \mathrm{ft}$ below land surface during drilling of the B205 Norris borehole. The water sample at $35 \mathrm{ft}$ was collected when water was first encountered in the borehole. The water discharge rate from the drill rig was less than $0.5 \mathrm{gal} / \mathrm{min}$, and the volume of water collected was insufficient to measure field parameters or for a tritium sample. Some of the results of analysis of the water sample collected at $35 \mathrm{ft}$ were unusual and are difficult to interpret. The stable-isotope values $\left(\delta \mathrm{D}\right.$ and $\left.\delta^{18} \mathrm{O}\right)$ are isotopically much heavier than the values from other depths in the borehole $(-116.27 \%$ vs -140.73 to $-144.19 \%$, and $-14.6 \%$ vs -18.83 to $-19.08 \%$ ). Concentrations of calcium and sulfate were also much greater than in other samples from the borehole (appendix 2).

There are large temperature and water chemistry gradients with depth in the B205 Norris borehole. Water temperature was $14.1^{\circ} \mathrm{C}$ at $105 \mathrm{ft}$ and increased to $66.9^{\circ} \mathrm{C}$ at $515 \mathrm{ft}$ (appendix 2). Likewise, specific conductance increased from 58 microsiemens per centimeter $(\mu \mathrm{S} / \mathrm{cm})$ at $25^{\circ} \mathrm{C}$ at $105 \mathrm{ft}$ to $1,050 \mu \mathrm{S} / \mathrm{cm}$ at $515 \mathrm{ft}$. Some of the anion, cation, and trace-element concentrations also change with depth (appendix 2). Stable-isotope values are generally within the range of precipitation values and cold water samples reported for the Yellowstone region ( $\delta \mathrm{D},-115$ to $-153 \%$ and $\delta^{18} \mathrm{O},-15.2$ to $-20.2 \%$ ) (Kharaka and others, 2002). Tritium concentrations decreased with depth from 8.8 to 2.0 tritium units (TU).

\section{Drilling Notes}

Drilling notes and geophysical logs for the B205 Norris borehole can be found at ftp://borehole.unavco.org/pub/borehole/B205. Drilling began on July 8, 2008, and ceased on July 12,2008 , at a depth of $515 \mathrm{ft}$ with a measured bottom hole temperature of $66.9^{\circ} \mathrm{C}$. Major water production zones are shown in table 4 . The driller noted one lost circulation zone at 95 to $97 \mathrm{ft}$. Zones of varying hardness as determined by drill bit penetration, were noted throughout the hole.

Table 4. Major water production zones and temperature in the B205 Norris borehole, Yellowstone National Park, Wyoming.

\begin{tabular}{ccccc}
\hline Date & $\begin{array}{c}\text { Time } \\
\text { (Mountain } \\
\text { Daylight Time) }\end{array}$ & $\begin{array}{c}\text { Depth } \\
\text { (feet) }\end{array}$ & $\begin{array}{c}\text { Discharge } \\
\text { (gallons per } \\
\text { minute) }\end{array}$ & $\begin{array}{c}\text { Temperature } \\
\text { (degrees } \\
\text { Celsius) }\end{array}$ \\
\hline July 8, 2008 & $15: 58$ & 105 & 60 & 14.1 \\
\hline July 9, 2008 & $10: 30$ & 245 & 75 & 22.6 \\
\hline July 9, 2008 & $12: 36$ & 390 & 80 & 25.3 \\
\hline July 9, 2008 & $15: 08$ & 445 & $110-120$ & 24.2 \\
\hline
\end{tabular}




\section{B206 Canyon Borehole}

\section{Location}

The B206 Canyon borehole is located southwest of Canyon Village (fig. 9). An NPS service road that intersects the Grand Loop Road near the B206 borehole provides non-public access to the site. The borehole is located in a small meadow about $0.35 \mathrm{mi}$ west of the Grand Loop Road.

\section{General Geology}

The Canyon Village area and the B206 Canyon borehole occur within the Yellowstone caldera (fig. 9). There is a complex geologic history associated with the formation of the Yellowstone caldera, the course of the Yellowstone River, and Quaternary glaciation. In places, faults and fractures provide permeable pathways for heat and fluids to hydrothermally alter bedrock and various Quaternary sediments. The hydrothermal activity may be visible at the surface or underlie a grassy meadow.

Various rhyolite flows and tuffs as well as glacial sediments are mapped in the general area around Canyon Village. The surficial geology at the B206 Canyon borehole is mapped as brown-gray, ice-dammed lake silts that weather bluegray and vary from 20-200 ft in thickness (Richmond and Waldrop, 1975). This layer of sediments locally overlies the 102,000 $\pm 4,000$-year old Hayden Valley flow. Not far from the B206 Canyon borehole, the Hayden Valley flow occurs along the Yellowstone River (Christiansen, 1975; Christiansen and others, 2007). Along the Yellowstone River and road, outcrops provide evidence that the Hayden Valley flow also covered sediments that were incorporated into the base of the lava flow (R.L. Christiansen, U.S. Geological Survey, oral comm., 2015). Between the Hayden Valley flow and the Canyon flow, Christiansen (1975) mapped a unit known as "sediments of the Upper Falls." Near the B206 Canyon borehole, the Solfatara flow (Christiansen, 2001) overlies the 56-ft thick Hayden Valley flow and its steep flow front forms a tree-covered hillside to the west of the B206 Canyon borehole. Rhyolite flows and tuffs older than the approximately 100,000-year old lava flows mapped in the 15-minute Canyon quadrangle include the following: the 479,000 10,000 -year old Tuff of Sulfur Creek, the 484,000 $\pm 10,000$-year old Canyon flow, and the 486,000 $\pm 42,000$-year old Dunraven Road flow (Christiansen, 2001).

\section{Stratigraphy}

A preliminary stratigraphic interpretation of data from the B206 Canyon borehole is described in table 5. Approximately 35-40 ft of clay and sediment overlie a glassy rhyolite flow. From 40-145 ft, the borehole penetrated $105 \mathrm{ft}$ of glassy rhyolite, with an apparent discontinuity at the base of the interval. The loss of circulation at $145 \mathrm{ft}$, muddy water from the discharge line, and mud balls from 195-200 ft indicated fine-grained sediment and rock. The drillers also noted that the zone from 175-295 ft seemed to be "weathered and broken." These physical observations during drilling indicate a significant change in the rock sequence between the glassy upper rhyolite and the lower rhyolite flows. The cuttings from $200-400 \mathrm{ft}$ consisted of dark-gray rhyolite.

\section{Geochemical Analysis of Cuttings}

The REE geochemical analyses of cuttings from the B206 Canyon borehole indicate that two rhyolites were likely encountered: the Hayden Valley flow and the Canyon flow (fig. 10). The REE analysis of the glassy cuttings from $100-105 \mathrm{ft}$ is most similar to the REE geochemistry of the Hayden Valley flow (table 2). The REE geochemistry at $165-170 \mathrm{ft}$ is similar to the published REE geochemistry (Pritchard, 2011; Pritchard and Larson, 2012; reference samples 08CP24-weathered glass and 08CP55) of the Canyon flow. The REE geochemistry at 165-170 ft may reflect a transition zone between the Hayden Valley and Canyon flows as noted during drilling. The REE geochemistry at $400 \mathrm{ft}$ probably reflects the geochemistry of the hydrothermally altered Canyon flow. Physical observations during drilling, previously mapped geology, and examination of outcrops also indicate that the B206 Canyon borehole likely penetrated the Hayden Valley and Canyon flows. Additional reference samples from the Canyon flow may provide a better geochemical correlation with the basal rhyolite in the B206 Canyon borehole.

\section{Water Chemistry}

Two water samples were collected during drilling of the B206 Canyon borehole under less than ideal conditions. The samples were collected from depths of 306 and $342 \mathrm{ft}$ below land surface (appendix 2). The samples were collected with a 3 -ft long bailer because the borehole was not producing enough water to airlift for sampling although there was measureable water in the bottom of the hole. Bailed water

Table 5. General stratigraphy and lithology for the B206 Canyon borehole, Yellowstone National Park, Wyoming.

\begin{tabular}{cll}
\hline Depth (feet) & \multicolumn{1}{c}{ Description } & \multicolumn{1}{c}{ Comments } \\
\hline $2-30$ & Clay & Generally brown and hard; some gray and gray-green clay with rock fragments \\
$30-35$ & Glassy sediments & Light-gray cuttings \\
\hline $35-145$ & Rhyolite & Glassy rock at 40-65 feet; hole cased above 145 feet; lost circulation at 145 feet \\
$145-200$ & Sediments/rhyolite & Opaque brown to red-brown water from 145-165 feet; mud balls from discharge pipe at 195-200 feet \\
\hline $200-400$ & Dark-gray rhyolite & Sugary from 235-250 feet, 305-310 feet, and 335-340 feet; altered colors at base of hole \\
\hline
\end{tabular}




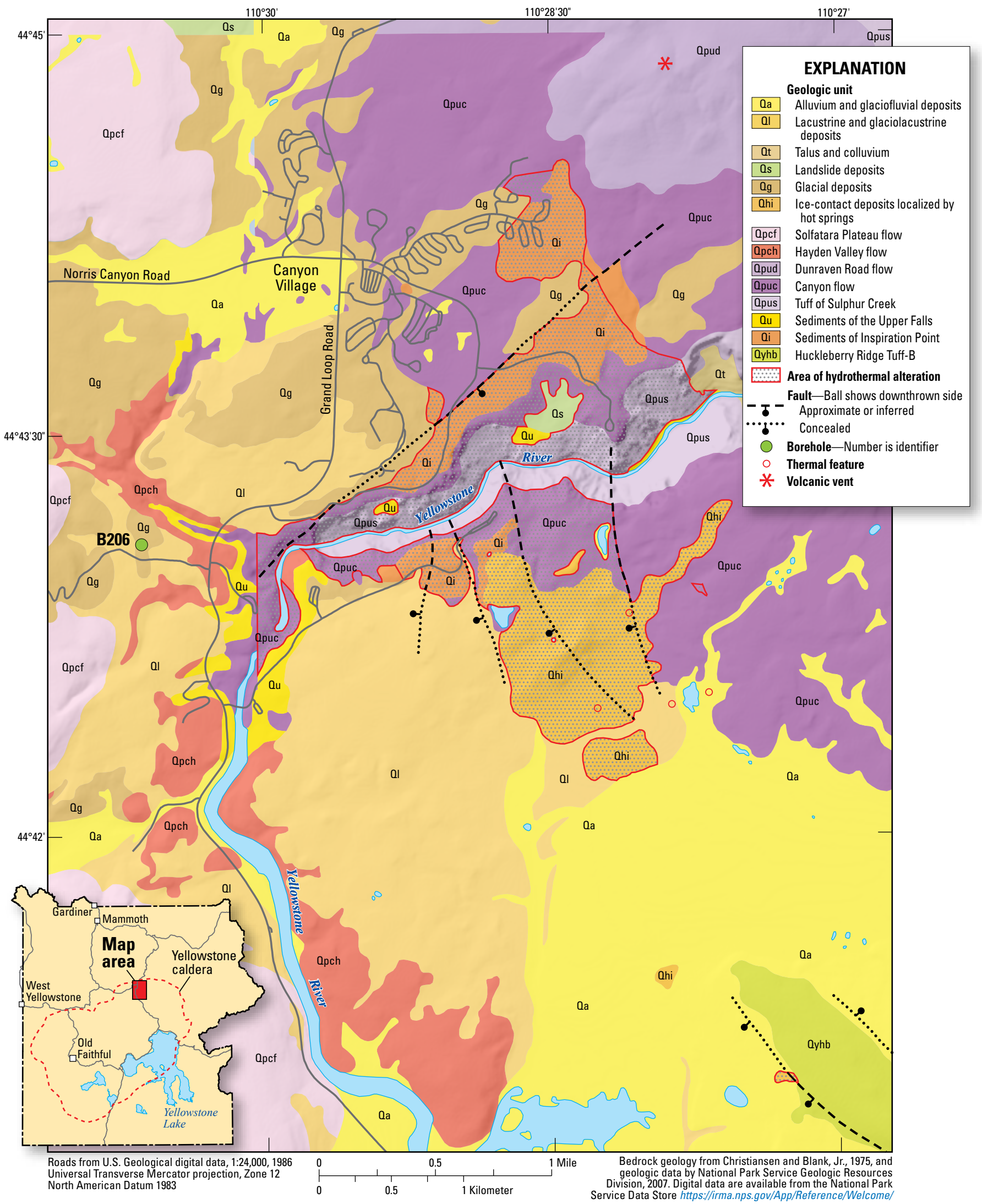

Figure 9. Bedrock geology in the vicinity of the B206 Canyon borehole, Yellowstone National Park, Wyoming. 


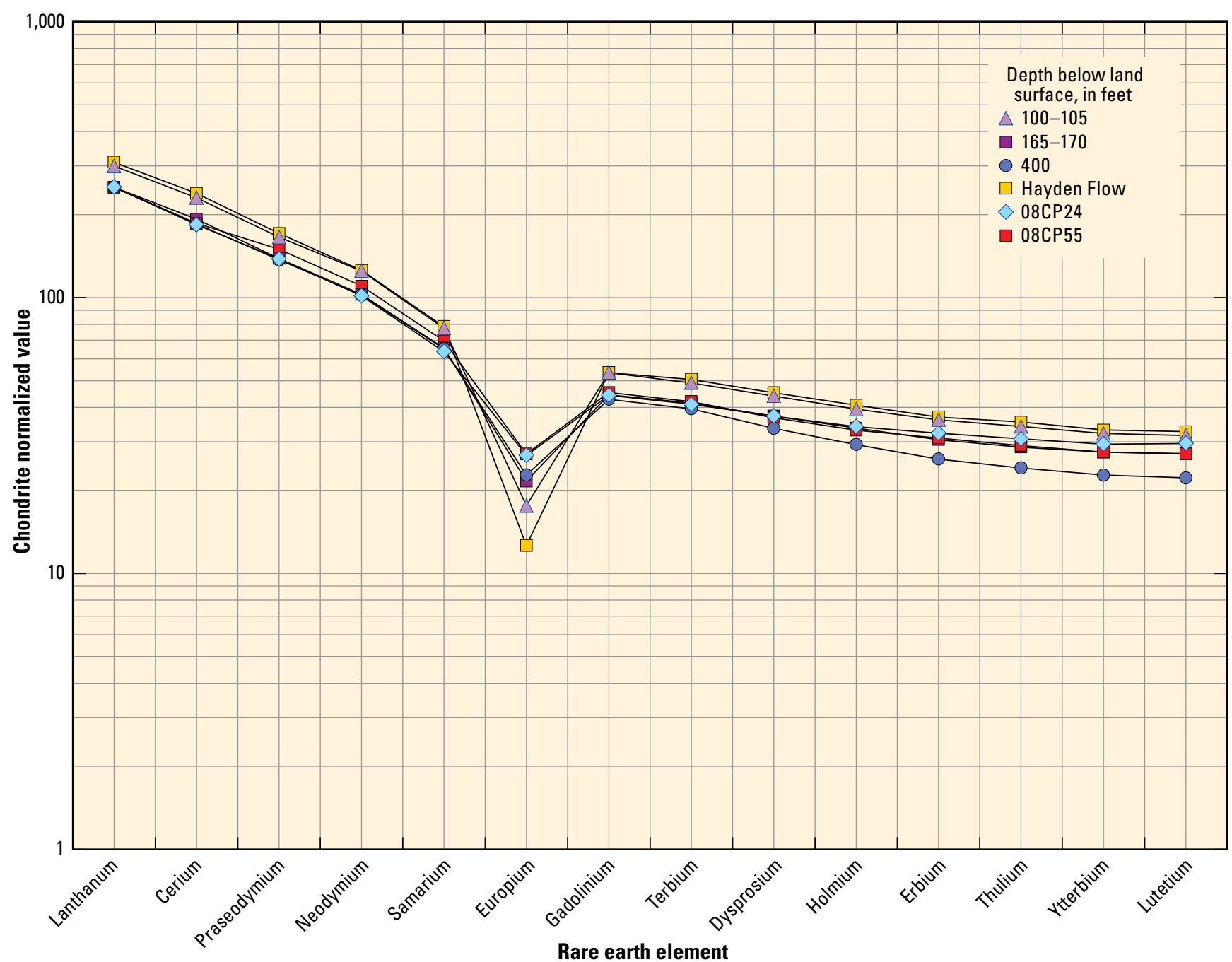

Figure 10. Rare earth element chemistry using chondrite normalized values of Boynton (1985) for selected depths in the B206 Canyon borehole and for reference samples from the Hayden Valley flow (Hayden Flow) and the Canyon flow (08CP24 and 08CP55), Yellowstone National Park, Wyoming.

was composited in a 1-gallon jug and processed according to protocols described in the "Methods" section.

The first sample collected at a depth of $306 \mathrm{ft}$ probably does not represent water from the aquifer. The drillers added water pumped and transported from the Yellowstone River to the upper part of the borehole to help lift cuttings to the surface. Some of this water may have still been in the hole when the sample was collected. Stable-isotope and tritium data (appendix 2) indicate that the water sampled likely originated from the Yellowstone River. The stable-isotope ratio is heavier (less negative) than that in any of the other samples with the exception of a water sample from Yellowstone Lake, and the water has an evaporative signature. In addition, the tritium concentration is similar to current precipitation and also similar to water from Yellowstone Lake. The major- and trace-element concentrations in the water sample collected at a depth of $345 \mathrm{ft}$ are significantly different than the concentrations in the sample collected at $306 \mathrm{ft}$ (appendix 2), probably indicating that this is native water from the aquifer. Concentrations of major ions and trace elements are similar to concentrations in samples collected from the other boreholes with water temperatures greater than $40{ }^{\circ} \mathrm{C}$ (appendix 2). Both of the samples, however, were collected under less than ideal conditions and analytical results should be used with caution. Because there was insufficient water in the borehole to purge by airlifting and only small volumes of water were bailed from the hole, field parameters were not measured for the sample from $306 \mathrm{ft}$, and the sample from $345 \mathrm{ft}$ was not analyzed for tritium. 


\section{Drilling Notes}

Drilling notes and geophysical logs for the B206 Canyon borehole can be found at ftp://borehole.unavco.org/pub/borehole/B206/. Drilling began on June 14, 2008, and ceased on June 19, 2008. The maximum depth of the borehole (400 ft) was reached on June 16, 2008, with a bottom hole temperature of $81.2^{\circ} \mathrm{C}$ measured on June 17,2008 . The major water production zone is shown in table 6 . The driller noted one lost circulation zone at $142 \mathrm{ft}$, and zones of varying hardness as determined by drill bit penetration, throughout the borehole.

Table 6. Major water production zone in the B206 Canyon borehole, Yellowstone National Park, Wyoming.

\begin{tabular}{ccccc}
\hline Date & $\begin{array}{c}\text { Time } \\
\text { (Mountain } \\
\text { Daylight Time) }\end{array}$ & $\begin{array}{c}\text { Depth } \\
\text { (feet) }\end{array}$ & $\begin{array}{c}\text { Discharge } \\
\text { (gallons per } \\
\text { minute) }\end{array}$ & $\begin{array}{c}\text { Temperature } \\
\text { (degrees } \\
\text { Celsius) }\end{array}$ \\
\hline July 18, 2008 & $18: 29$ & 400 & 4 & 14.1 \\
\hline
\end{tabular}

The B206 Canyon borehole produced geothermal gas accumulations that field personnel measured, monitored, and mitigated. At 15:55 Mountain Daylight Time (MDT) on June 17,2008 , the following gas measurements were made using a Bacharach sensor: carbon dioxide $\left(\mathrm{CO}_{2}\right)$, greater than 60 percent; oxygen $\left(\mathrm{O}_{2}\right), 1.4$ percent; and hydrogen sulfide $\left(\mathrm{H}_{2} \mathrm{~S}\right)$, $21.5 \mathrm{ppm}$. Six hundred gallons of water taken from the Yellowstone River were pumped into the well. Approximately 1 hour after pumping the water into the well, no unusual gas concentrations were noted $2 \mathrm{ft}$ below the top of the surface casing. On June 18, 2008, after sitting overnight, however, high levels of geothermal gas (54-percent $\mathrm{CO}_{2}$ and $10.5 \mathrm{ppm}$ $\mathrm{H}_{2} \mathrm{~S}$ ) were measured in the casing and above the kelly bushing. The drillers pumped 500 gallons of water into the borehole and subsequently injected 32 bags of cement into the bottom of the hole. Drillers tagged the top of the cement at $266 \mathrm{ft}$ below ground level. High levels of geothermal gas were noted again $2 \mathrm{ft}$ below the top of the casing. The levels of geothermal gas at ground level and above the kelly bushing, however, were within safe margins, indicating that the gas flux was very low.

\section{B207 Madison Borehole}

\section{Location}

The B207 Madison borehole is located south and east of Madison Junction (fig. 11). The site, accessed by an NPS service road (not available for public access), is near a temporary storage building in an old gravel pit and materials storage area.

\section{General Geology}

The B207 Madison borehole occurs within the Yellowstone caldera (fig. 11). There is a complex geologic history associated with the formation of the Yellowstone caldera and Quaternary glaciation. In places, faults and fractures provide permeable pathways for heat and fluids to hydrothermally alter bedrock and various Quaternary sediments. Hydrothermal activity is visible at the surface near Madison Junction.

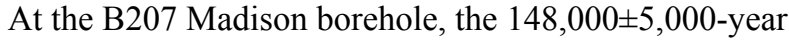
old Nez Perce Creek flow generally occurs east of the Firehole River (Christiansen and Blank, Jr., 1974; Christiansen, 2001). Christiansen and others (2007) estimated a thickness of $135 \mathrm{ft}$ for the Nez Perce Creek flow. Waldrop and Pierce (1975) mapped Pinedale-age till and small outcrops of rubble (less than $5 \mathrm{ft}$ ) on top of the Nez Perce Creek flow in the area. Other mapped rhyolite flows and tuffs in the area include the following units: the 114,000 $\pm 1,000$-year old West Yellowstone flow, the 380,000 $\pm 30,000$-year old Madison River Basalt, the 639,000 $\pm 2,000$-year old LCT (Lanphere and others, 2002; Abedini and others, 2007), and the 839,000 $\pm 8,000$-year old Harlequin Lake flow (Christiansen, 2001).

\section{Stratigraphy}

A preliminary field lithologic interpretation based on B207 Madison borehole cuttings is shown in table 7 with the following sequence: fill (0-7 ft), Nez Perce Creek flow (7-90 ft), a black rhyolite flow (90-145 ft), and the LCT (145 ft to bottom of hole).

Table 7. General stratigraphy and lithology for the B207 Madison borehole, Yellowstone National Park, Wyoming.

\begin{tabular}{|c|c|c|}
\hline Depth (feet) & Description & Comments \\
\hline $0-7$ & Fill & \\
\hline $7-90$ & Rhyolite & $\begin{array}{l}\text { Dark gray, vesicular, pale-brown water when washing cuttings at } 40-45 \text { feet; at } 75 \text { feet large angular rocks } \\
\text { coated with yellow color (Munsell Color: } 10 \text { YR } 7 / 6 \text { ) }\end{array}$ \\
\hline $90-145$ & Rhyolite and tuff & Black lava flow and tuff; irregular transition zone \\
\hline $145-400$ & Rhyolite tuff & $\begin{array}{l}\text { Pink to gray welded tuff, sucrosic tuff at } 240-245 \text { feet, phenocrysts of quartz and feldspar with minor } \\
\text { ferromagnesian minerals; rhyolite with flattened pumice at } 270-275 \text { feet; millimeter-scale flow banding at } \\
295-300 \text { feet, red and yellow colors on fracture planes at } 145-165 \text { feet; other fractures at } 279,298,339 \text {, } \\
347-350,370-375 \text {, and } 405-432 \text { feet }\end{array}$ \\
\hline $400-690$ & Rhyolite tuff & Harder to drill than above; gray cuttings, varying from coarse to fine \\
\hline
\end{tabular}




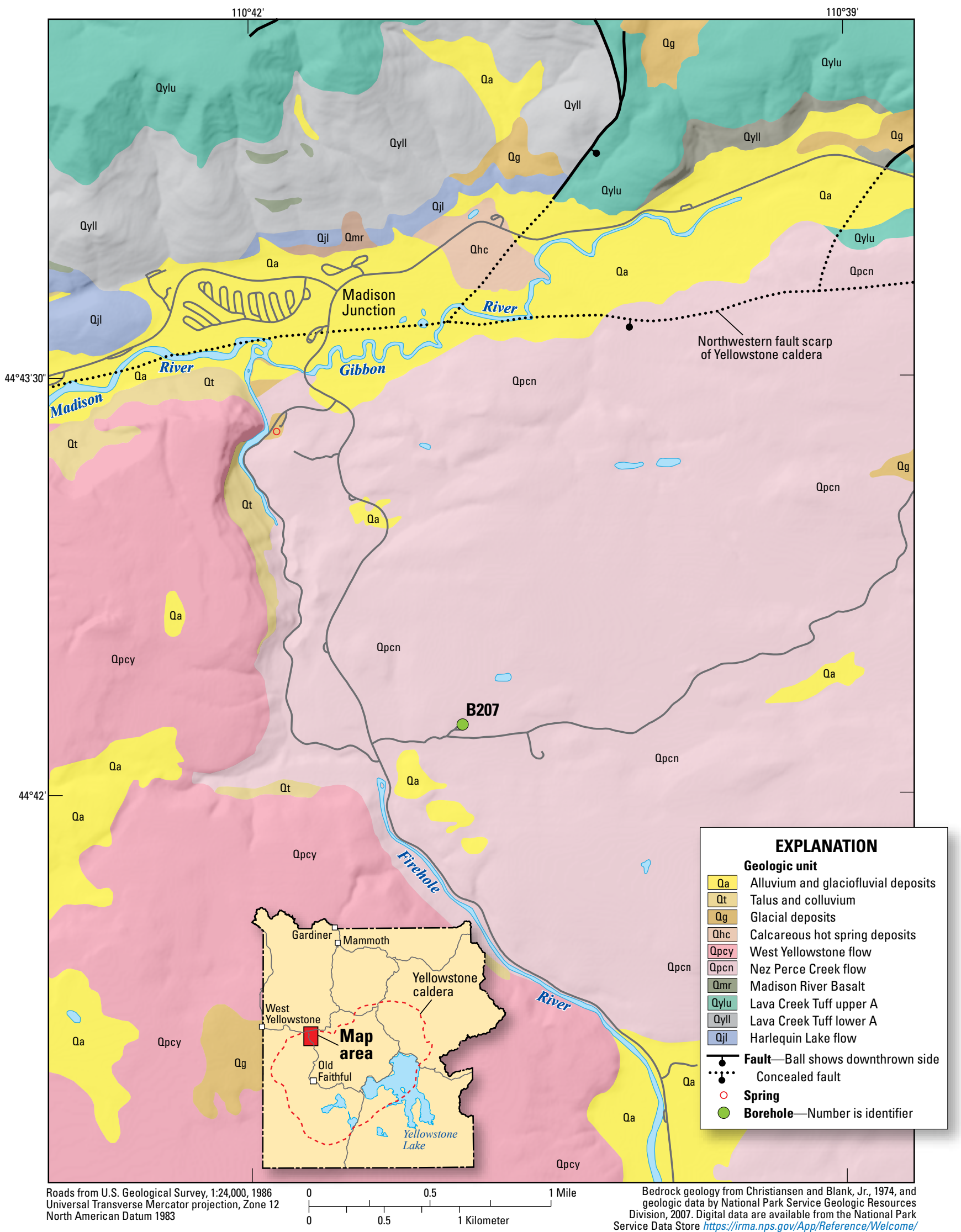

Figure 11. Bedrock geology in the vicinity of the B207 Madison borehole, Yellowstone National Park, Wyoming. 


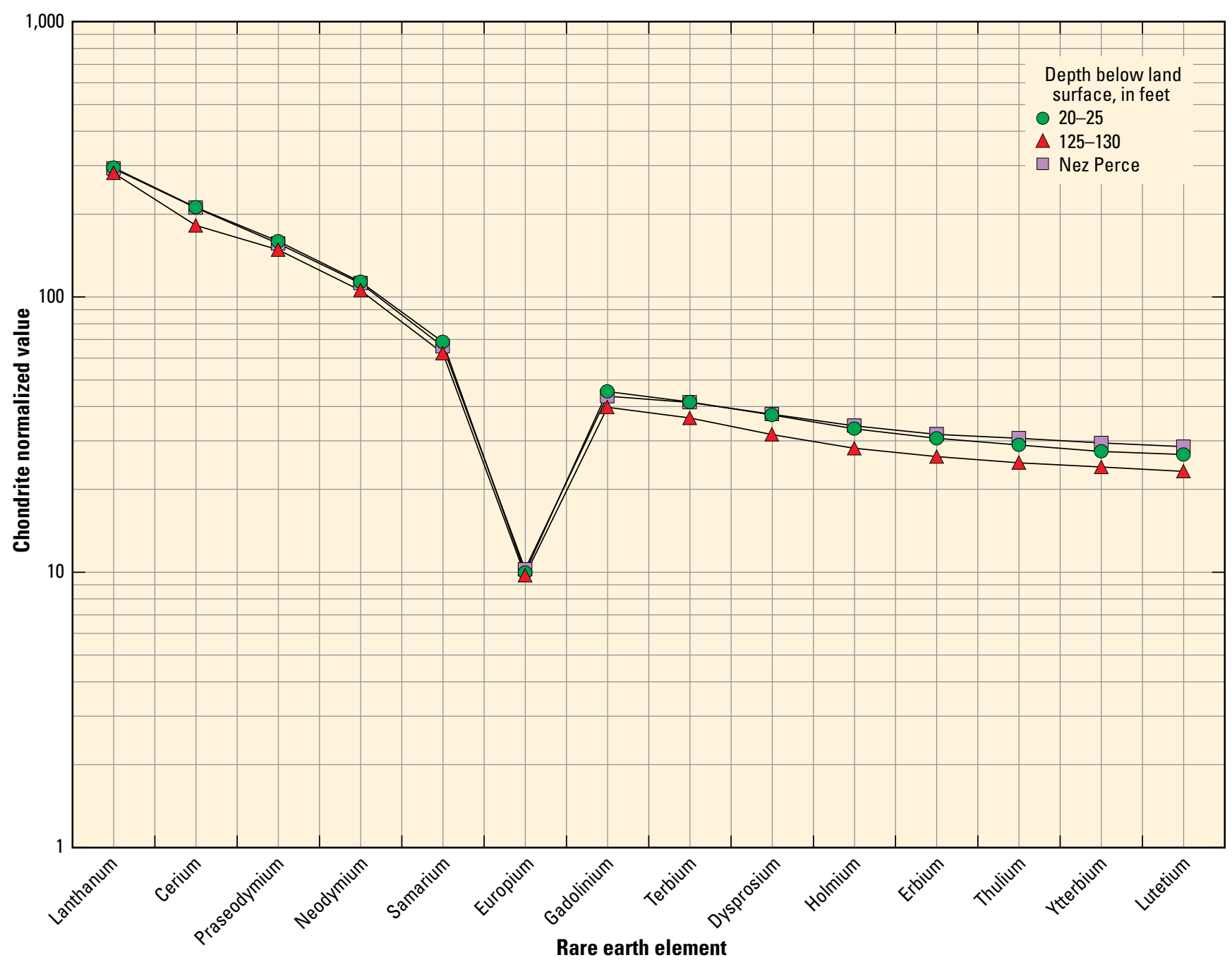

Figure 12. Rare earth element chemistry using chondrite normalized values of Boynton (1985) for selected depths in the upper part of the B207 Madison borehole and for a reference sample from the Nez Perce Creek flow (Nez Perce), Yellowstone National Park, Wyoming.

\section{Geochemical Analysis of Cuttings}

Cuttings analyzed for REE geochemistry from the B207 Madison borehole confirmed that the borehole went through the Nez Perce Creek flow and the LCT. At a depth of 20-25 ft, the REE geochemistry of the cuttings is consistent with the REE geochemistry of the reference sample from the Nez Perce Creek flow (table 2 and fig. 12). The REE geochemistry at the 125-130-ft depth, however, differs from the Nez Perce Creek flow reference sample for the REEs gadolinium, terbium, dysprosium, holmium, erbium, thulium, ytterbium, and lutetium. The consistent set of REE curves from the $240-655-\mathrm{ft}$ interval indicates that the B207 Madison borehole penetrated the LCT (fig. 13). The REE geochemistry of the borehole cuttings is similar to the REE geochemistry of an LCT-A reference sample from Gibbon Canyon (Christiansen and Blank, Jr., 1974; table 2). The reference sample is similar for some REEs (lanthanum, cerium, praseodymium, neodymium and samarium) but not for other REEs (gadolinium, terbium, dysprosium, holmium, terbium, thulium, ytterbium, and lutetium). The slight decrease in cerium concentrations at 380 and 440 $\mathrm{ft}$ is consistent with redox reactions (Piper and Bau, 2013) and hydrothermal processes within the borehole (Marfil and Maiza, 2012).

Concentrations of zirconium and niobium also can be used to differentiate the LCT within the B207 Madison borehole (fig. 14). Von Stauffenberg (2015) states that "compositional trends clearly distinguish between members A and B, as well as identification of the lower and upper sub units of each member." For the upper LCT-A, Von Stauffenberg (2015) identified a zirconium concentration between 185 and 300 ppm and a niobium concentration between 49 and $51 \mathrm{ppm}$. Incorporating published geochemistry for the LCT (LCT-A Upper BV, Bindeman and others, 2001; LCT-A Upper RC, Christiansen, 2001; LCT-A Upper JS, Von Stauffenberg, 2015), and geochemical data from this study (LCT G and LCT B O; table 2), 


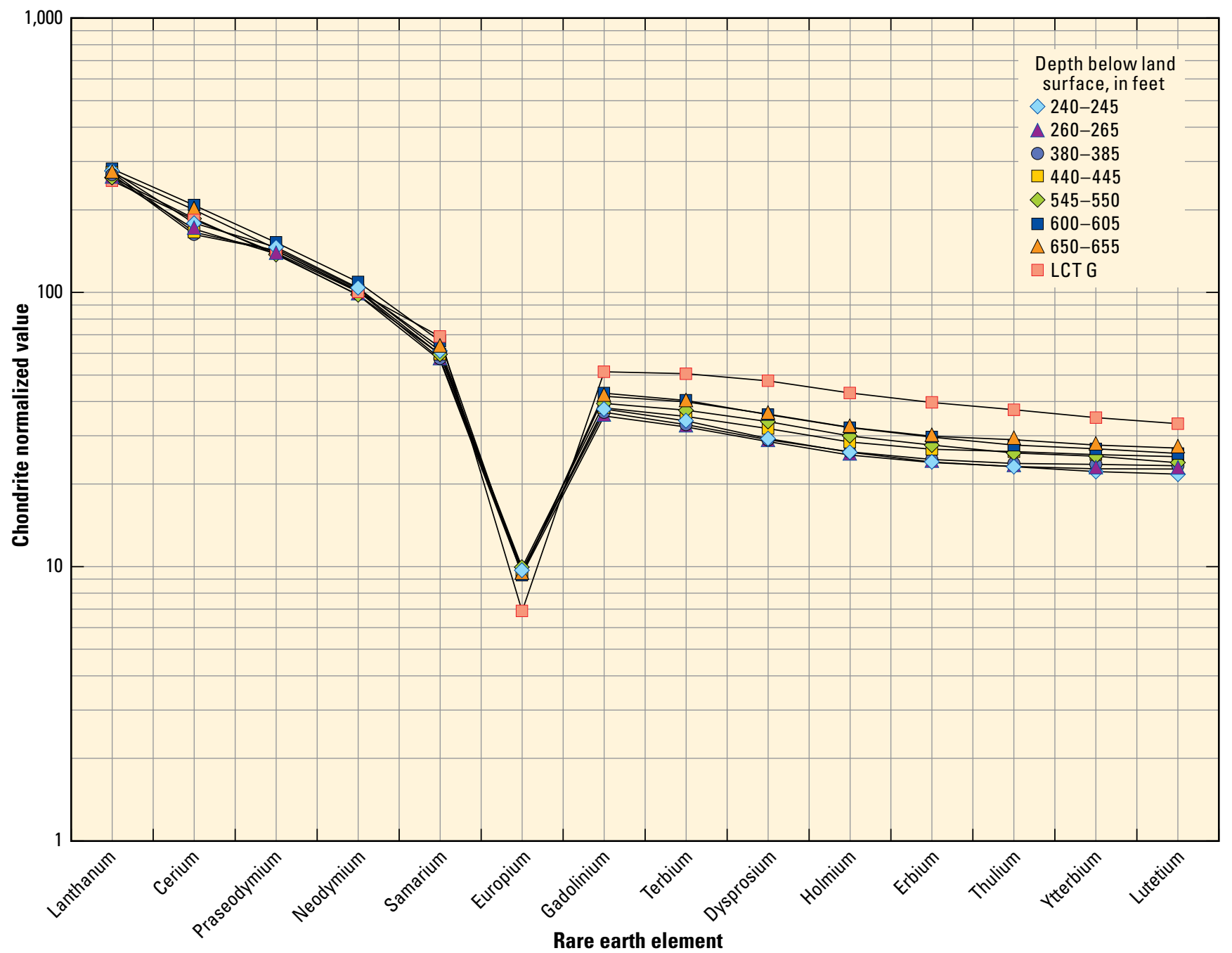

Figure 13. Rare earth element chemistry using chondrite normalized values of Boynton (1985) for selected depths in the lower part of the B207 Madison borehole and for a reference sample from the Lava Creek Tuff (LCT G) in Gibbon Canyon, Yellowstone National Park, Wyoming.

figure 14 shows that the lower B207 Madison borehole samples plot between the LCT-A Upper BV at Tuff Cliffs and the LCT-A Upper RC vitrophyre on Mount Jackson. Below $495 \mathrm{ft}$, the Madison borehole values plot to the right of LCT-A Upper JS data from the Purple Mountain summit (Von Stauffenberg, 2015). From 240-445 ft in depth, the Madison borehole values plot to the left of the LCT-A Upper JS data. Future petrologic and geochemical work may provide additional understanding of the LCT within the B207 Madison borehole.

\section{Water Chemistry}

Water samples were collected from depths of 245, 343, and $415 \mathrm{ft}$ below land surface during drilling of the B207 Madison borehole (appendix 2). Water temperature increased from 17.8 to $21.2{ }^{\circ} \mathrm{C}$ between 245 and $415 \mathrm{ft}$, but samples were not collected below $415 \mathrm{ft}$ because of the availability of personnel. Concentrations of dissolved constituents were generally similar among the three samples with the exception of sulfate and calcium, which increased in the water sample collected at $415 \mathrm{ft}$ (appendix 2). Stable-isotope values ( $\delta \mathrm{D},-145$ to -147 $\%$ and $\delta^{18} \mathrm{O},-19.4$ to $-19.6 \%$ ) are similar to values reported for precipitation in Yellowstone $(\delta \mathrm{D},-115$ to $-153 \%$ and $\delta^{18} \mathrm{O},-15.2$ to $-20.2 \%$ ) (Kharaka and others, 2002). Tritium was present in two of the samples and decreased with depth.

\section{Drilling Notes}

Drilling notes and geophysical logs for the B207 Madison borehole can be found at ftp://borehole.unavco.org/pub/borehole/B207/. Drilling began on October 3, 2007, and ceased on October 13, 2007, at a depth of $691 \mathrm{ft}$ with a bottom hole temperature of $29.7^{\circ} \mathrm{C}$ measured on October 14, 2007. Major water production zones are shown in table 8. Additionally, the driller noted a fractured zone from 575 to $585 \mathrm{ft}$ and zones of varying hardness based on drill bit penetration rates. 


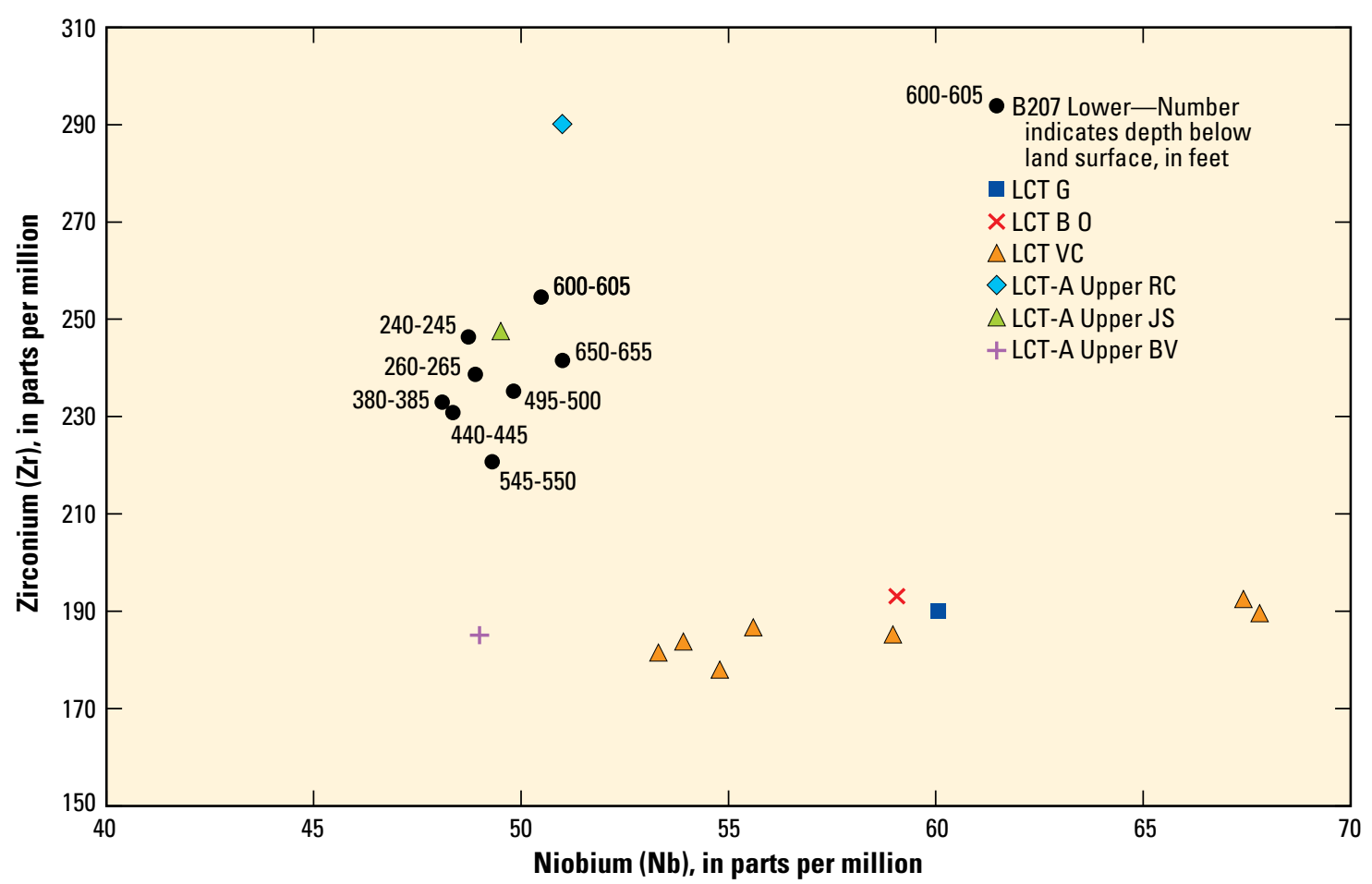

Figure 14. Concentrations of zirconium (Zr) versus niobium (Nb) for lower B207 Madison borehole samples, reference samples of the Lava Creek Tuff (LCT) from this study (LCT B 0 and LCT G), a sample (LCT-A Upper RC) from Christiansen (2001, sample 74Y-180B), a sample (LCT-A Upper BV) from Bindeman and Valley (2001, sample LCT3-A), and for samples from Von Stauffenberg (2015, LCT-A Upper JS and LCT VC).

Table 8. Major water production zones and temperature in the B207 Madison borehole, Yellowstone National Park, Wyoming.

$[>$, greater than]

\begin{tabular}{lcccc}
\hline \multicolumn{1}{c}{ Date } & $\begin{array}{c}\text { Time } \\
\text { (Mountain } \\
\text { Daylight Time) }\end{array}$ & $\begin{array}{c}\text { Depth } \\
\text { (feet) }\end{array}$ & $\begin{array}{c}\text { Discharge } \\
\text { (gallons per } \\
\text { minute) }\end{array}$ & $\begin{array}{c}\text { Temperature } \\
\text { (degrees } \\
\text { Celsius) }\end{array}$ \\
\hline October 4, 2007 & $13: 58$ & 225 & 30 & 16.7 \\
\hline October 4, 2007 & $17: 08$ & 305 & $45-50$ & 18.6 \\
October 5, 2007 & $11: 36$ & 345 & $>200$ & 18.3 \\
\hline October 9, 2007 & $16: 06$ & 445 & 170 & 9.3 \\
\hline October 12, 2007 & $17: 00$ & 515 & 85 & 22.0 \\
\hline October 13, 2007 & $15: 00$ & 675 & 80 & 22.1 \\
\hline
\end{tabular}

\section{B208 Lake Borehole}

\section{Location}

The B208 Lake borehole is located southwest of the NPS housing and maintenance facilities near Lake Village (fig. 15). An NPS service road that accesses the horse corrals provides access (not available to the public) to the B208 Lake borehole.

\section{General Geology}

At the B208 Lake borehole, alluvial and glaciolacustrine sediments overlie rhyolite flows (Christiansen and Blank, Jr., 1975; Richmond, 1977; Christiansen and others, 2007). On the surface, Richmond (1977) mapped buff to gray sandy gravel or gravelly sand ice-contact sediments, approximately 20 to $50 \mathrm{ft}$ in thickness. Near the B208 Lake borehole, the $173,000 \pm 11,000$-year old West Thumb flow occurs on the hillside (Christiansen and Blank, Jr., 1975; Christiansen and others, 2007). The 153,000 $\pm 2,000$-year old Elephant Back flow (Christiansen, 2001) overlies the West Thumb flow. Recent work by Watts and others (2012) on zircons from Central Plateau rhyolites such as the Elephant Back flow $(174,000 \pm 23,000$ years) and the Tuff of Bluff Point $(176,000 \pm 21,000$ years) provides uranium-thorium and uranium-lead ages for these rhyolitic units.

\section{Stratigraphy}

The field analysis of cuttings from the B208 Lake borehole indicated that it penetrated various sediments from 0 to $195 \mathrm{ft}$ (table 9). From 0-60 ft, cuttings were primarily sandy sediments underlain by sediments containing pumice and tephra between 60 and $75 \mathrm{ft}$. From $75-150 \mathrm{ft}$, the cuttings contained more volcanic debris than the overlying units: obsidian was visible in cuttings from $85-120 \mathrm{ft}$ and at $150 \mathrm{ft}$, the cuttings appeared glassy and light gray. From 195-250 ft, the cuttings indicated that the borehole had penetrated a lithic tuff. From $250-355 \mathrm{ft}$, the borehole penetrated a blue-gray rhyolite flow and tuff with observable phenocrysts of quartz and feldspar. Brown, varved sediments were encountered at 290 $\mathrm{ft}$. From 355-610 ft, cuttings indicated that a rhyolite flow had been penetrated. From $610-700 \mathrm{ft}$, the cuttings consisted 


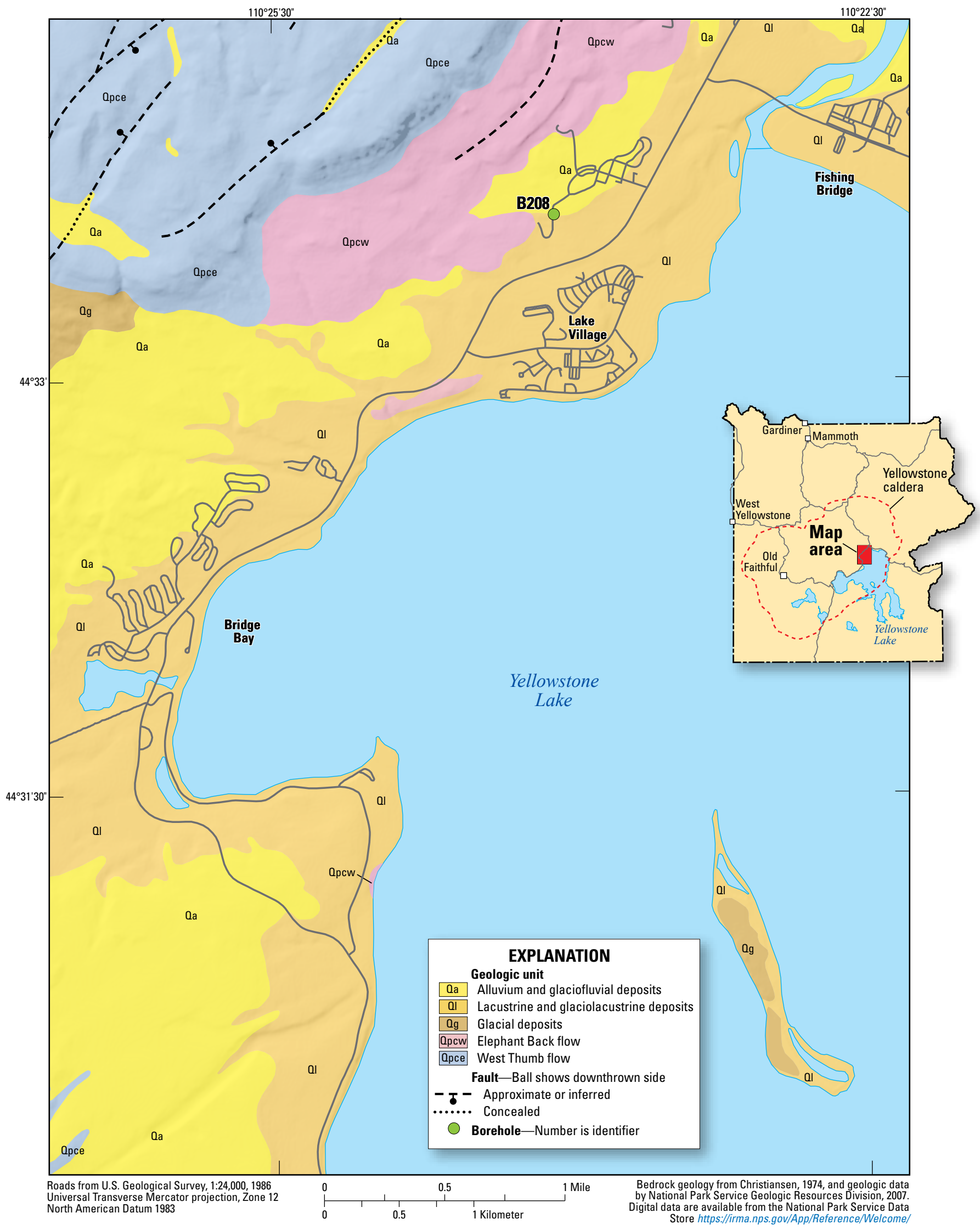

Figure 15. Bedrock geology in the vicinity of the B208 Lake borehole, Yellowstone National Park, Wyoming. 
Table 9. General stratigraphy and lithology for the B208 Lake borehole, Yellowstone National Park, Wyoming.

\begin{tabular}{|c|c|c|}
\hline Depth (feet) & Description & Comments \\
\hline $0-195$ & Sediments & $\begin{array}{l}\text { Sandy pale-brown sediments from } 0-60 \text { feet; tephra-rich sediments with pumice from } 60-75 \text { feet; from } \\
85-120 \text { feet, obsidian in cuttings; from } 130-150 \text { feet, cuttings are light gray (Munsell Color: } 10 \mathrm{YR} 7 / 1 \text { ) and } \\
\text { glassy }\end{array}$ \\
\hline $250-355$ & $\begin{array}{l}\text { Blue-gray rhyolite with } \\
\text { phenocrysts and tuff }\end{array}$ & $\begin{array}{l}\text { Blue-gray color (Munsell Color:Gley } 25 / 1 \text { ); altered at 250-255 feet; brown, varved sediments at } 290 \text { feet; } \\
\text { bleached zone from 310-355 feet }\end{array}$ \\
\hline $400-610$ & Gray to blue-gray rhyolite & Bit change at 400 feet; sugary texture at $485-490$ feet; obsidian and vitrophyre at $565-570$ feet \\
\hline $610-800$ & Tuffaceous sediment & $\begin{array}{l}\text { Tephra; glassy, crystal-rich, euhedral quartz bipyramids, brown-black obsidian, and aerodynamically } \\
\text { shaped glass }\end{array}$ \\
\hline
\end{tabular}

of unconsolidated tuffaceous sediments with brown-black obsidian. From $700 \mathrm{ft}$ to the bottom of the hole at $800 \mathrm{ft}$, the cuttings contained euhedral quartz bipyramids and aerodynamically shaped volcanic glass. Table 9 summarizes the B208 Lake borehole stratigraphy.

\section{Geochemical Analysis of Cuttings}

Cuttings from the B208 Lake borehole analyzed for REE geochemistry confirm that the West Thumb flow, the Tuff of Bluff Point, and tuffaceous sediments underlie the upper sedimentary sequence. At a depth of 95-100 ft, the REE curve of the cuttings is similar to the REE curve for the Tuff of Bluff Point reference sample (fig. 16). From 140-410 ft, the REE curve is similar to the West Thumb flow reference sample (figs. 16 and 17). From 455-550 ft, the REE curves of coarse cuttings are similar to the Tuff of Bluff Point (fig. 17). From 600-740 ft, the REE concentrations for the unconsolidated, glassy, and crystal-rich basal unit differ from the overlying rhyolites. On the basis of the REE geochemistry, the B208 Lake borehole penetrated a sequence of rhyolite flows and tuff associated with the formation of the West Thumb caldera. However, continued work on the unconsolidated 100-ft-thick basal unit may yield additional geologic information.

\section{Water Chemistry}

Water samples were collected from 306, 402, 550, and $800 \mathrm{ft}$ below land surface during drilling of the B208 Lake borehole (appendix 2). The water temperature increased about $2{ }^{\circ} \mathrm{C}$ between 306 and $800 \mathrm{ft}$. Dissolved constituents also varied over a narrow range, indicating little change in water chemistry with depth at this site. The analysis of a water sample collected from a nearby spring (a source of water to the Lake Village area) had field parameters and concentrations of dissolved constituents similar to the B208 Lake borehole water.

Stable-isotope values for water from the B208 Lake borehole are similar to values reported for precipitation throughout the region ( $\delta \mathrm{D},-115$ to $-153 \%$ and $\delta^{18} \mathrm{O},-15.2$ to $-20.2 \%$ ) (Kharaka and others, 2002) and are lighter than values of samples from Yellowstone Lake $\left(\delta \mathrm{D},-124 \%\right.$ and $\delta^{18} \mathrm{O}$, $-15.6 \%$ ) (appendix 2). Tritium concentrations from samples collected at depths of 306 and $402 \mathrm{ft}$ (11.7 and 11.6 TU) are similar to the sample collected from the nearby spring (12.8 TU).

\section{Drilling Notes}

Drilling notes and geophysical logs for the B208 Lake borehole can be found at ftp://borehole.unavco.org/pub/borehole/B208/. Drilling began on October 15, 2007, and ceased on October 20, 2007, at a depth of $800 \mathrm{ft}$, with a bottom hole temperature of $19.6^{\circ} \mathrm{C}$ measured on October 22, 2007. Major water production zones are shown in table 10 .

\section{Grant 1 Borehole}

Two boreholes were drilled in the Grant Village area of YNP (fig. 18). The first borehole, Grant 1, was abandoned because of high temperature $\left(91.8^{\circ} \mathrm{C}\right)$ at a depth of $209 \mathrm{ft}$. A second site, B944 Grant, was selected and a borehole was successfully drilled. Results from both boreholes are presented in the following sections.

Table 10. Major water production zones and temperature in the B208 Lake borehole, Yellowstone National Park, Wyoming.

\begin{tabular}{lcccc} 
[>, greater than; NM, not measured] & & & \\
\hline Date & $\begin{array}{c}\text { Time } \\
\text { (Mountain } \\
\text { Daylight Time) }\end{array}$ & $\begin{array}{c}\text { Depth } \\
\text { (feet) }\end{array}$ & $\begin{array}{c}\text { Discharge } \\
\text { (gallons per } \\
\text { minute) }\end{array}$ & $\begin{array}{c}\text { Temperature } \\
\text { (degrees } \\
\text { Celsius) }\end{array}$ \\
\hline October 16, 2007 & $17: 14$ & 306 & 75 & 8.6 \\
\hline October 17, 2007 & $13: 30$ & 365 & 160 & $\mathrm{NM}$ \\
\hline October 17, 2007 & $15: 09$ & 393 & 175 & 7.9 \\
\hline October 20, 2007 & $9: 25$ & 550 & $75-100$ & 9.7 \\
\hline October 20, 2007 & $14: 40$ & 800 & $>100$ & 10.1 \\
\hline
\end{tabular}




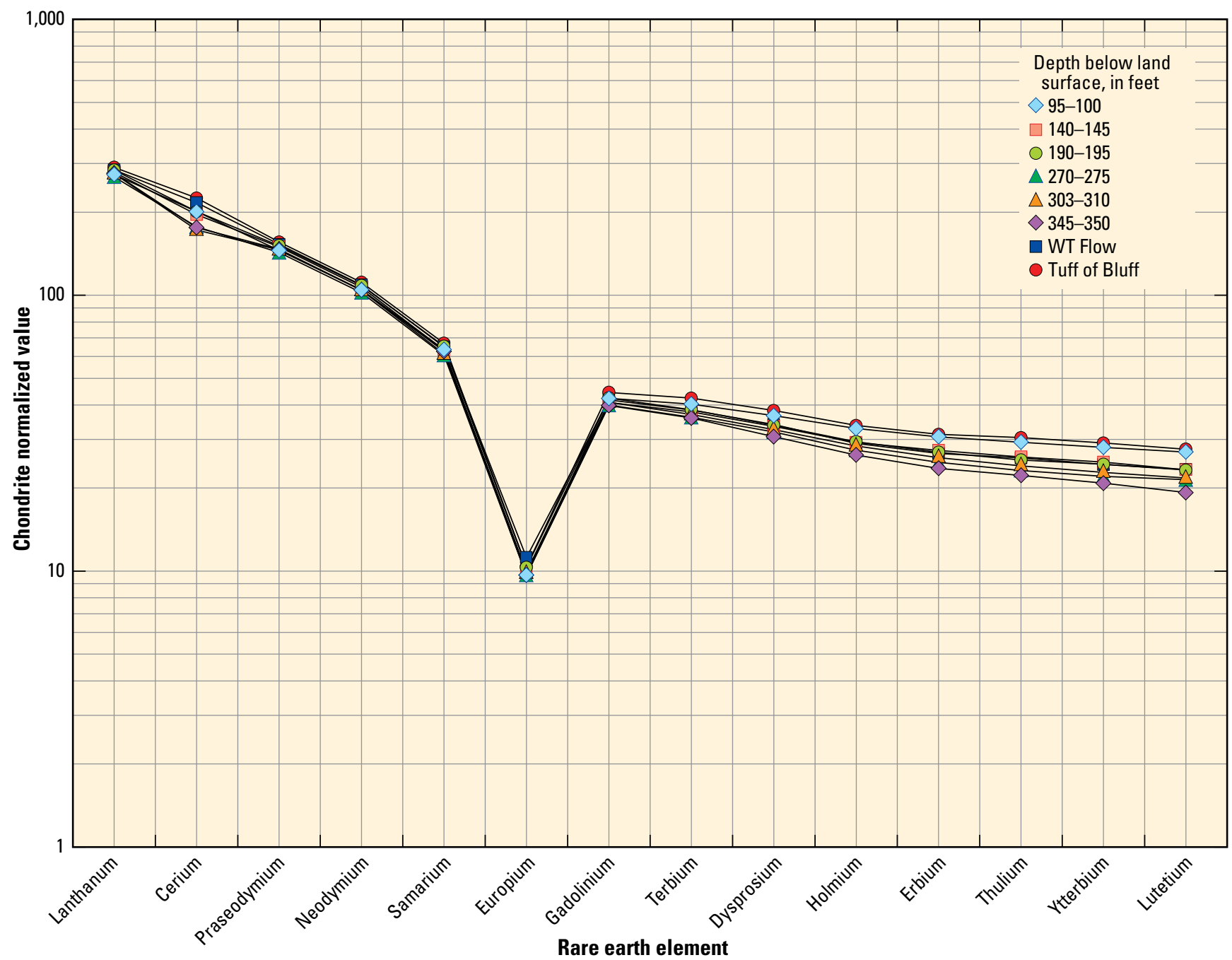

Figure 16. Rare earth element chemistry using chondrite normalized values of Boynton (1985) for selected depths in the upper part of the B208 Lake borehole and for reference samples from the West Thumb flow (WT Flow) and Tuff of Bluff Point (Tuff of Bluff), Yellowstone National Park, Wyoming.

\section{Location}

The Grant 1 borehole is located southwest of the West Thumb of Yellowstone Lake (fig. 18). An NPS service road northwest of Grant Village provided access (non-public) to the borehole.

\section{General Geology}

The Grant Village area, the abandoned Grant 1 borehole, and the B944 Grant borehole occur within the Yellowstone caldera (fig. 18) and adjacent to the 173,000-year old West Thumb caldera. There is a complex geologic history associated with the formation of the Yellowstone caldera, the West Thumb caldera, and Quaternary glaciation. Faults and fractures provide permeable pathways for heat and fluids to hydrothermally alter bedrock and various sediments. A hydrothermal explosion crater (4,000 to 6,000 years ago) is now occupied by Duck Lake, which is surrounded by hydrothermal explosion deposits (Christiansen and others, 2007). Current hydrothermal activity is visible at the surface (West Thumb Geyser Basin), and may underlie glacial sediments or exist in the shallow subsurface.

Near the Grant 1 borehole, lacustrine or glaciolacustrine sediments are mapped overlying rhyolitic rocks near the West Thumb of Yellowstone Lake (Richmond, 1973; Christiansen, 1974; Christiansen and others, 2007). In this area, Richmond (1973) described gray to blue-gray, laminated to massive, silts and sands deposited in an open-lake environment as well as blue-gray, ice-dammed silts. The open-lake sediments vary from $20-40 \mathrm{ft}$ in thickness and form terraces 35,40 , and $60-65 \mathrm{ft}$ above lake level around the West Thumb of Yellowstone Lake. The ice-dammed lake silts and sands may be locally varved and form terraces at 80 , 90, 110, and $160 \mathrm{ft}$ above the lake. The Elephant Back flow $(153,000 \pm 2,000$ years), Dry Creek flow $(166,000 \pm 9,000$ years), Aster Creek flow (155,000 $\pm 3,000$ years), and Tuff of Bluff Point (173,000 $\pm 11,000$ years) occur around the West 
Thumb of Yellowstone Lake (Christiansen, 2001; Christiansen and others, 2007). Christiansen (2001) proposed that the Tuff of Bluff Point was "an explosive, late-stage eruption from the Dry Creek vent" and that the Aster Creek flow partially buries the southeastern portion of the West Thumb caldera. Christiansen and others (2007) describe the Tuff of Bluff Point as a "multiple-flow cooling unit of ash-flow tuff" that can be non-welded, partly welded, and glassy.

\section{Stratigraphy}

A preliminary stratigraphic interpretation of the Grant 1 borehole (table 11) indicates the following sequence: glacial sediments from $0-20 \mathrm{ft}$, gray-green tuffaceous sediments from 20-45 ft, non-welded tuff and blue-gray rhyolite from 45-105 $\mathrm{ft}$, and altered blue-gray rhyolite from 105-200 ft. Intermixed green sediments and rhyolite probably occur from 50-60 ft.

\section{Geochemical Analysis of Cuttings}

Two geologic units were encountered in the Grant 1 borehole: (1) a green, compacted, tuffaceous sediment of intermediate chemical composition at $20-45 \mathrm{ft}$, suggestive of an andesitic Absaroka provenance, and (2) the Tuff of Bluff Point. The REE geochemistry of samples from 55-60, 85-90, and 200-205 ft within the Grant 1 borehole is similar to the REE geochemistry of the Tuff of Bluff Point (fig. 19). Pritchard's (2011) geochemical analyses of glass (CJP08 G) and tuff (CJP08 T) are consistent with the Tuff of Bluff Point reference sample analyzed for this study (fig. 19).

\section{Water Chemistry}

One water sample was collected from the Grant 1 borehole at a depth of $209 \mathrm{ft}$ below land surface. The water temperature of the sample was $53{ }^{\circ} \mathrm{C}$ and the $\mathrm{pH}$ was 8.9. Three hours later, the insitu bottom hole temperature was $91.8^{\circ} \mathrm{C}$. The

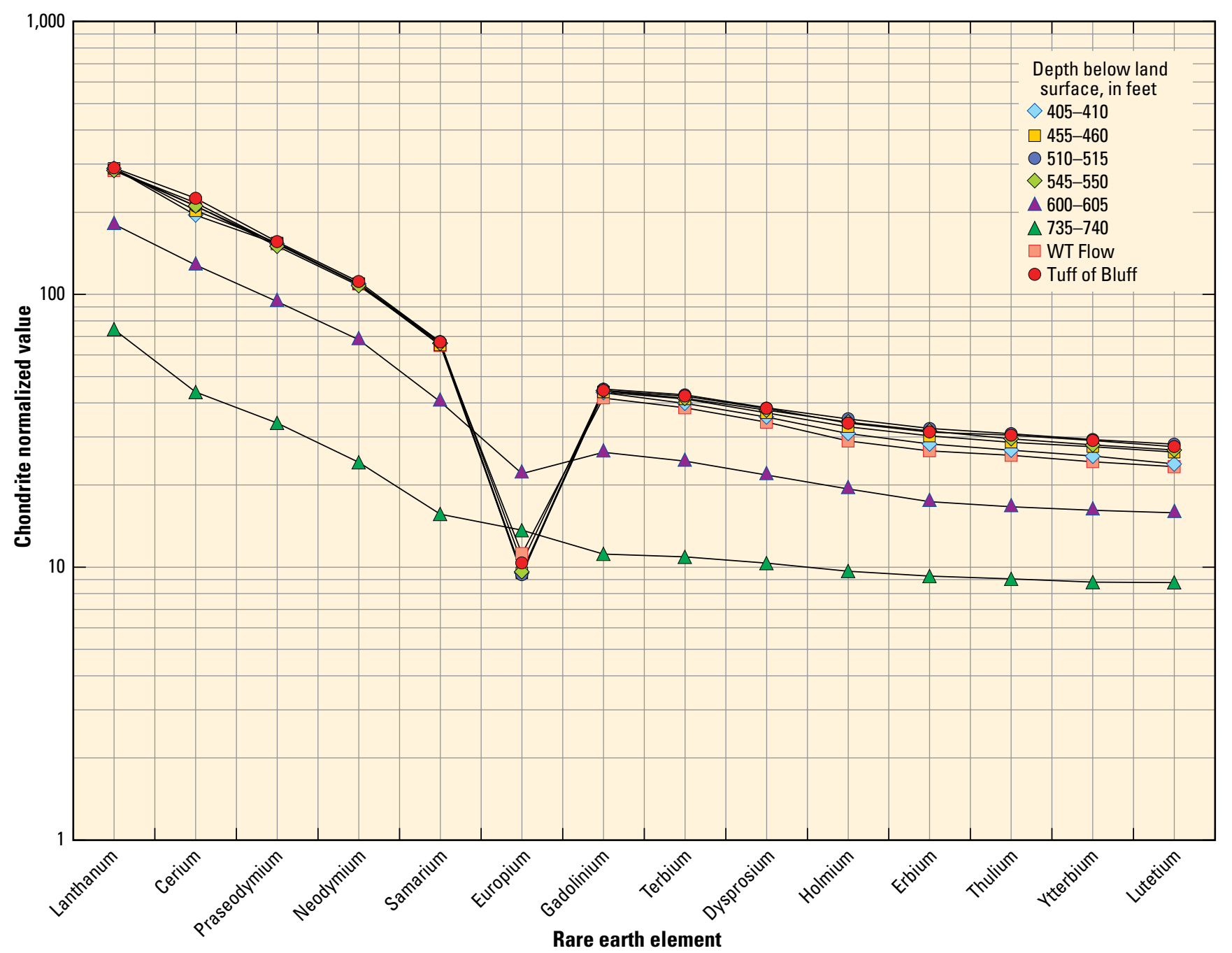

Figure 17. Rare earth element chemistry using chondrite normalized values of Boynton (1985) for selected depths in the lower part of the B208 Lake borehole and for reference samples from the West Thumb flow (WT Flow) and Tuff of Bluff Point (Tuff of Bluff), Yellowstone National Park, Wyoming. 


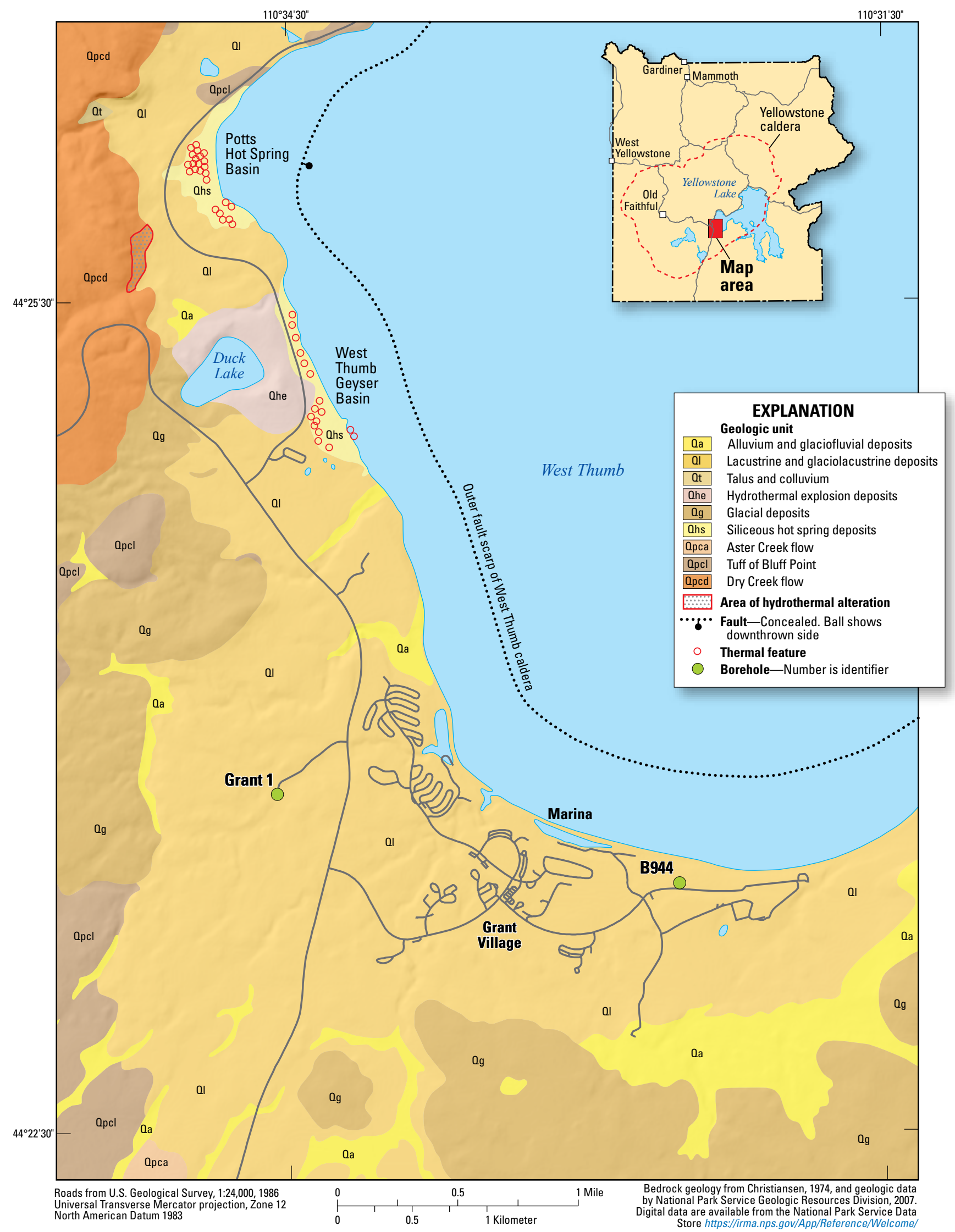

Figure 18. Bedrock geology in the vicinity of the Grant 1 and B944 Grant boreholes, Yellowstone National Park, Wyoming. 


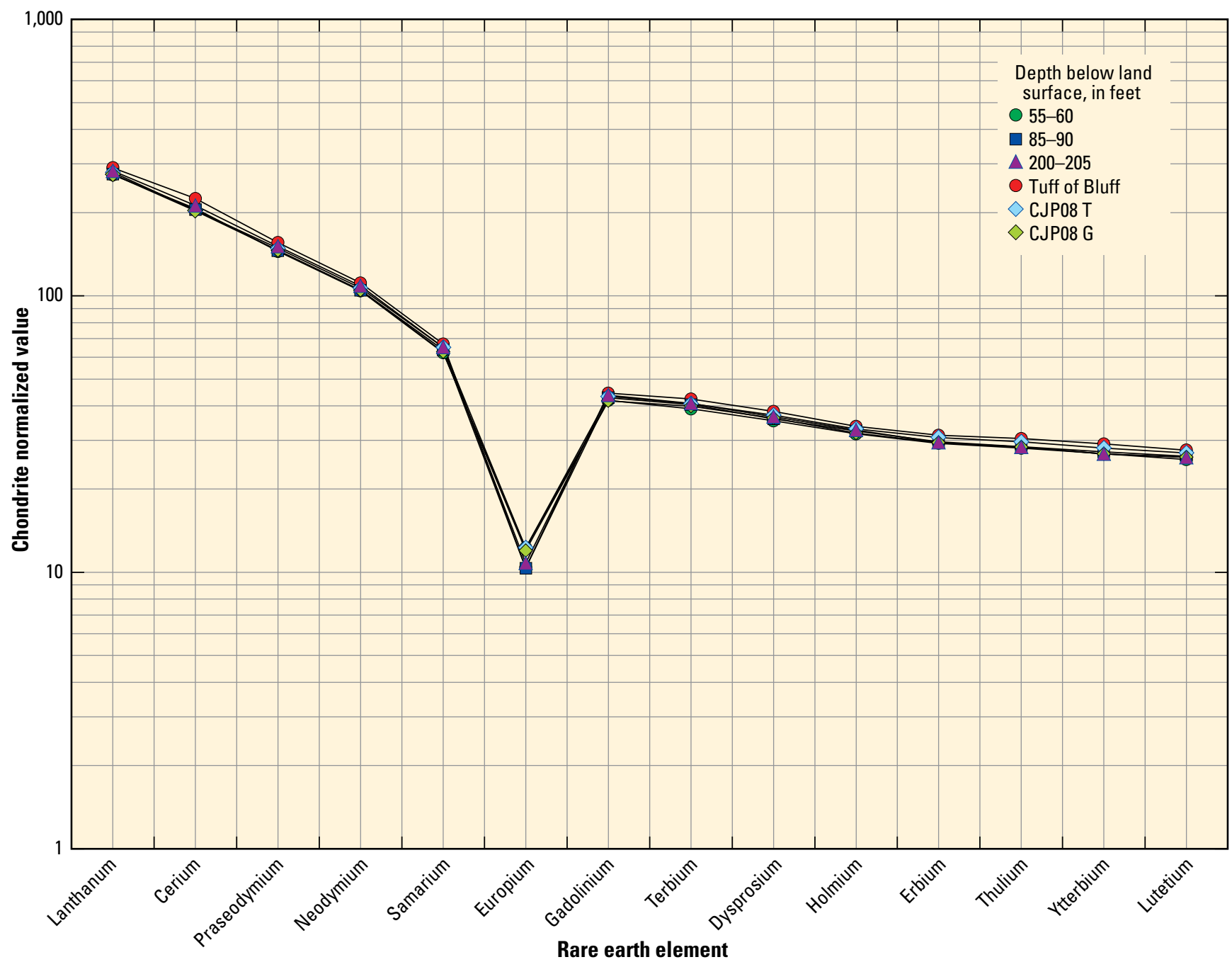

Figure 19. Rare earth element chemistry using chondrite normalized values of Boynton (1985) for selected depths in the Grant 1 borehole and for reference samples from the Tuff of Bluff Point (Tuff of Bluff, this study), and the Tuff of Bluff Point from Pritchard (2011, CJP08 G and CJP08 T), Yellowstone National Park, Wyoming.

Table 11. General stratigraphy and lithology for the Grant 1 borehole, Yellowstone National Park, Wyoming.

\begin{tabular}{|c|c|c|}
\hline Depth (feet) & Description & Comments \\
\hline $0-20$ & $\begin{array}{l}\text { Moist, yellow-brown pebble-rich } \\
\text { silty sand }\end{array}$ & Hammer bit used in drilling entire borehole \\
\hline $20-45$ & Gray-green sediments and tuff & $\begin{array}{l}\text { Glass-rich, light-gray tuff with clasts of rounded obsidian; some faceted pebbles; varves observed at } \\
35 \text { feet; probable metal sulfides at } 40-45 \text { feet }\end{array}$ \\
\hline $45-105$ & Tuff and blue-gray rhyolite & $\begin{array}{l}\text { Vitrophyric from } 45-60 \text { feet; } 1 \text { gallon per minute at } 55 \text { feet; flow-banding at } 100 \text { feet with green } \\
\text { mudstone }\end{array}$ \\
\hline $105-200$ & Altered blue-gray rhyolite & $\begin{array}{l}\text { Rhyolite with sulfides at } 135 \text { feet; jasper-red rhyolite/tuff at } 153 \text { feet; darker blue-gray rhyolite from } \\
195-200 \text { feet }\end{array}$ \\
\hline
\end{tabular}

lower sample temperature is likely due to air lifting the water from the borehole with the drill rig. The high temperature, $\mathrm{pH}$, and elevated concentrations of a number of constituents (bicarbonate, fluoride, chloride, sulfate, potassium, and sodium) are indicative of hydrothermal waters. The water sample was also tritiated (9.0 TU) (appendix 2).

\section{Drilling Notes}

Drilling notes for the Grant 1 borehole are included with the B944 Grant borehole data and can be accessed at ftp://borehole. unavco.org/pub/borehole/B944/. Drilling began on June 24, 2008 , and ceased on June 25, 2008, at a depth of $206 \mathrm{ft}$ with a bottom hole temperature of $92.0^{\circ} \mathrm{C}$ measured on October 28, 


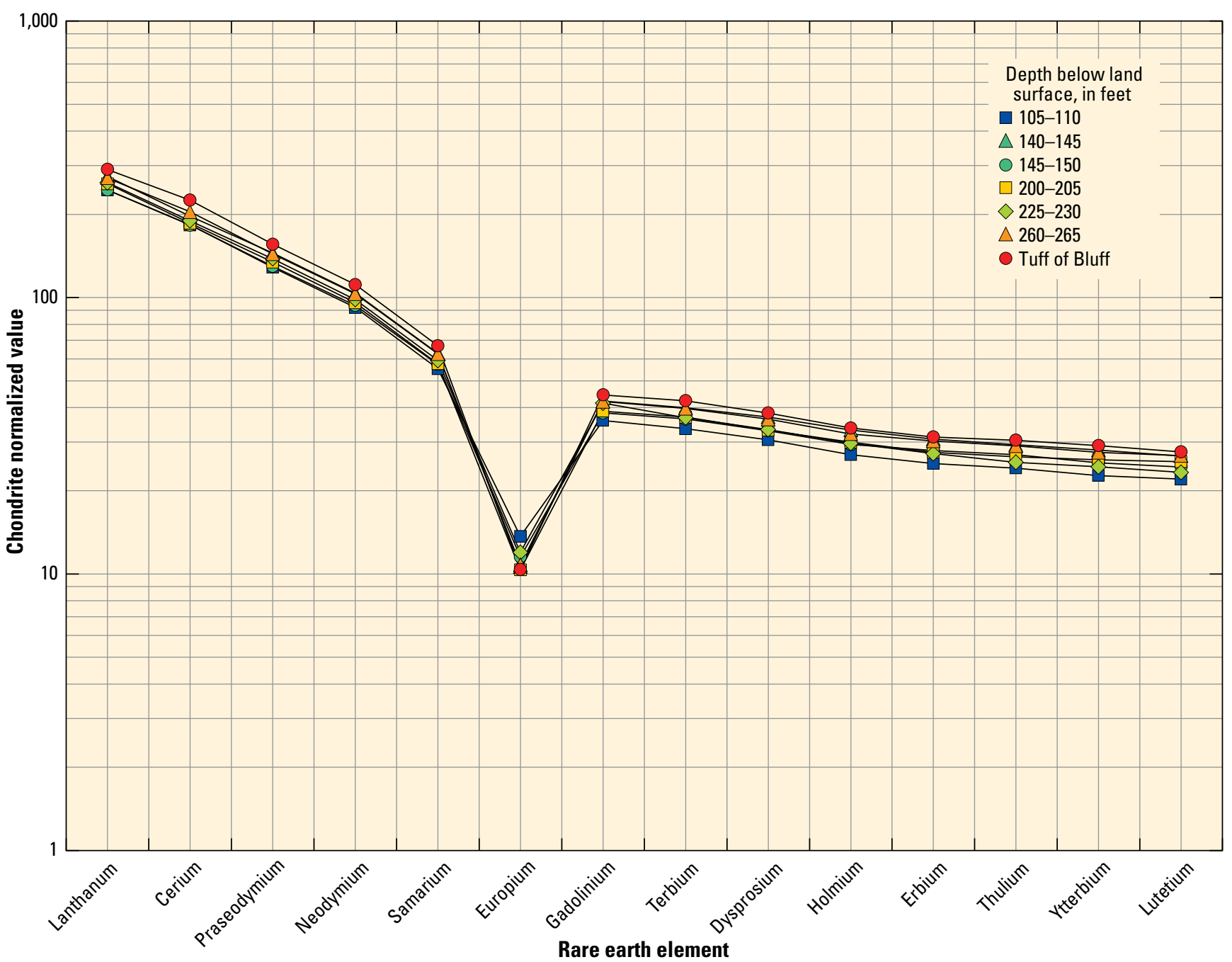

Figure 20. Rare earth element chemistry using chondrite normalized values of Boynton (1985) for selected depths in the upper part of the B944 Grant borehole and for a reference sample from the Tuff of Bluff Point (Tuff of Bluff), Yellowstone National Park, Wyoming.

2008. The greatest water production was $2 \mathrm{gal} / \mathrm{min}$ at $206 \mathrm{ft}$ on June 24, 2008. Zones of varying color and hardness were noted in this hole. Because the Grant 1 drilling site was too shallow $(206 \mathrm{ft})$ and too hot $\left(92.0^{\circ} \mathrm{C}\right)$ for a borehole strainmeter installation, the hole was abandoned and geophysical logs were not run.

\section{B944 Grant Borehole}

\section{Location}

The B944 Grant borehole is located south of the West Thumb of Yellowstone Lake (fig. 18). An NPS service road near the Grant Village Marina provided non-public access to the borehole.

\section{General Geology}

The geology of the B944 Grant borehole area is discussed in the "General Geology" section for the abandoned Grant 1 borehole.

\section{Stratigraphy}

The approximately 500-ft deep B944 Grant borehole penetrated a greater thickness of sediments, rhyolites, chaotic tuff, and welded tuff than was encountered at the Grant 1 borehole. The upper $200 \mathrm{ft}$ of sediments and rocks are similar to those encountered at the Grant 1 borehole. In the first $100 \mathrm{ft}$, pale-brown, pebble-rich sands (55 ft thick) and gray-green sediments (39 ft thick) were encountered (table 12); these sediments compose the terraces overlooking the West Thumb of Yellowstone Lake. Below the sediments, the borehole penetrated the glassy top of a rhyolite flow at approximately $94 \mathrm{ft}$. The sediment-rock contact was abrupt, unlike the gradational contact observed in the Grant 1 borehole. This rhyolitic unit, beginning at $94 \mathrm{ft}$ and continuing to $215 \mathrm{ft}$, was a gray to bluegray rhyolite flow and tuff. Green muds and gray tuff with quartz bipyramids occurred from 150-215 ft. From 215-245 $\mathrm{ft}$, the borehole penetrated a rhyolite flow with hydrothermal alteration and prominent quartz bipyramids. From $245-270 \mathrm{ft}$, the borehole penetrated a zone of chaotic tuff beneath which 
Table 12. General stratigraphy and lithology for the B944 Grant borehole, Yellowstone National Park, Wyoming.

\begin{tabular}{|c|c|c|}
\hline Depth (feet) & Description & Comments \\
\hline $0-55$ & Pale-brown, pebble-rich sand & $\begin{array}{l}\text { Glacially faceted gravels present; hammer bit used until } 430 \text { feet, then tricone bit from } \\
430 \text { feet to base of hole }\end{array}$ \\
\hline $94-215$ & Dark-gray to blue-gray rhyolite and tuff & $\begin{array}{l}\text { Vitrophyric at } 94 \text { feet with } 1 \mathrm{gal} / \mathrm{min} \text { flow; glassy from } 120-145 \text { feet; quartz bipyramids } \\
\text { at } 150 \text { feet; green mud, gray tuff, and pale-green tuff observed from } 155-215 \text { feet }\end{array}$ \\
\hline $245-270$ & Chaotic tuff & $30 \mathrm{gal} / \mathrm{min}$ flow; green mud and probable metal sulfides at 270 feet \\
\hline $270-430$ & Rhyolite and tuff & $\begin{array}{l}\text { Glassy at } 345-350 \text { feet; bipyramidal quartz at } 415 \mathrm{feet} \text {; metal sulfides at } 385-400 \text { and } \\
429 \mathrm{feet} \text { green mud in rock at } 429 \mathrm{feet} ; 100 \mathrm{gal} / \mathrm{min} \text { at } 270 \mathrm{feet} ; 1-3 \mathrm{gal} / \mathrm{min} \text { at } 400 \\
\text { feet; } 35 \mathrm{gal} / \mathrm{min} \text { at } 420 \text { feet }\end{array}$ \\
\hline $430-505$ & Gray rhyolite and welded tuff & $100 \mathrm{gal} / \mathrm{min}$ at $430 \mathrm{feet} ; 200 \mathrm{gal} / \mathrm{min}$ at $435 \mathrm{feet}$; greater than $300 \mathrm{gal} / \mathrm{min}$ from $435-505$ \\
\hline
\end{tabular}

occurred another rhyolite flow and tuff to a depth of $430 \mathrm{ft}$. From $430 \mathrm{ft}$ to the bottom of the hole $(505 \mathrm{ft})$, the borehole penetrated a gray rhyolite flow and welded tuff. The downhole changes in lithology described above are associated with changing water production at boundaries between ash-flow tuffs and zones of increased fracture permeability.

\section{Geochemical Analysis of Cuttings}

As in the Grant 1 borehole, the REE geochemistry of the B944 Grant borehole samples from $105-230 \mathrm{ft}$ is similar to the REE geochemistry of the Tuff of Bluff Point (fig. 20). At 260-265 $\mathrm{ft}$ the REE geochemistry differs from the upper units within the B944 Grant borehole. This brecciated rhyolitic unit plots between the Tuff of Bluff Point and Dry Creek flow reference samples (fig. 21). Continued work on the brecciated rhyolite at $260-265 \mathrm{ft}$ is worthwhile with respect to Christiansen's (2001) hypothesis that the Tuff of Bluff Point was "an explosive, late-stage eruption from the Dry Creek vent." From 270-500 ft, the REE geochemistry of the samples is similar to the Tuff of Bluff Point and the upper units in the borehole. On the basis of the geochemistry, the B944 Grant borehole penetrated a sequence of ash-flow tuffs and breccia associated with the formation of the West Thumb caldera.

\section{Water Chemistry}

Eight water samples were collected during the drilling of the B944 Grant borehole from the following depths in feet below land surface: 95, 208, 265, 286, 395, 420, 430, and 505 . Generally, most constituents (bicarbonate, fluoride, chloride, sulfate, potassium, and sodium) did not show consistent changes or trends with depth (appendix 2). Stable-isotope values $\left(\delta \mathrm{D},-142\right.$ to $-146 \%$ and $\delta^{18} \mathrm{O},-19.1$ to $-19.2 \%$ ) are similar to values reported for precipitation throughout the region ( $\delta \mathrm{D},-115$ to $-153 \%$ and $\delta^{18} \mathrm{O},-15.2$ to $-20.2 \%$ ) (Rye and Truesdell, 1993; Kharaka and others, 2002) and are lighter than values of samples from Yellowstone Lake $(\delta \mathrm{D}$, $-124 \%$ and $\delta^{18} \mathrm{O},-16 \%$ ). Water sampled at $95 \mathrm{ft}$ below land surface had a tritium concentration of 7.87 TU. Water sampled at four other depths also were tritiated with a concentration of about $1 \mathrm{TU}$.

\section{Drilling Notes}

Drilling notes and geophysical logs for the B944 Grant borehole can be found at ftp://borehole.unavco.org/pub/borehole/B944/. Drilling began on July 16, 2008, and ceased on July 26, 2008, at a depth of $505 \mathrm{ft}$, with a measured bottom hole temperature of $34.8^{\circ} \mathrm{C}$. Major water production zones are shown in table 13.

Table 13. Major water production zones and temperature in the B944 Grant borehole, Yellowstone National Park, Wyoming.

\begin{tabular}{|c|c|c|c|c|}
\hline Date & $\begin{array}{c}\text { Time } \\
\text { (Mountain } \\
\text { Daylight Time) }\end{array}$ & $\begin{array}{l}\text { Depth } \\
\text { (feet) }\end{array}$ & $\begin{array}{l}\text { Discharge } \\
\text { (gallons per } \\
\text { minute) }\end{array}$ & $\begin{array}{c}\text { Temperature } \\
\text { (degrees } \\
\text { Celsius) }\end{array}$ \\
\hline July 26,2008 & $10: 38$ & 420 & 35 & 32.2 \\
\hline July 26, 2008 & $11: 55$ & 430 & 100 & 33.4 \\
\hline July 26,2008 & $13: 21$ & 435 & 200 & 35.0 \\
\hline July 26, 2008 & $17: 32$ & 505 & $>300$ & 34.8 \\
\hline
\end{tabular}




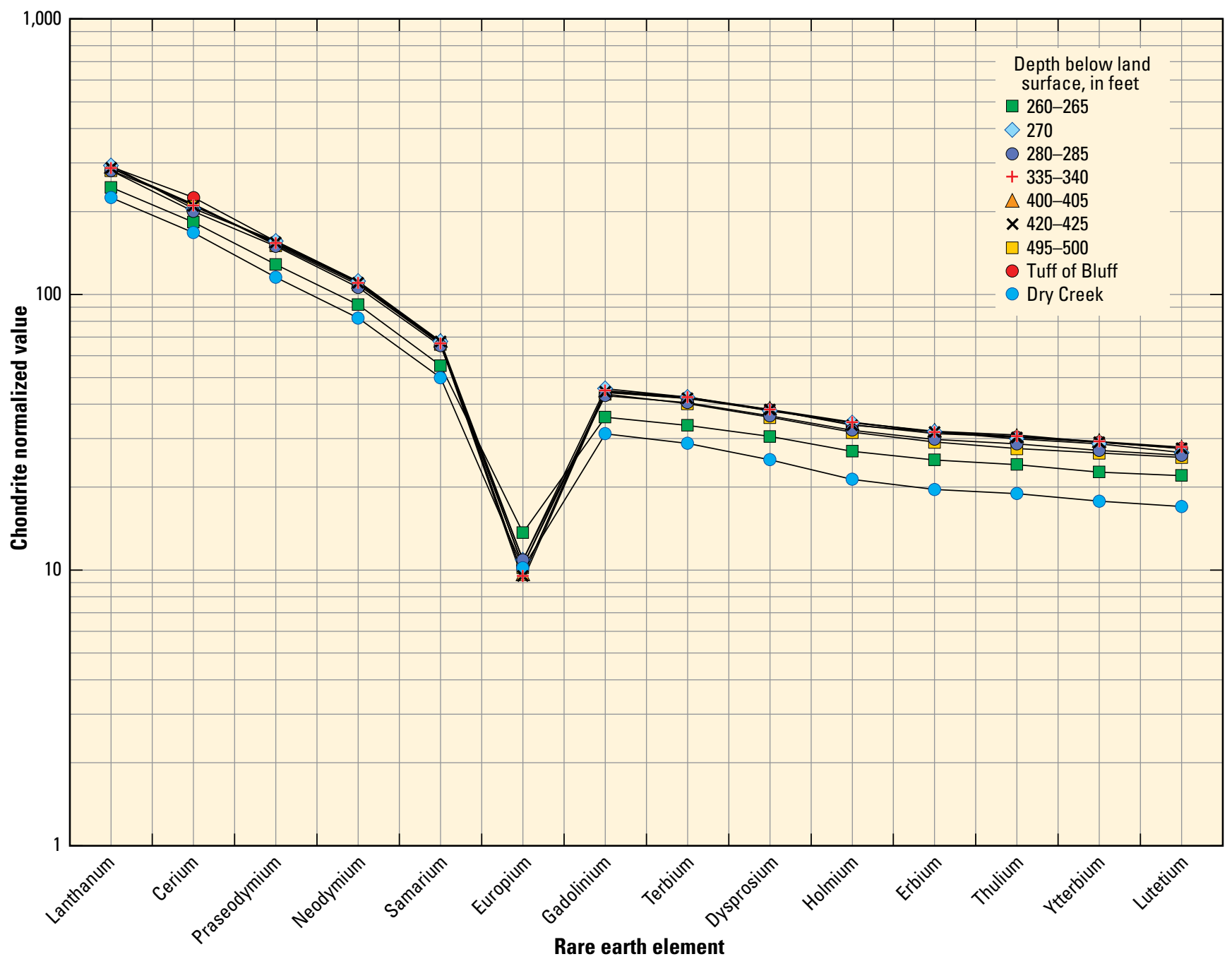

Figure 21. Rare earth element chemistry using chondrite normalized values of Boynton (1985) for selected depths in the lower part of the B944 Grant borehole and for reference samples from the Tuff of Bluff Point (Tuff of Bluff) and Dry Creek flow (Dry Creek), Yellowstone National Park, Wyoming.

\section{B945 Panther Creek Borehole}

\section{Location}

The B945 Panther Creek borehole is located south of Mammoth Hot Springs (fig. 22). An NPS service road that provides non-public access to water intake facilities heads west from the main Mammoth-Norris road and terminates near the B945 Panther Creek borehole.

\section{General Geology}

The area between Norris Junction and Mammoth Hot Springs is an active zone of Quaternary faulting with episodes of basaltic and rhyolitic volcanic activity outside the Yellowstone caldera. Near the B945 Panther Creek borehole, rocks related to the first and third Yellowstone volcanic cycles (the 2.1 million-year old Huckleberry Ridge Tuff and the 639,000-year old LCT), Absaroka volcanism, and basaltic volcanic eruptions have been mapped. The Panther Creek vent occurs near the B945 Panther Creek borehole. On the basis of observations during drilling, it is likely that episodic volcanic activity alternated with episodes of sedimentation possibly associated with late Quaternary glaciations of the Yellowstone Plateau.

A long history of relevant scientific thought and geologic research exists regarding the area surrounding the B945 Panther Creek borehole. As early as 1851, Bunsen introduced the concept of mixed lava flows (Wilcox, 1999). Early researchers (Iddings, 1899; Fenner, 1938; Wilcox, 1944) attempted to describe and explain their observations of the mixed rhyolite-basalt lava flows. The general stratigraphy and lithologies discussed by previous researchers (Boyd, 1961; Pierce, 1973; Christiansen, 2001; Bennett, 2006) provided an initial assessment of stratigraphy during the drilling of the B945 Panther Creek borehole. A USGS bedrock geologic map (U.S. Geological Survey, 1972) shows the following Quaternary volcanic units: the $639,000 \pm 2,000$-year old LCT-B, 


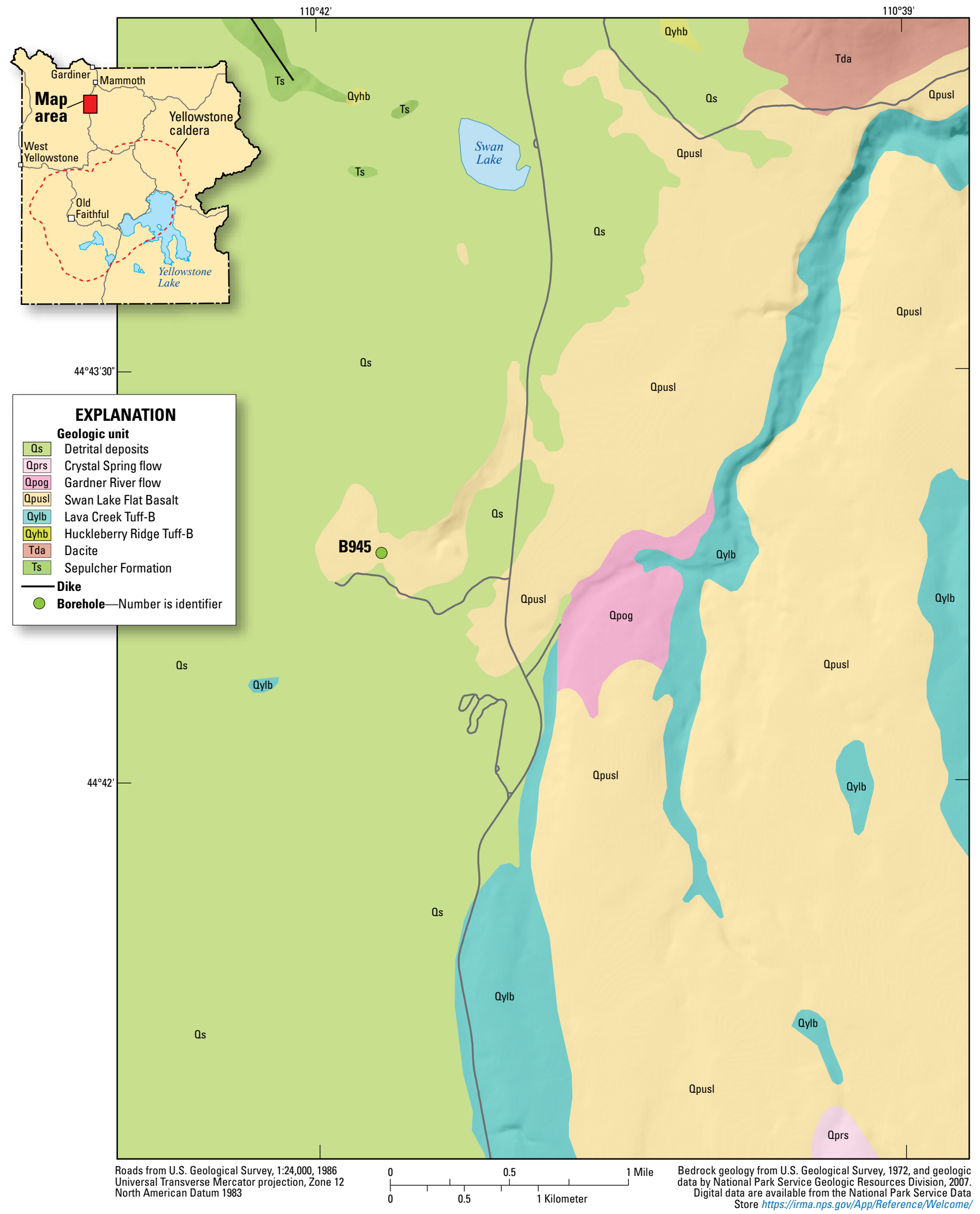

Figure 22. Bedrock geology in the vicinity of the B945 Panther Creek borehole, Yellowstone National Park, Wyoming. 
the $254,000 \pm 12,000$-year old to $108,000 \pm 15,000$-year old Swan Lake Flat Basalt, the 301,000-year old Gardner River mixed lava flow, and the $80,000 \pm 3,000$-year old Crystal Spring flow (refer to Obradovich, 1992; Nastanski and Spell, unpublished data, 2004, in Christiansen and others, 2007; and Christiansen and others, 2007, for numerical ages). Pierce (1973) mapped the surficial geology of the area and provided a glacial geologic context for understanding the interbedded sediments and basalts encountered during the drilling of the B945 Panther Creek borehole. From surface investigations, Bennett (2006) documented three episodes of basaltic activity at the Panther Creek vent: (1) an eruptive phase that produced agglutinate and red-brown scoria, (2) a second phase that produced flow-banded lava and a lava lake, and (3) a third phase that also produced red-brown scoria. Obradovich (1992), Bennett (2006), and Abedini and others (2007) dated the following episodes of volcanic activity for the Swan Lake Flat basalts: $590,000 \pm 56,000$ years, $254,000 \pm 12,000$ years, $204,000 \pm 31,000$ years, $174,000 \pm 46,000$ years, and $108,000 \pm 15,000$ years. Research regarding the Gardner River mixed lava flows (Wilcox, 1944; Struscaker, 1978; Pritchard, 2011; Pritchard and Larson, 2012; Pritchard and others, 2013) also provided geologic information for understanding the geochemistry and stratigraphy of the B945 Panther Creek borehole. In particular, Wilcox's (1944) mapping of the Gardner River mixed lavas and observations that basaltic lava was chilled against rhyolitic lava provides a basis for understanding the basal unit in the B945 Panther Creek borehole.

\section{Stratigraphy}

The B945 Panther Creek borehole encountered a series of basalt flows interbedded with sediments and a basal rhyolite flow (table 14). The uppermost basalt (15-75 ft) flowed over gravels containing subrounded tuff and faceted Flathead Sandstone, indicating a former, possibly glaciated, land surface. The basaltic unit from 90-310 ft covered an approximately 45 - $\mathrm{ft}$ thick fining-upward sequence of sediments from 310-355 ft. Approximately $115 \mathrm{ft}$ of vesicular and scoriaceous basalt (355-470 ft) covers a rhyolitic mixed lava flow at $490 \mathrm{ft}$. From approximately $470-515 \mathrm{ft}$, the drill cuttings had fragments of black vesicular lava mixed with pink-gray rhyolite. The geologic contacts between sediments and basalt or basalt and rhyolite are permeable fluid-flow boundaries.

\section{Geochemical Analysis of Cuttings}

The REE geochemistry of the B945 Panther Creek borehole cuttings is consistent with mixed basalt-rhyolites along the Mammoth-Norris corridor (fig. 23). The REE curve for the uppermost basalt at $50-55 \mathrm{ft}$ differs from the basalts at 155-160, 240-245, and 450-455 ft. The REE curve for the basalt at $50-55 \mathrm{ft}$ is most similar to the REE basalt reference sample (PCV SC2) from Sheepeater Cliff (fig. 23; table 2). Bennett's (2006) REE geochemistry for Swan Lake Flat basalts (samples YSLF-03-11 and YSLF-03-13) also is similar to the REE geochemistry of basalts from the B945 Panther Creek borehole. Although the REE geochemistry of a Gardner River rhyolite (GR-3-R) is similar to the basal rhyolite at $490-495 \mathrm{ft}$, it is intriguing that the Grizzly Lake REE curve (GL-4-R) is more similar to the 490-495-ft REE curve than the rhyolites from proximal outcrops of the Gardner River mixed lavas and its volcanic vent. Additional petrologic and geochemical work may provide an explanation for why the Grizzly Lake REE curves are most similar to the rhyolite flow at $490-495 \mathrm{ft}$.

Geochemical analyses of major elements by XRF (this study) and data from Pritchard (2011) provide additional information regarding the stratigraphic units within the B945 Panther Creek borehole. A major element plot of iron oxide $(\mathrm{FeO})$ versus silicon dioxide $\left(\mathrm{SiO}_{2}\right)$ shows the bimodal nature of stratigraphic units in the B945 Panther Creek borehole (fig. 24). The B945 borehole basalts plot at the upper left of the graph, and the basal rhyolite flow plots at the lower right. The basal rhyolite flow also plots near the Gardner River rhyolite flow (samples GR-3-R and GR-2-R in Pritchard, 2011) and the Grizzly Lake rhyolite flow (samples GL-5-L, GL-4-R, and GL-5-R in Pritchard, 2011). Samples from Sheepeater Cliff and the Panther Creek vent (PCV in table 2; fig. 24, PCV CJ) are similar to the basalt encountered at 50-55 ft in the B945 Panther Creek borehole. The Gardner River basalts (Pritchard, 2011, GR-1-B, GR-2-B, GR-3-B, and GR-3-2-B) and Grizzly Lake basalts (Pritchard, 2011, GL-4-B and GL-5-B) plot between the B945 Panther Creek borehole basalts and the basal rhyolite flow. On the basis of the geochemistry, the B945 Panther Creek borehole penetrated basalts and rhyolites representing bimodal volcanism between Mammoth Hot Springs and Norris Junction.

Table 14. General stratigraphy and lithology for the B945 Panther Creek borehole, Yellowstone National Park, Wyoming. [gal/min, gallons per minute]

\begin{tabular}{|c|c|c|}
\hline Depth (feet) & Description & Comments \\
\hline $0-15$ & Fill & Mixture of rock types \\
\hline $15-75$ & Basalt flow & $35 \mathrm{gal} / \mathrm{min}$ at $65 \mathrm{feet}$ \\
\hline $75-90$ & Gravels and mud & Subrounded clasts of tuff and faceted Flathead Sandstone; collapsing hole; flowing artesian at $100 \mathrm{gal} / \mathrm{min}$ \\
\hline $90-310$ & Basalt flows & Tricone bit; pale, red-brown clay at $120-130$ feet; basalt from $90-155,155-235$, and $235-310$ feet \\
\hline $310-355$ & Gravels, brown mud, silt & Hole collapsing; yellow-brown water at 315 feet; silt at $345-350$ feet; mud at $350-355$ feet \\
\hline $355-470$ & Basalt flow & Medium-gray, vesicular and scoriaceous \\
\hline $470-515$ & Rhyolite flow & Fragments of black vesicular lava mixed with pink-gray rock \\
\hline
\end{tabular}




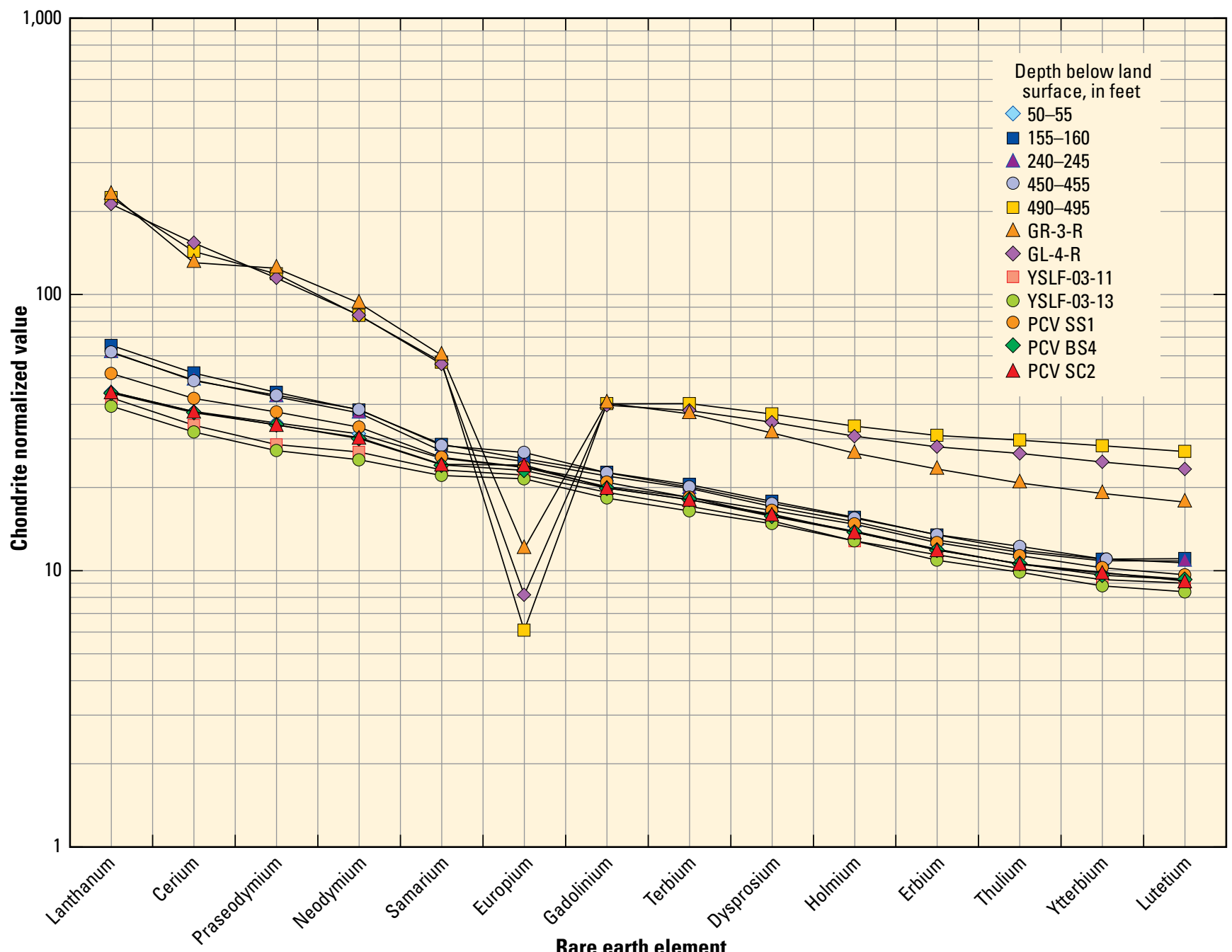

Figure 23. Rare earth element chemistry using chondrite normalized values of Boynton (1985) for selected depths in the B945 Panther Creek borehole and for selected reference samples from the Panther Creek vent (this study; PCV SS1, PCV BS4, and PCV SC2), the Swan Lake Flat Basalt (Bennett, 2006; YSLF-03-11 and YSLF-03-13), and the Gardner River and Grizzly Lake rhyolite flows (Pritchard, 2011; GR-3-R and GL-4-R), Yellowstone National Park, Wyoming.

\section{Water Chemistry}

Water samples were collected and analyzed from 85,310 , 455, and $515 \mathrm{ft}$ below land surface in the B945 Panther Creek borehole (appendix 2). Additional samples were collected at 400 and $475 \mathrm{ft}$, but these samples were not analyzed because the field parameter values were about the same as those for the sample from $455 \mathrm{ft}$. There are minor changes in water chemistry with depth for a number of constituents (appendix 2). Alkalinity concentrations in water from this borehole were higher than in water from any of the other boreholes, ranging from 292-330 milligrams per liter $(\mathrm{mg} / \mathrm{L})$. Stable-isotope values ( $\delta \mathrm{D},-140$ to $-150 \%$ and $\delta^{18} \mathrm{O},-18.7$ to $-19.9 \%$ ) are similar to values reported for precipitation throughout the region (Kharaka and others, 2002). At $310 \mathrm{ft}$, the tritium concentration was $8.1 \mathrm{TU}$, and water samples from 455 and $515 \mathrm{ft}$ had concentrations of 0.0 and $0.2 \mathrm{TU}$, respectively.

\section{Drilling Notes}

Drilling notes and geophysical logs for the B945 Panther Creek borehole can be found at ftp://borehole.unavco.org/pub/ borehole/B945. Drilling began on August 5, 2008, and ceased on August 12, 2008, at a depth of $515 \mathrm{ft}$ with a bottom hole temperature of $14.3^{\circ} \mathrm{C}$ measured on August 11, 2008. Major water production zones are shown in table 15.

Drillers pumped cement into the borehole multiple times, attempting to stop water production and collapse at the bottom of the hole. PBO field personnel determined that this borehole was not suitable for strainmeter installation. 


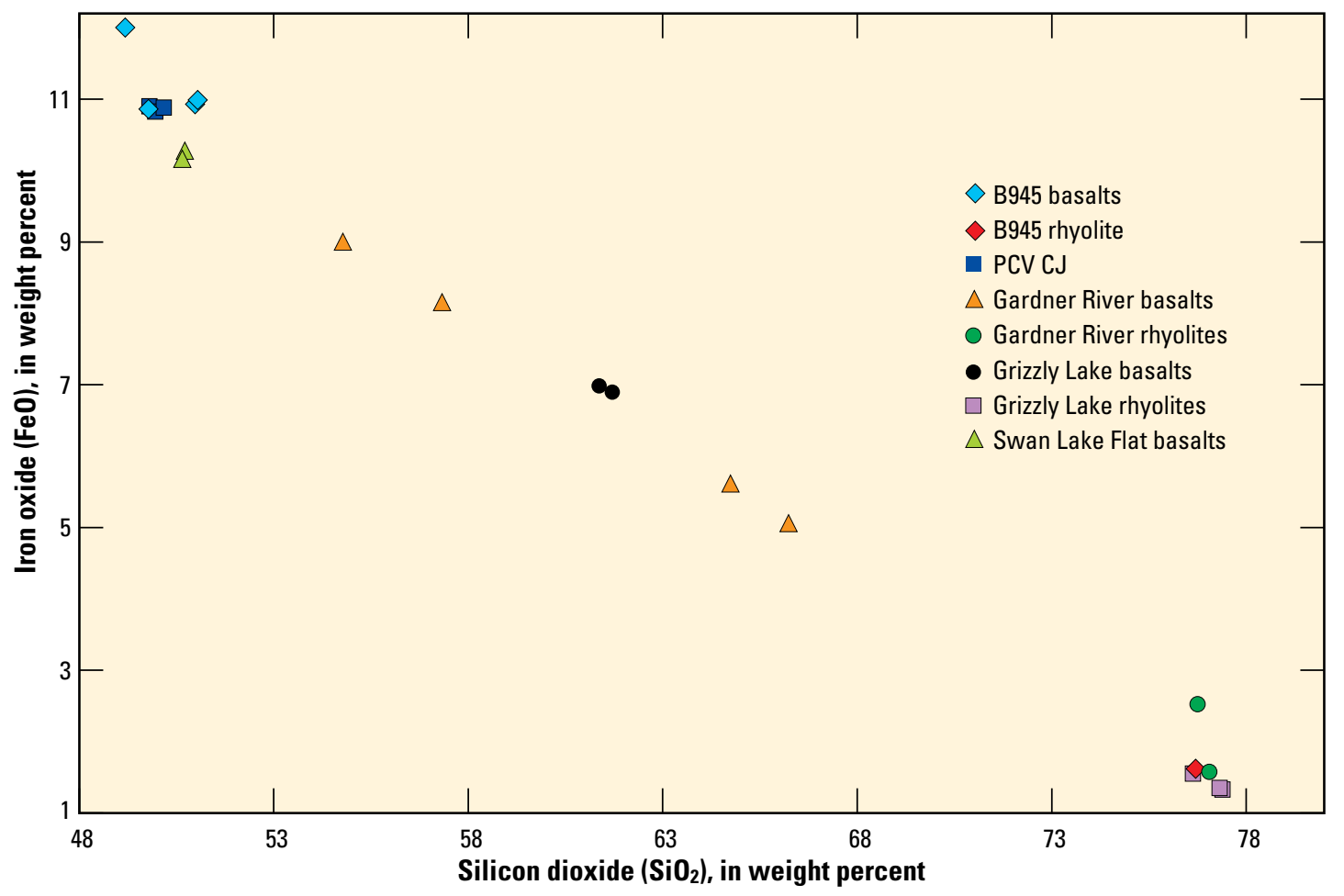

Figure 24. Concentrations, in weight percent, of iron oxide $(\mathrm{Fe} 0)$ versus silic on dioxide $\left(\mathrm{SiO}_{2}\right)$ for $\mathrm{B} 945$ Panther Creek borehole samples and samples from the Panther Creek vent (PCV CJ), and reference samples from Pritchard (2011) for Gardner River rhyolites (GR-2-R and GR-3-R), Gardner River basalts (GR-1-B, GR-2-B, GR-3-B, and GR-3-2-B), Grizzly Lake rhyolites (GL-5-L and GL-4-R), Grizzly Lake basalts (GL-4-B and GL-5-B), and Swan Lake Flat basalts.

Table 15. Major water production zones and temperature in the B945 Panther Creek borehole, Yellowstone National Park, Wyoming.

\begin{tabular}{|c|c|c|c|c|}
\hline Date & $\begin{array}{c}\text { Time } \\
\text { (Mountain } \\
\text { Daylight Time) }\end{array}$ & $\begin{array}{l}\text { Depth } \\
\text { (feet) }\end{array}$ & $\begin{array}{c}\text { Discharge } \\
\text { (gallons per } \\
\text { minute) }\end{array}$ & $\begin{array}{c}\text { Temperature } \\
\text { (degrees } \\
\text { Celsius) }\end{array}$ \\
\hline August 6, 2008 & Not noted & 75 & 75 & NM \\
\hline August 6, 2008 & $17: 30$ & 155 & 55 & NM \\
\hline August 10, 2008 & $16: 00$ & 377 & 23 & 12.0 \\
\hline August 11, 2008 & $10: 38$ & 451 & 175 & 11.3 \\
\hline August 12, 2008 & $14: 47$ & 495 & 150 & NM \\
\hline
\end{tabular}




\section{Summary}

In 2007 and 2008, seven boreholes ranging from about 200 to 800 feet (ft) in depth, were drilled in and adjacent to the Yellowstone caldera in Yellowstone National Park as part of the National Science Foundation funded Earthscope Plate Boundary Observatory. Five of the seven boreholes were equipped with strainmeters, downhole seismometers, and tiltmeters. This report presents results of stratigraphy based upon field observations and borehole cuttings, geochemical analyses of cuttings, with an emphasis on rare earth elements, and water-quality analyses from selected zones in the boreholes. The study focused on data collected during the drilling or immediately following drilling of the boreholes.

Results from field lithologic observations and preliminary interpretations of geochemistry data based on analysis of cuttings samples from the boreholes are as follows:

1. The B205 Norris borehole was drilled through the Gibbon River flow, and the Lava Creek Tuff B and A members (LCT-B and LCT-A) to a depth of $515 \mathrm{ft}$ and a bottom hole temperature of $66.9{ }^{\circ} \mathrm{C}$. Water flow occurred at major boundaries between lithologies and fractured zones within the LCT. Future petrologic and geochemical work may provide additional information about the initial LCT assessment for this borehole.

2. The B206 Canyon borehole was drilled through glacial sediments, the Hayden Valley flow, a transition zone, and probably the Canyon flow to a depth of $400 \mathrm{ft}$ and a bottom hole temperature of $81.2{ }^{\circ} \mathrm{C}$. At depth there are high temperatures and geothermal gases (greater than 60-percent carbon dioxide and 21.5 parts per million hydrogen sulfide) yet there is no surface expression of the hydrothermal fluids in the grassy meadow surrounding the borehole.

3. The B207 Madison borehole was drilled through the Nez Perce Creek flow and probably the upper LCT-A member to a depth of $691 \mathrm{ft}$ and a bottom hole temperature of $29.7^{\circ} \mathrm{C}$. Future petrologic and geochemical research may enhance our understanding of the LCT within the borehole.

4. The B208 Lake borehole was drilled through approximately $195 \mathrm{ft}$ of sediments and $400 \mathrm{ft}$ of rhyolite flows (West Thumb flow) and tuff (Tuff of Bluff Point) associated with the formation of the West Thumb caldera. The borehole terminated at a depth of about $800 \mathrm{ft}$ after drilling through almost $200 \mathrm{ft}$ of tuffaceous sediment with euhedral bipyramidal quartz and aerodynamically shaped glass. Bottom hole temperature was $19.6^{\circ} \mathrm{C}$.

5. The Grant 1 borehole was drilled through approximately $50 \mathrm{ft}$ of sediments and approximately $150 \mathrm{ft}$ of the Tuff of Bluff Point. High temperatures at the base of the borehole $\left(92.0^{\circ} \mathrm{C}\right.$ at $\left.206 \mathrm{ft}\right)$ precluded the installation of instruments and the hole was abandoned.

6. The B944 Grant borehole was drilled through approximately $100 \mathrm{ft}$ of sediments and nearly $400 \mathrm{ft}$ of tuffs and rhyolite (Tuff of Bluff Point) associated with the formation of the West Thumb caldera. Bottom hole temperature was $34.8^{\circ} \mathrm{C}$. Water was produced at permeable boundaries between rhyolitic units.
7. The B945 Panther Creek borehole was drilled through a sequence of basalts, sediments, and a basal rhyolite flow to a depth of $515 \mathrm{ft}$ and a bottom hole temperature of $14.3^{\circ} \mathrm{C}$. The intervening sediments highlight the episodic nature of bimodal volcanism at the Panther Creek vent. Fluid flow occurred along permeable boundaries between the sediments and basalts, or between the basal and underlying rhyolite flow.

8 . Results of analyses of water samples collected from boreholes varied with depth and temperature, with increasing concentrations at greater depths and temperatures. Stableisotope values were generally within the range of precipitation values reported for the Yellowstone region. Most of the water samples from the boreholes were tritiated and tritium concentrations generally decreased with depth.

\section{Acknowledgments}

The authors greatly appreciate the numerous individuals and organizations that made this work possible. The National Science Foundation Earthscope Program provided funding for the drilling of the boreholes and installation of strainmeters. Robert Smith, University of Utah, Department of Geology and Geophysics, obtained funding for the borehole strainmeter project in Yellowstone National Park (YNP) and selected drilling locations. Discussions with Jacob Lowenstern and Robert Christiansen, U.S. Geological Survey (USGS), assisted the senior author's understanding of Yellowstone's rhyolites and geologic history. USGS reviewers Kathryn Watts and Melissa Masbruch provided comments that improved this report. A collaborative agreement (RM-CESU J1580100365) between the YNP Geology Program and Washington State University's GeoAnalytical Laboratory provided funding for geochemical analyses (XRF and ICP-MS) of cuttings from the boreholes. In particular, John Wolff, GeoAnalytical Laboratory, supported this collaborative agreement. Charles Knaack, GeoAnalytical Laboratory, provided quality ICP-MS analyses and Laureen Wagoner, GeoAnalytical Laboratory, provided timely answers and information. Beginning in 2007, Daniel Mahony, YNP Geology staff, assisted with washing cuttings for all boreholes. During 2008, volunteers with the Geological Society of America GeoCorps program (Dianah Grub Wheeler and Catherine Foley) also washed and organized cuttings from some boreholes. From 2010-12, YNP Geology volunteer and summer intern, Laura Bueter, assisted with the organization of cuttings and collecting samples from the Panther Creek-Sheepeater Cliffs area. During 2013, Casper College and University of Wyoming geology students (Allan Fraser, Annette Hein, Lewis Hein, Adam Johnson, Jason Whitmore, Evan Soderberg, and Emily Sundell) volunteered to describe borehole cuttings and examine thin sections derived from grain mounts. From 2012-13, Adriana Garcia with the USGS Utah Water Science Center (UWSC) organized spreadsheets and produced initial graphs for visualization of borehole geochemistry. Lawrence Spangler, USGS UWSC, is thanked for his editorial review of this report. Finally, our appreciation goes to the crew at Tacoma Pump and Drilling for communicating their onsite observations while safely drilling the boreholes. 


\section{References}

Abedini, A.A., Calvert, A.T., and Hurwitz, S., 2007, New $40 \mathrm{Ar} / 39 \mathrm{Ar}$ age determinations of basalts from the Yellowstone Plateau volcanic field: American Geophysical Union Fall Meeting 2007 Proceedings, abstract \#V53B-1321.

Barringer, J.L., and Johnsson, P.A., 1996, Theoretical considerations and a simple method for measuring alkalinity and acidity in low-pH waters by Gran titration: U.S. Geological Survey Water-Resources Investigations Report 89-4029, $36 \mathrm{p}$.

Bayer, R., Schlosser, P., Bonisch, G., Rupp, H., Zaucker, F., and Zimmek, G., 1989, Performance and blank components of a mass spectrometric system for routine measurement of tritium by the $3 \mathrm{He}$ ingrowth method: Sitzungberichte der Heidelberger Akademie der Wissenschaften, Mathematischnaturwissenschaftliche Klasse, 5, p. 241-279.

Bennett, K.M., 2006, Petrogenesis of Pleistocene basalts in the Norris-Mammoth corridor, Yellowstone National Park: University of Nevada, Las Vegas, M.S. Thesis, 137 p.

Bindeman, I.N., and Valley, J.W., 2001, Low- $\delta 180$ rhyolites from Yellowstone-Magmatic evolution based on analyses of zircons and individual phenocrysts: Journal of Petrology, v. 42 , no. 8 , p. $1494-1517$.

Bindeman, I.N., Valley, J.W., Wooden, J.L., and Persing, H.M., 2001, Post-caldera volcanism-In situ measurement of $\mathrm{U}-\mathrm{Pb}$ age and oxygen isotope ratio in Pleistocene zircons from Yellowstone caldera: Earth and Planetary Science Letters, v. 189, p. 197-206.

Blank, Jr., H.R., Prostka, H.J., Keefer, W.R., and Christiansen, R.L., 1974, Geologic map of the Frank Island quadrangle, Yellowstone National Park: U.S. Geological Survey Geologic Quadrangle GQ-1209, scale 1:62,500.

Boyd, F.R., 1961, Welded tuffs and flows in the rhyolite plateau of Yellowstone Park: Geological Society of America Bulletin, v. 72, p. 387-426.

Boynton, W.V., 1985, Cosmochemistry of the rare earth elements-Meteorite studies, chap. 3 of Henderson, P., ed., Rare earth element geochemistry (Developments in Geochemistry 2): Amsterdam, Elsevier, p. 115-152.

Brinton, T.I., Antweiler, R.C., and Taylor, H.E., 1995, Method for the determination of dissolved chloride, nitrate, and sulfate in natural water using ion chromatography: U.S. Geological Survey Open-File Report 95-426A, 16 p.

Christiansen, R.L., 1974, Geologic map of the West Thumb quadrangle, Yellowstone National Park: U.S. Geological Survey Geologic Quadrangle GQ-1191, scale 1:62,500.
Christiansen, R.L., 1975, Geologic map of the Norris Junction quadrangle, Yellowstone National Park: U.S. Geological Survey Geologic Quadrangle GQ-1193, scale 1:62,500.

Christiansen, R.L., 1984, Yellowstone magmatic evolutionIts bearing on understanding large-volume explosive volcanism, in Explosive volcanism, its inception, evolution, and hazards: Washington D.C., National Academy of Sciences, p. $84-95$.

Christiansen, R.L., 2001, The Quaternary and Pliocene Yellowstone Plateau volcanic field of Wyoming, Idaho, and Montana: U.S. Geological Survey Professional Paper 729-G, $145 \mathrm{p}$.

Christiansen, R.L., and Blank, Jr., H.R., 1974, Geologic map of the Madison Junction quadrangle, Yellowstone National Park: U.S. Geological Survey Geologic Quadrangle GQ-1190, scale 1:62,500.

Christiansen, R.L., and Blank, Jr., H.R., 1975, Geologic map of the Canyon Village quadrangle, Yellowstone National Park: U.S. Geological Survey Geologic Quadrangle GQ-1192, scale 1:62,500.

Christiansen, R.L., Lowenstern, J.B., Smith, R.B., Heasler, Henry, Morgan, L.A., Nathenson, Manuel, Mastin, L.G., Muffler, L.J.P., and Robinson, J.E., 2007, Preliminary assessment of volcanic and hydrothermal hazards in Yellowstone National Park and vicinity: U.S. Geological Survey Open-File Report 2007-1071, 94 p.

Cox, E.R., 1973, Water resources of Yellowstone National Park, Wyoming, Montana and Idaho: U.S. Geological Survey Open-File Report 73-53, 161 p.

Fenner, C.N., 1936, Bore-hole investigation in the Yellowstone Park: Journal of Geology, v 44, p. 225-315.

Fenner, C.N., 1938, Contact relations between rhyolite and basalt on the Gardner River, Yellowstone National Park: Geological Society of America Bulletin 49, p. 1441-1484.

Garbarino, J.R., and Taylor, H.E., 1979, An inductive-coupled plasma atomic-emission spectrometric method for routine water quality testing: Applied Spectroscopy 33(3), p. $220-226$.

Girard, G., and Stix, J., 2009, Magma recharge and crystal mush rejuvenation associated with early post-collapse Upper Basin Member rhyolites, Yellowstone caldera, Wyoming: Journal of Petrology, v. 50, p. 2095-2125, doi:10.1029/2008JB005791.

Harris, R.N., and Chapman, D.S., 2007, Stop-go temperature logging for precision applications: Geophysics, v. 72, p. 119-123, doi:10.1190/1.2734382. 
Iddings, J.P., 1899, The rhyolites, in Hauge, A., Iddings, J.P., Weed, W.H., Walcott, C.D., Girty, G.H., Stanton, T.W., and Knowlton, F.H., eds., Geology of the Yellowstone National Park, Part II: U.S. Geological and Geographical Survey of the Territories, Twelfth annual report, part 2, Yellowstone National Park, 503 p.

Johnson, D.M., Hooper, P.R., and Conrey, R.M., 1999, XRF analysis of rocks and minerals for major and trace elements on a single low dilution Li-tetraborate fused bead: GeoAnalytical Laboratory, Washington State University, Advances in X-ray Analysis, Proceedings, v. 41, p. 843-867.

Kharaka, Y.K., Thordsen, J.J., and White, L.D., 2002, Isotope and chemical compositions of meteoric and thermal waters and snow from the greater Yellowstone National Park region: U.S. Geological Survey Open-File Report 02-194, $75 \mathrm{p}$.

Lanphere, M.A., Champion, D.E., Christiansen, R.L., Izett, G.A., and Obradovich, J.D., 2002, Revised ages of tuffs of the Yellowstone Plateau volcanic field-Assignment of the Huckleberry Ridge Tuff to a new geomagnetic polarity event: Geological Society of America Bulletin 114, p. 559-568.

Marfil, S., and Maiza, P., 2012, Geochemistry of hydrothermal alteration in volcanic rocks, chap. 3 of Panagiotaras, Dionisios, ed., Geochemistry-Earth's system processes: ISBN: 978-953-51-0586-2, InTech, available at http://www.intechopen.com/books/geochemistry-earth-s-system-processes/ geochemistry-of-hydrothermal-alteration-in-volcanic-rocks, p. 39-60.

McCleskey, R.B., Ball, J.W., Nordstrom, D.K., Holloway, J.M., and Taylor, H.E., 2005, Water chemistry data for selected springs, geysers, and streams in Yellowstone National Park, Wyoming, 2001-2002: U.S. Geological Survey Open-File Report 2004-1316, 94 p.

McCleskey, R.B., Nordstrom, D.K., and Naus, C.A., 2004, Questa baseline and pre-mining ground-water-quality investigation. 16. Quality assurance and quality control for water analyses: U.S. Geological Survey Open-File Report 2004-1341, 105 p.

National Park Service Geologic Resources Division, 2007, Digital compilation of USGS 15-minute bedrock geology, 1:62,500 scale, available via National Park Service Data Store at http://www.nps.gov/gis/data_info/.

Obradovich, J.D., 1992, Geochronology of the late Cenozoic volcanism of Yellowstone National Park and adjoining areas, Wyoming and Idaho: U.S. Geological Survey OpenFile Report 92-408, 45 p.
Pierce, K.L., 1973, Surficial geologic map of the Mammoth quadrangle and part of the Gardiner quadrangle, Yellowstone National Park, Wyoming and Montana: U.S. Geological Survey Miscellaneous Geologic Investigations Map I-641, scale 1:62,500.

Piper, D.Z., and Bau, M., 2013, Normalized rare earth elements in water, sediments, and wine-Identifying sources and environmental redox conditions: American Journal of Analytical Chemistry, v. 4, no. 10A, p. 69-83, doi: 10.4236/ajac.2013.410A1009.

Pritchard, C.J., 2011, Post-caldera volcanism in Yellowstone National Park-Petrogenesis of the intracaldera Upper Basin Member rhyolite and extra-caldera mingled magma: Pullman, Washington State University, Ph.D. dissertation, 339 p.

Pritchard, C.J., and Larson, P.B., 2012, Genesis of the postcaldera eastern Upper Basin Member rhyolites, Yellowstone, WY - From volcanic stratigraphy, geochemistry, and radiogenic isotope modeling: Contributions to Mineralogy and Petrology, Springer Verlag, 164, p. 205-228.

Pritchard, C.J., Larson, P.B., Spell, T.L., and Tarbert, K.D., 2013, Eruption-triggered mixing of extra-caldera basalt and rhyolite complexes along the East Gallatin-Washburn fault zone, Yellowstone National Park, WY: Lithos, 175-176, p. 163-177.

Révész, Kinga, and Coplen, T.B., 2008a, Determination of the $\delta\left({ }^{2} \mathrm{H} /{ }^{1} \mathrm{H}\right)$ of water-RSIL lab code 1574 , chap. C1 of Révész, Kinga, and Coplen, T.B., eds., Methods of the Reston Stable Isotope Laboratory: U.S. Geological Survey Techniques and Methods 10-C1, 27 p.

Révész, Kinga, and Coplen, Tyler B., 2008b, Determination of the $\delta\left({ }^{18} 0 /{ }^{16} 0\right)$ of water-RSIL lab code 489 , chap. C2 of Révész, Kinga, and Coplen, Tyler B., eds., Methods of the Reston Stable Isotope Laboratory: U.S. Geological Survey Techniques and Methods, 10-C2, 28 p.

Richmond, G.M., 1973, Surficial geologic map of the West Thumb quadrangle, Yellowstone National Park: U.S. Geological Survey Miscellaneous Geologic Investigations Map I-643, scale 1:62,500.

Richmond, G.M., 1974, Surficial geologic map of the Frank Island quadrangle, Yellowstone National Park, Wyoming: U.S. Geological Survey Miscellaneous Geologic Investigations Map I-642, scale 1:62,500.

Richmond, G.M., 1977, Surficial geologic map of the Canyon Village quadrangle, Yellowstone National Park: U.S. Geological Survey Miscellaneous Geologic Investigations Map I-652, scale 1:62,500. 
Richmond G.M., and Waldrop, H.A., 1975, Surficial geologic map of the Norris Junction quadrangle, Yellowstone National Park, Wyoming: U.S. Geological Survey Miscellaneous Geologic Investigations Map I-642, scale 1:62,500.

Rye, R.O., and Truesdell, A.H., 1993, The question of recharge to the geysers and hot springs of Yellowstone National Park: U.S. Geological Survey Open-File Report 93-384, 40 p.

Sass, J.H., Lachenbruch, A.H., Munroe, R.J., Greene, G.W., and Moses, T.H., Jr., 1971, Heat flow in the western United States: Journal of Geophysical Research, v. 76, p. 6376-6413.

Stookey, L.L., 1970, Ferrozine-A new spectrophotometric reagent for iron: Analytical Chemistry, v. 42, p. 779-781.

Struscaker, D.W., 1978, Mixed basalt-rhyolite assemblages in Yellowstone National Park: Missoula, University of Montana, M.S. Thesis, $112 \mathrm{p}$.

U.S. Geological Survey, 1972, Geologic map of Yellowstone National Park: U.S. Geological Survey Geologic Investigations Series Map I-711, scale 1:125,000.

Von Stauffenberg, J.C., 2015, Spatiotemporal evolution of the Lava Creek Tuff magma chamber in Yellowstone National Park-Implications for eruption triggering mechanisms from major and trace element zoning in feldspar: Pullman, Washington State University, M.S. Thesis, 212 p.
Waldrop, H.A., and Pierce, K.L., 1975, Surficial geologic map of the Madison Junction quadrangle, Yellowstone National Park: U.S. Geological Survey Miscellaneous Geologic Investigations Map I-651, scale 1:62,500.

Watts, K.E., Bindeman, I.N., and Schmitt, A.K., 2012, Crystalscale anatomy of a dying supervolcano-An isotope and geochronology study of individual phenocrysts from voluminous rhyolites of the Yellowstone caldera: Contributions to Mineralogy and Petrology, v. 164, p. 45-67.

White, D.E., Fournier, R., Muffler, L.P.J., and Truesdell, A.H., 1975, Physical results of research drilling in thermal waters of Yellowstone National Park, Wyoming: U.S. Geological Survey Professional Paper 892, $70 \mathrm{p}$.

Wilcox, R.A., 1999, The idea of magma mixing-History of a struggle for acceptance: Journal of Geology, v. 107, p. 421-432.

Wilcox, R.E., 1944, Rhyolite-basalt complex of Gardner River, Yellowstone National Park, Wyoming: Geological Society of America Bulletin 55, p. 1047-1080. 


\section{Appendix 1. Major and rare earth element analyses for selected samples of cuttings from boreholes drilled in 2007 and 2008 and for reference samples from selected volcanic units in Yellowstone National Park, Wyoming.}

Table A1-1. Rare earth element chemistry for cuttings samples from Earthscope Plate Boundary Observatory boreholes, Yellowstone National Park, Wyoming.

Table A1-2. Rare earth element chemistry for reference samples from mapped geologic units, Yellowstone National Park, Wyoming.

Table A1-3. Major- and trace-element chemistry for cuttings samples from Earthscope Plate Boundary Observatory boreholes, Yellowstone National Park, Wyoming.

Table A1-4. Major- and trace-element chemistry for reference samples from mapped geologic units, Yellowstone National Park, Wyoming.

\section{Appendix 2. Water-quality analyses for samples collected during the drilling of boreholes in 2007 and 2008 in Yellowstone National Park, Wyoming.}

Table A2-1. Field measurements and results of chemical analysis for major ions, trace elements, stable isotopes, and tritium for water samples collected from boreholes and selected other sites, 2007 and 2008, Yellowstone National Park, Wyoming. 



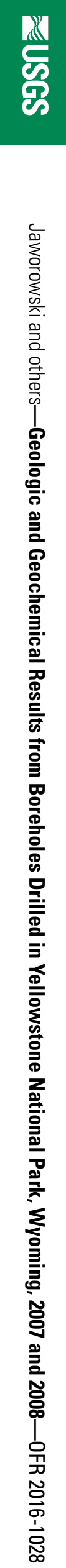